\title{
Geophysical Exploration in the Lautertal at the Combat Maneuver Training Center, Hohenfels, Germany
}

Energy Systems Division

Argonne National Laboratory

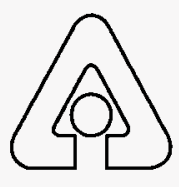

Operated by The University of Chicago, under Contract W-31-109-Eng-38, for the United States Department of Energy

DISTRIBUTION OE THIS DOCUMENT IS UNLIMITED TJ 


\section{Argonne National Laboratory}

Argonne National Laboratory, with facilities in the states of Illinois and Idaho, is owned by the United States Government, and operated by the University of Chicago under the provisions of a contract with the Department of Energy.

This technical memo is a product of Argonne's Energy Systems (ES) Division. For information on the division's scientific and engineering activities, contact:

Director, Energy Systems Division

Argonne National Laboratory

Argonne, llinois 60439-4815

Telephone (708) 252-3724

Presented in this technical memo are preliminary results of ongoing work or work that is more limited in scope and depth than that described in formal reports issued by the ES Division.

Publishing support services were provided by Argonne's Information and Publishing Division.

\section{Disclaimer}

This report was prepared as an account of work sponsored by an agency of the United States Government. Neither the United States Government nor any agency thereof, nor any of their employees, makes any warranty, express or implied, or assumes any legal liability or responsibility for the accuracy, completeness, or usefulness of any information, apparatus, product, or process disclosed, or represents that its use would not infringe privately owned rights. Reference herein to any specific commercial product, process, or service by trade name, trademark, manufacturer, or otherwise, does not necessarily constitute or imply its endorsement, recommendation, or favoring by the United States Government or any agency thereof. The views and opinions of authors expressed herein do not necessarily state or reflect those of the United States Government or any agency thereof.

Available to DOE and DOE contractors from the Office of Scientific and Technical Information, P.O. Box 62, Oak Ridge, TN 37831; prices available from (615) 576-8401.

Available to the public from the National Technical Information Service, U.S. Department of Commerce, 5285 Port Royal Road, Springfield, VA 22161. 


\section{DISCLAIMER}

Portions of this document may be illegible in electronic image products. Images are produced from the best available original document. 


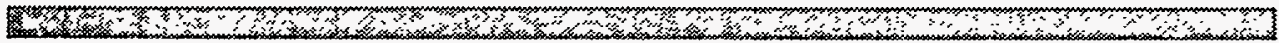

\section{Geophysical Exploration in the Lautertall at the Combat Maneuver Training Center, Hohenfels, Germany}

4 r m

by P.C. Heigold, M.D. Thompson, and H.M. Borden

Center for Environmental Restoration Systems, Energy Systems Division,

Argonne National Laboratory, 9700 South Cass Avenue, Argonne, Illinois 60439

October 1994

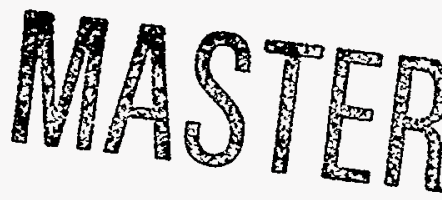

DISTRIBUTION OF THIS DOCUMENT IS UNLIMITED

Work sponsored by United States Department of Defense, United States Army, Europe, Combat Maneuver Training Center, Hohenfels, Germany 



\section{Contents}

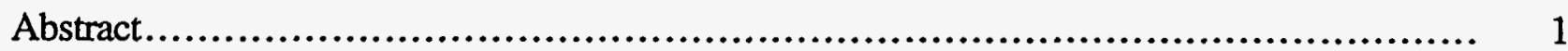

1 Introduction....................................................................... 1

2 Geological Setting..................................................................... 5

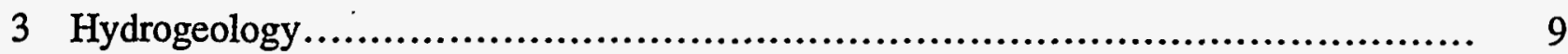

4 Geophysical Exploration ........................................................ 13

4.1 Land Surveying...................................................................... 13

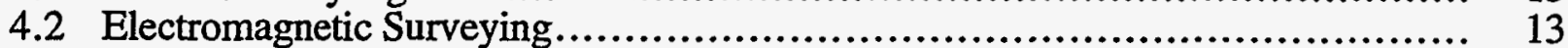

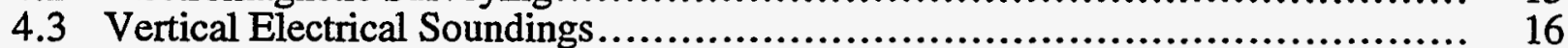

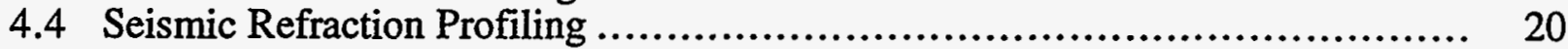

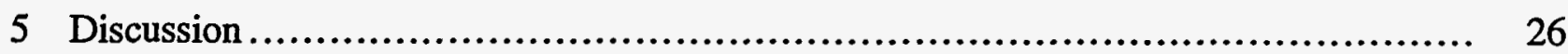

6 Conclusions and Recommendations ............................................ 28

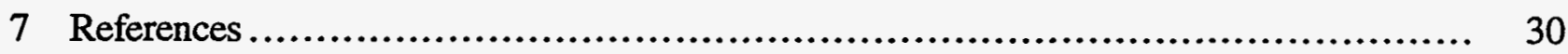

Appendix A: Data for the Geophysical Studies in the Lautertal.......................... 33

Appendix B: Visualizations of Some of the Results from the Geophysical Surveys in the Lautertal..

\section{Tables}

A.1 Surface Elevations in the Lautertal Study Area .................................. 35

A.2 Electromagnetic Surveying Data..................................................... 38

A.3 Results of Inversion of Vertical Electrical Sounding Data........................ 44

A.4 Results of Inversion of Seismic Refraction Profiling Data ....................... 55

\section{Figures}

1 Location of Hohenfels Training Area in Germany ............................... 2

2 Map of the Lautertal Study Area Covered by an Orthogonal Grid ................ 3

3 Geologic Map of Bavaria....................................................... 4

4 Geologic Map of the Lautertal Region.............................................. 6 


\section{Figures (Cont.)}

5 Columnar Section from the Earth's Surface to the Gamma-Zeta

Members of the Dogger Formation............................................. 7

6 Structure on the Top of the Dogger Formation ................................. 8

7 Drainage Basin of the Naab River ............................................. 11

8 Water-Table Elevations in Bavaria ............................................ 12

9 Surface Topography of the Lautertal Study Area................................... 14

10 Areal Distribution of Apparent Conductivity as Determined by

Electromagnetic Surveying with a 10-m Transmitter-Receiver Spacing............. 14

11 Areal Distribution of Apparent Conductivity as Determined by

Electromagnetic Surveying with a 20-m Transmitter-Receiver Spacing............. 15

12 Areal Distribution of Apparent Conductivity as Determined by

Electromagnetic Surveying with a 40-m Transmitter-Receiver Spacing............ 15

13 Frequency Distribution of the Resistivity of the Near-Surface Layers

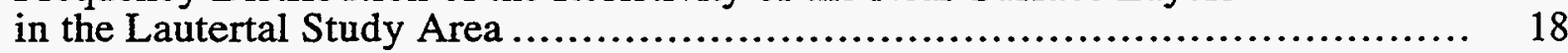

14 Resistivity Distribution Showing Locations Where Loam and

Loess Cover Alluvium and Colluvium in the Lautertal Study Area.............. 18

15 Resistivity Distribution Showing Locations Where Loam and

Loess Lie Directly on Bedrock Surface in the Lautertal Study Area .............. 19

16 Thickness of the Loam and Loess in the Lautertal Study Area .................... 20

17 Frequency Distribution of the Velocities of the Near-Surface

Deposits in the Lautertal Study Area.......................................... 22

18 Areal Distribution of the Velocities of the Alluvium and Colluvium

in the Lautertal Study Area ........................................................ 22

19 Areal Distribution of the Velocities of the Bedrock Surface in the

Lautertal Study Area ............................................................ 23

20 Thickness of the Alluvium and Colluvium in the Lautertal Study Area............ 24

21 Bedrock Topography in the Lautertal Study Area............................... 24

22 Cross Section of the Main North-South-Trending Bedrock

Channel in the Lautertal along Line 58 North................................ 25

23 Cross Section of the East-West-Trending Bedrock Channel in the

Lautertal along Line 13 East. 


\section{Figures (Cont.)}

B.1 Electrical Conductivity Distributions in the Lautertal as Determined by Electromagnetic Surveying

B.2 Shallow Geological Framework of the Lautertal as Determined by Vertical Electrical Soundings....

B.3 Surface Topography and Base of the Fine-Grained, Unconsolidated Surficial Deposits in the Lautertal............................................................... 71

B.4 Shallow Geological Framework of the Lautertal as Determined by Seismic Refraction Profiling 


\title{
Geophysical Exploration in the Lautertal at the Combat Maneuver Training Center, Hohenfels, Germany
}

by

P.C. Heigold, M.D. Thompson, and H.M. Borden

\begin{abstract}
Geophysical exploration was conducted in the Lautertal at the Combat Maneuver Training Center, Hohenfels, Germany, to determine the shallow geological framework of a typical dry valley in this karstic environment. The complementary methods of electromagnetic surveying, vertical electrical soundings, and seismic refraction profiling were successful in determining the depth and configuration of the bedrock surface, the character of the unconsolidated deposits resting on the bedrock surface, and the nature of the bedrock surface. Channels and other depressions in the bedrock surface are aligned with structurally induced fractures in the bedrock. The unconsolidated deposits consist of coarse alluvium and colluvium, which are confined to these channels and other depressions, and fine-grained loam and loess, which cover most of the Lautertal. Wide ranges in the electrical and elastic parameters of the bedrock surface are indicative of carbonate rock that is highly fractured and dissolved at some locations and competent at others. Most local groundwater recharge occurs in the uplands where the Middle Kimmeridge (Delta) Member of the Malm Formation (Jurassic) is widely exposed. These carbonate rocks are known to be susceptible to dissolution along the fractures and joints; thus, they offer meteoric waters ready access to the main shallow aquifers lower in the Malm Formation. These same rocks also form the bedrock surface below many of the dry valleys, but in the Lautertal, the infiltration of meteoric waters into the subsurface is generally impeded by the surficial layer of fine-grained loam and loess, which have low hydraulic conductivity. Further, the rocks of the Middle Kimmeridge Member appear to be closely associated with the localized occurrence of turbidity in such perennial streams as the Lauterach.
\end{abstract}

\section{Introduction}

The environmental management office at the Combat Maneuver Training Center, Hohenfels, Germany, would like to ensure that military impacts on local groundwater quality and flow are minimized or eliminated. In order to accomplish this goal, a valid model of the groundwater flow system, along with a geographic information system to facilitate data input and output, is needed for planning and response purposes. 
Conceptual and numerical groundwater flow models of the Combat Maneuver Training Center and its surroundings must be based on a thorough knowledge of geologic and hydrologic conditions in the Hohenfels region. Much of this information can be obtained through a series of basic geophysical and hydrogeological investigations.

Geophysical exploration was conducted in the Lautertal at the Combat Maneuver Training Center (Figures 1 and 2) to determine the shallow geological framework of a typical "dry" valley in this karstic environment. The term dry, as used here, implies well-drained without perennial streams. Knowledge of the shallow geological framework of these numerous dry valleys is essential to understanding the roles of these valleys in the shallow groundwater flow system.

Groundwater in the shallow aquifers of this region is highly susceptible to contamination from surficial sources as a result of the high degree of interdependency between surficial drainage and subsurface flow. Even the deeper, regional, water-supply aquifers are at risk from contamination unless they are separated from the shallow aquifers by geological units with very low hydraulic conductivities.

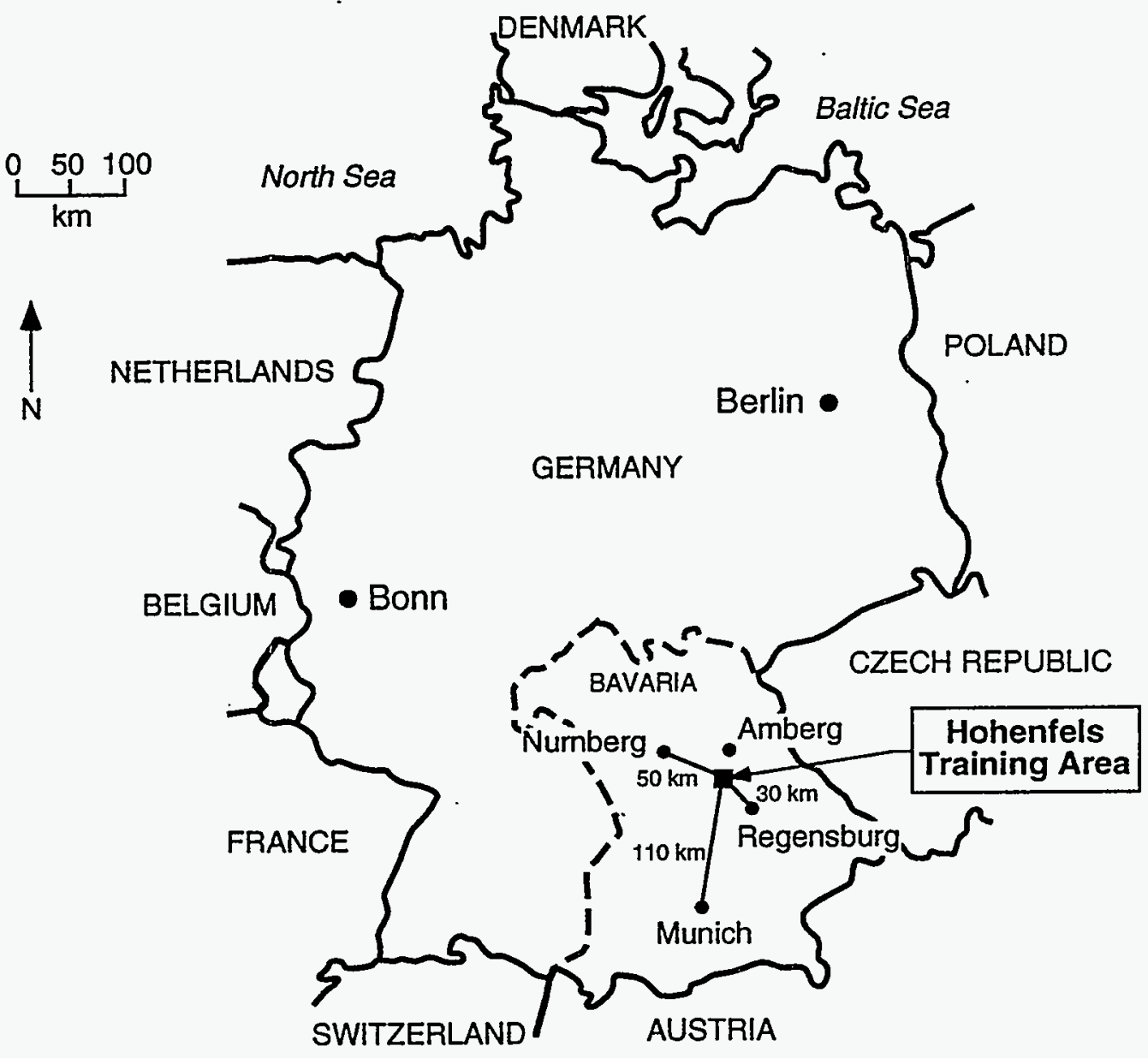

FIGURE 1 Location of Hohenfels Training Area in Germany 


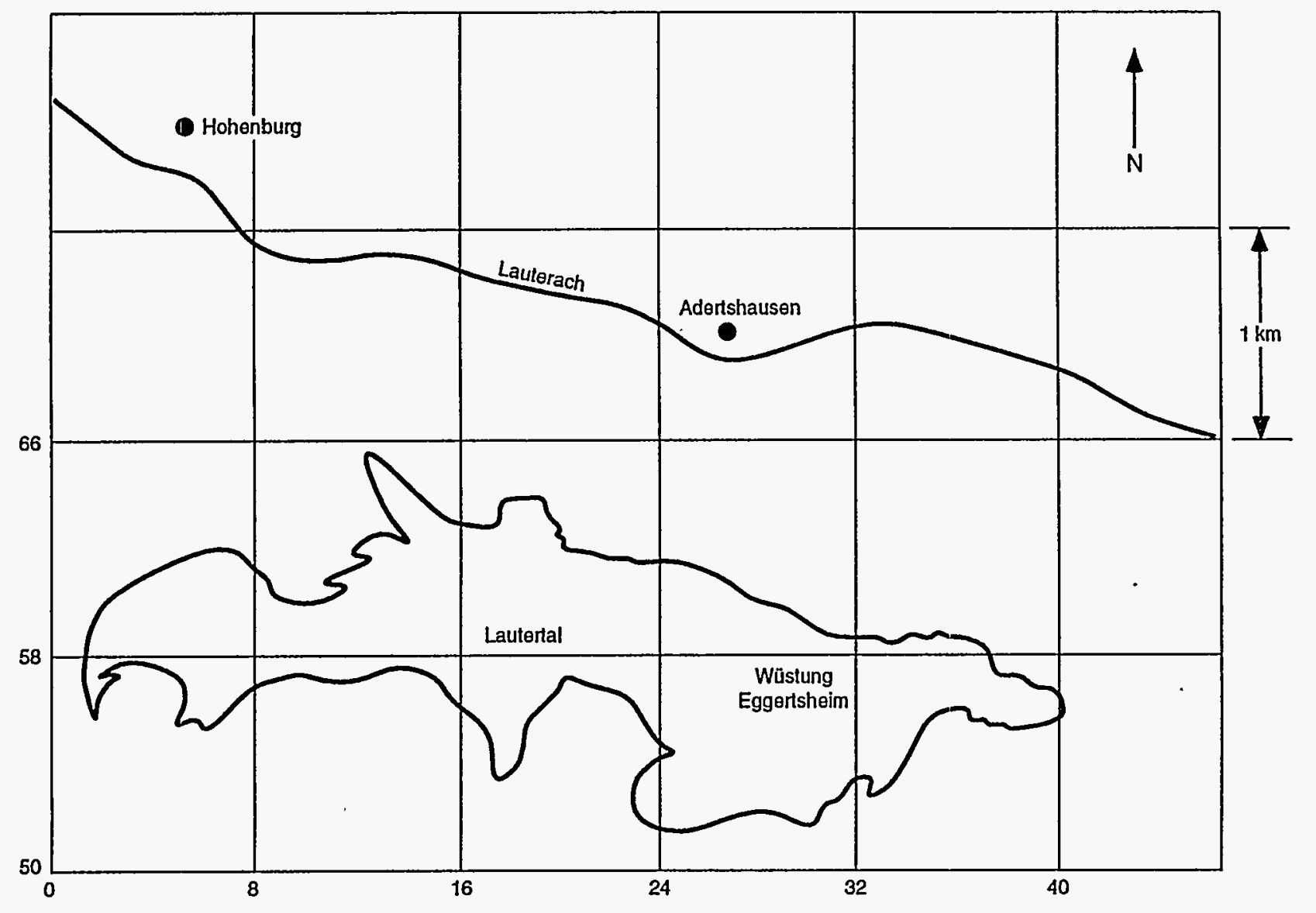

FIGURE 2 Map of the Lautertal Study Area Covered by an Orthogonal Grid

In the Hohenfels region, heavy rainfall is often immediately followed by localized occurrences of increasing turbidity in some perennial rivers and streams that are independent from tributary influences. This situation would suggest that residence time of water in the shallow aquifers is short and that pathways from points of recharge to points of discharge may be relatively simple.

Geophysical exploration in a well-developed karstic environment can be difficult. Interfaces between geological units can be quite irregular. Fracturing and dissolution of the carbonate rocks can, and often do, alter the magnitudes of geophysical parameters that are normally expected from these lithotypes. The success of a geophysical exploration program in such an environment depends on the selection of appropriate geophysical methods and the careful interpretation of data. Although individual methods may have shortcomings, the chosen methods must complement one another in such a way as to collectively provide diagnostic results.

A geophysical exploration program specifically designed for the Lautertal project consisted of electromagnetic surveying, vertical electrical soundings, and seismic refraction profiling. These geophysical techniques were chosen to provide information on the depth and configuration of the bedrock surface, the nature of the unconsolidated deposits resting on the bedrock surface, and the character of the bedrock. This information is required to create conceptual and numerical hydrogeological models of the groundwater flow system. 


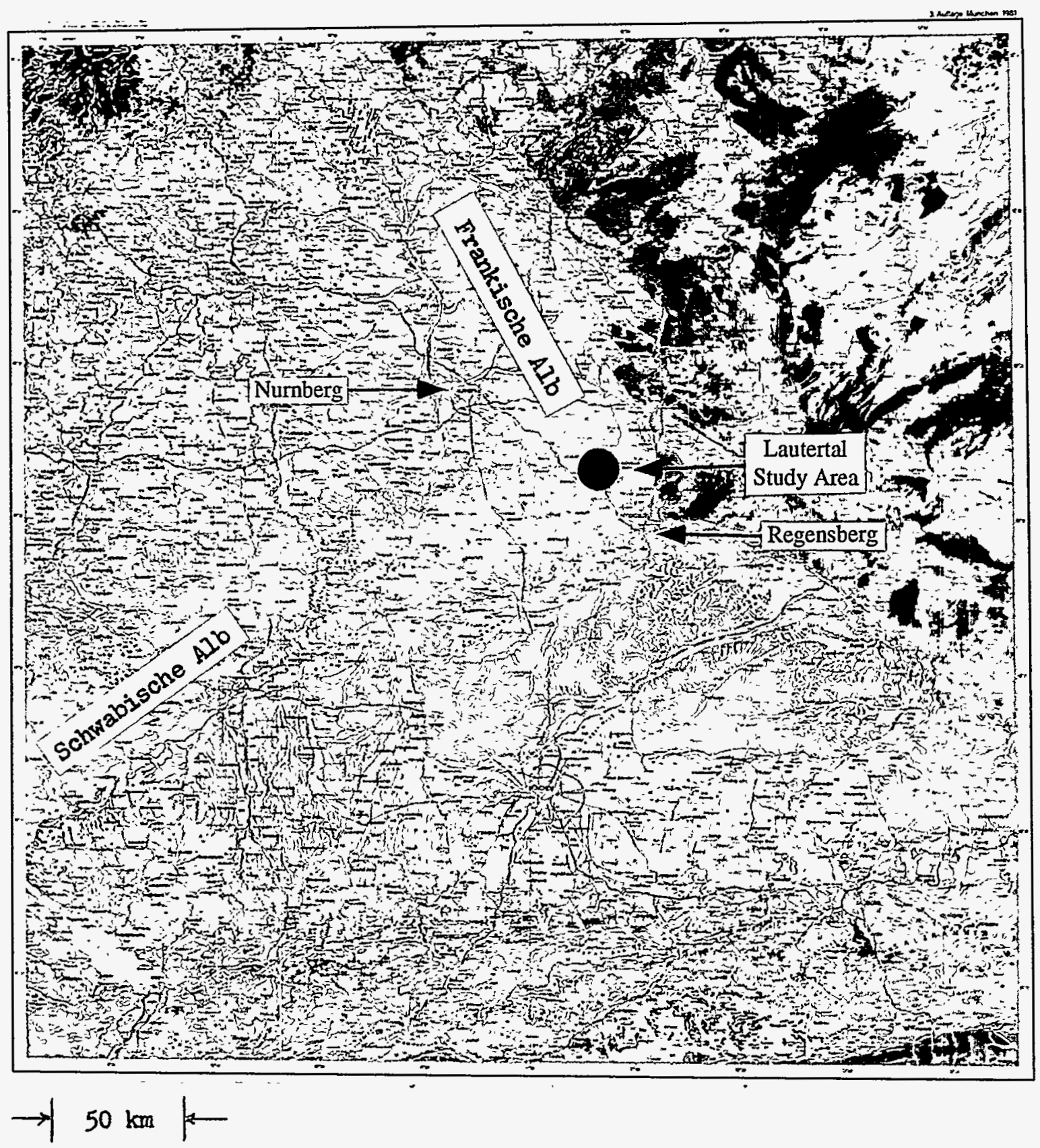

FIGURE 3 Geologic Map of Bavaria 


\section{Geological Setting}

The Lautertal study area is located in the southeastern part of the Frankische Alb, a continuation of the Schwabische Alb (Figure 3). In this region, the countless, forested, dolomitic knolls on the flanks of deep valleys like the Lautertal form an imposing karstic landscape. The upper bedrock units in the Lautertal are composed of reef dolomite and limestones of the Middle Kimmeridge (Delta) Member of the Malm Formation (Jurassic) (Meyer 1990) (Figures 4 and 5). Within the Lautertal, there are remnants of what are believed to be Upper Cretaceous rocks (Schutzfelsschichten or protective rock layers). These deposits are mainly fluvial, and they lie in channels and other depressions on the bedrock surface, the result of dissolution along joints and fractures that began early in Cretaceous time (Meyer 1990). Undifferentiated Pleistocene and Recent deposits, loam and loess over limestone and dolomitic rubble, blanket the Lautertal valley and its tributary valleys, except for a small area at the west end of the Lautertal where the Schutzfelsschichten is exposed. The erosion-resistant knolls that flank the Lautertal are composed of reef dolomite and layers of the Upper Kimmeridge (Epsilon) Member of the Malm Formation (Meyer 1990).

The varying resistance of the Malm to erosion and the susceptibility of this formation to dissolution have been cited as the factors responsible for the present topography in the Lautertal region (Meyer 1990). The thinly bedded facies of the Malm, a sequence of limestones and marly limestones that have been differentially dolomitized, is generally more resistant to erosion. The massive limestone facies, which consists primarily of dolomitized coralline reef with sponges and brachiopods, is more susceptible to dissolution. As in other karstic carbonate terrains in temperate climates, the occurrence of fractures is believed to contribute significantly to the development of dissolution features (Lattman and Parizek 1964).

Regionally, the Malm Formation rests on the Dogger Formation (Jurassic). The Dogger is composed mainly of sandstones, shales, and marls. The uppermost member of the Dogger Formation, the Zeta Member, contains the Ornaten clay. The Ornaten clay is important because it forms the lower confining layer of the Malm aquifer, the principal shallow aquifer in the region.

Bedrock strata in the Lautertal dip gently to the east, toward the Riedener-Kallmünzer Ast, a branch of the Frankische Mulde (trough) (Freyberg 1969) (Figure 6). There are no major faults or folds in the Lautertal region. Fuhrmann (1967) examined several small bedrock structures in the area, including some at nearby Stettkirchen, and concluded that the principal directions of fractures and joints in the bedrock are north-northeast and west-northwest. 


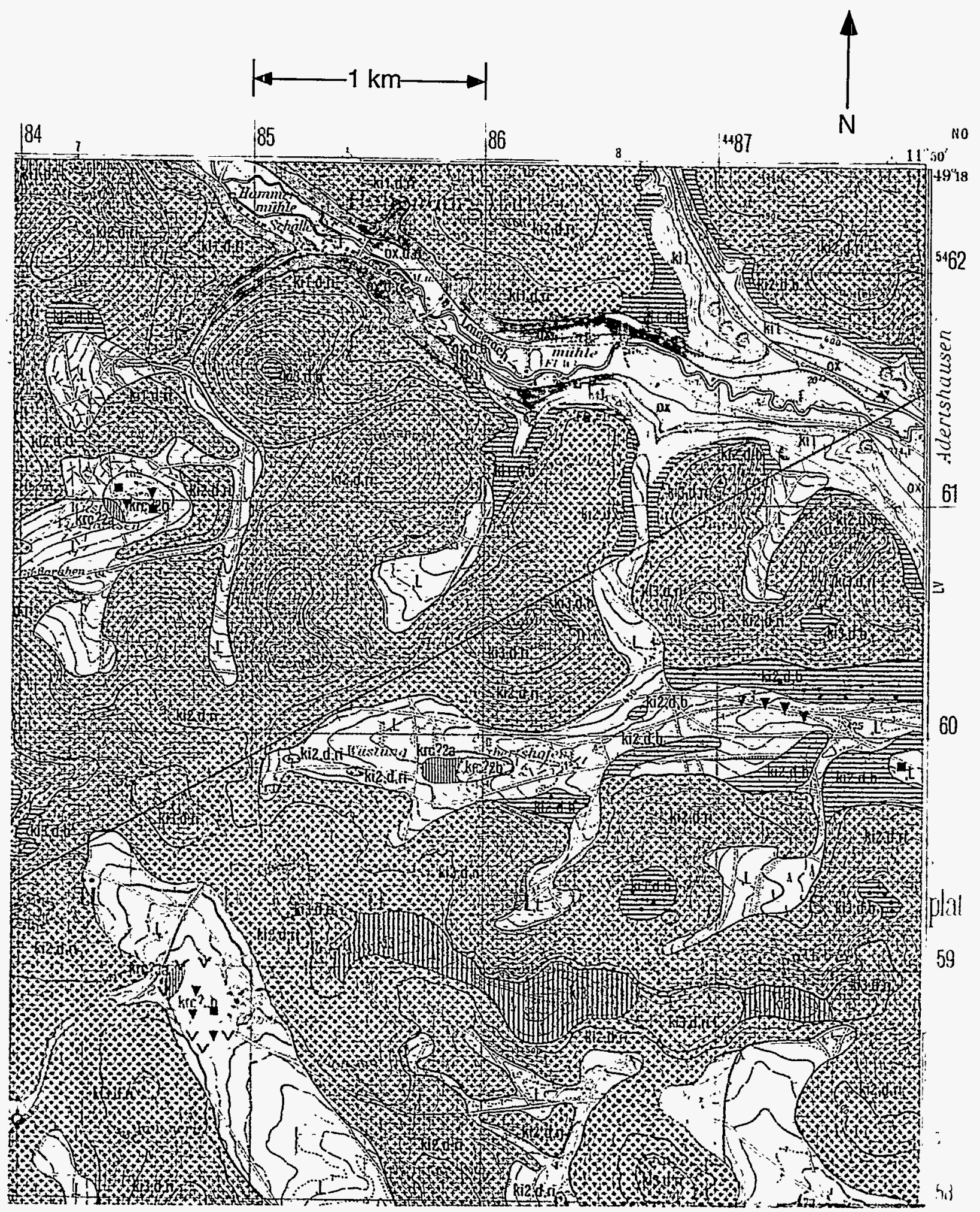

FIGURE 4 Geologic Map of the Lautertal Region (Velburg Quad) 


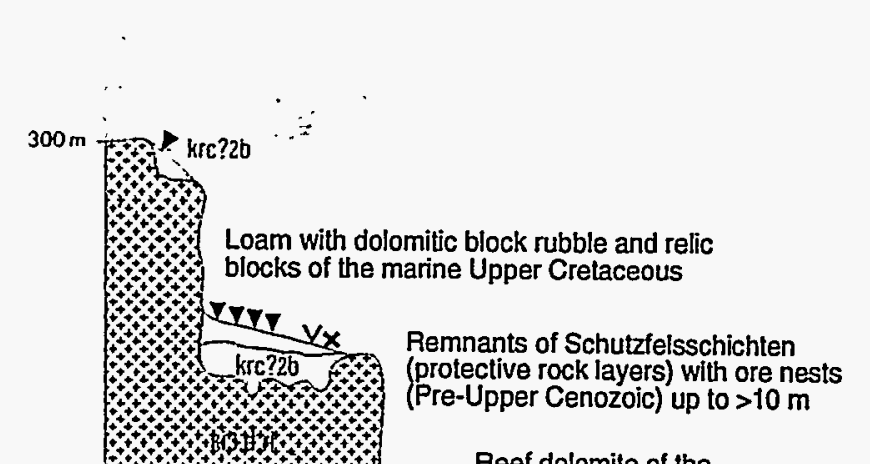

Reef dolomite of the

Upper Kimmeridge - layers
(Malm Epsilon) up to $50 \mathrm{~m}$

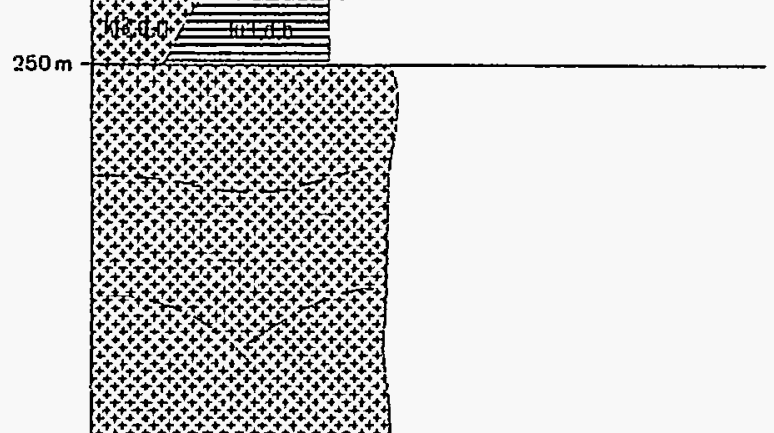

Reef dolomite of the

Middle Kimmeridge - layers

$200 \mathrm{~m}$

(Malm Delta) 70-90 m

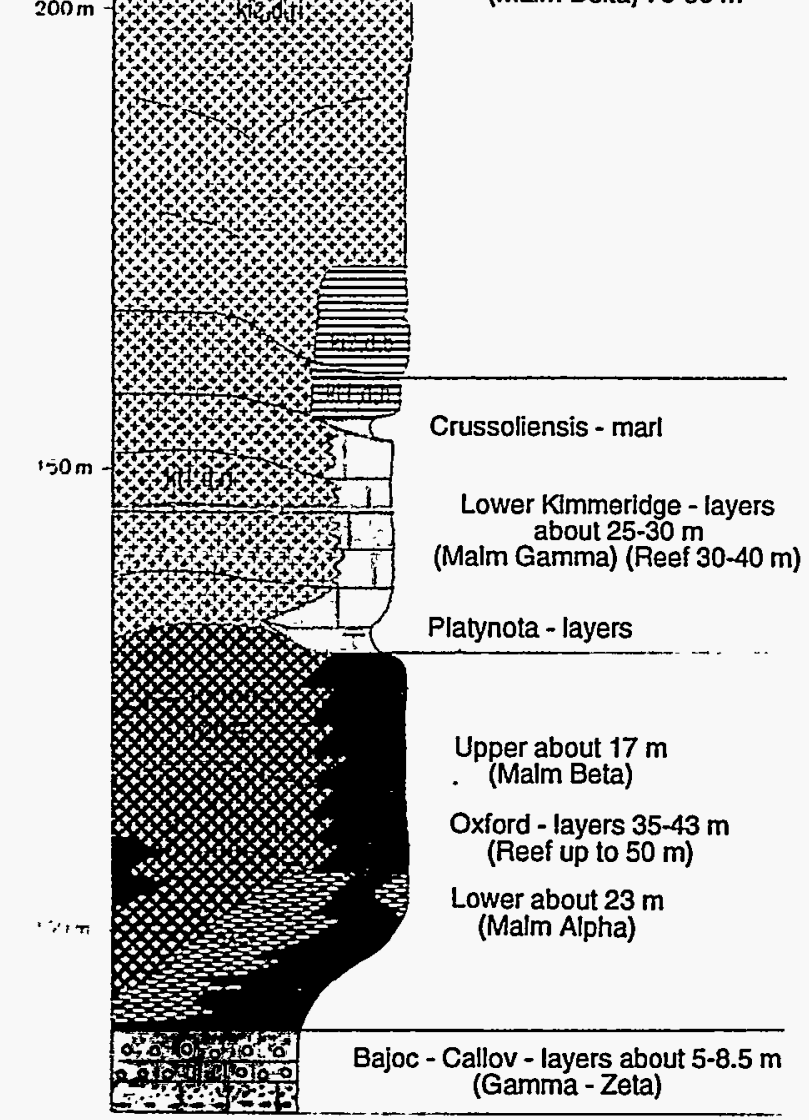

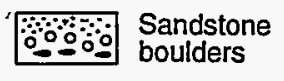

Bank limestone

Clay, marl, loam

00 Clay with ironstone geoids

FIGURE 5 Columnar Section from the Earth's Surface to the Gamma-Zeta Members of the Dogger Formation (Jurassic) 
(6961

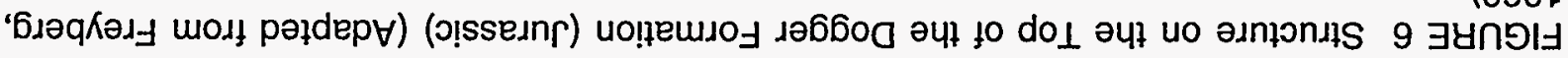

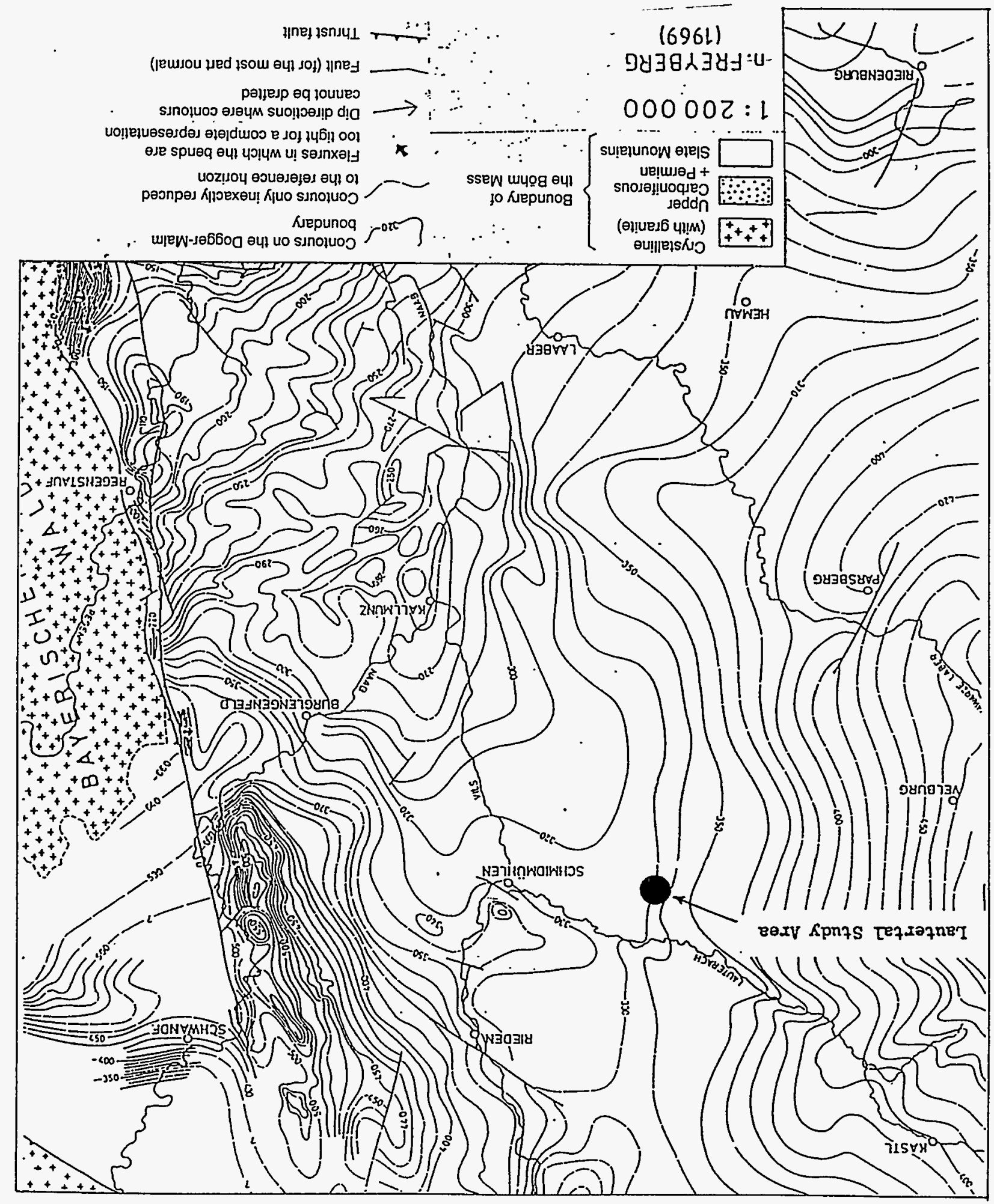




\section{Hydrogeology}

The hydrogeology of the Lautertal study area is typical of a karstic environment. The trellis/rectangular drainage pattern that has developed on the surface is indicative of structurally controlled topography and drainage (Figure 4). Valleys and ephemeral streams tend to form above solution-widened joints and fractures in the bedrock. Joints and fractures in the bedrock surface serve as receiving points for water and contaminants infiltrating through the vadose zone.

In such dry valleys as the Lautertal, where the joints and fractures at the bedrock surface have become sizable channels and depressions, the vadose zone may include surficial loam and loess, alluvium and colluvium, and a portion of the upper bedrock. The alluvial and colluvial deposits are a combination of the Schutzfelsschichten (Upper Cretaceous) and coarse Pleistocene and Recent deposits. The coarse deposits resting on the bedrock surface have hydraulic conductivities much greater than those of the fine-grained loam and loess. Still in the valley, but away from the channels and other depressions in the bedrock surface, the alluvial and colluvial deposits may be absent, and the vadose zone may include only surficial loam and loess and a portion of the upper bedrock. In the uplands, away from the valleys, the vadose zone consists of only the upper bedrock, which is exposed at the earth's surface.

The principal near-surface aquifer in the Lautertal region is a network of joints, fractures, and cavities in the carbonate Malm Formation (Jurassic). The joints, fractures, and cavities are the result of tectonic stresses and subsequent dissolution. In a region of moderate rainfall, the development of fracture porosity through solution occurs rapidly in the tens of meters immediately below the bedrock surface, where the groundwater flow system is open and accessible to rapid recharge. Rainfall and evaporation in the Lautertal region at the present time have been estimated to be approximately 700 and $480 \mathrm{~mm} / \mathrm{yr}$; respectively (Schoger 1992).

In places the Malm aquifer is confined (Ebasco-Dorch Consultants, Inc. 1990). Under these conditions, the upper confining layer consists of dense, dolomitic limestone, also of the Malm Formation. The lower confining layer is the Ornaten clay of the Zeta Member of the Dogger Formation. When the top of the Malm aquifer was breached during drilling at the Old Landfill about $4 \mathrm{~km}$ south of the Lautertal, the water rose in the well bores approximately $20 \mathrm{~m}$, indicating a very impermeable upper confining layer (Schoger 1992). In the area of the Old Landfill, the Malm aquifer was estimated to be $70-80 \mathrm{~m}$ thick, and the depth to the top of the aquifer was approximately $61 \mathrm{~m}$. Borings at the Old Landfill confirmed an exceptionally thick unsaturated zone above the Malm aquifer $(45-61 \mathrm{~m})$. There are reasons to believe that similar conditions exist in the Lautertal. The near-surface geology in the Lautertal is essentially the same as that at the Old Landfill. Unconsolidated deposits consisting of loam and loess over limestone and dolomitic rubble rest on carbonate rocks of the Middle Kimmeridge Member of the Malm Formation (Meyer 1990). Surface elevations at the Old Landfill are similar to those in the center of the Lautertal directly to the north. A water-table elevation map of Bavaria (Andres and Wirth 1985) shows similar elevations at both locations. 
The lowest surface elevations in the Lautertal are located in a north-south valley that transects the Lautertal near the western side of Wüstung Eggertsheim (Figure 2). Runoff of meteoric waters that do not infiltrate the vadose zone accumulate in this valley before flowing northward into the Lauterach. Some ponding occurs at localized low spots in the relatively impermeable, fine-grained surficial deposits.

The meteoric waters that infiltrate the vadose zone and ultimately find their way to the main Malm aquifer flow eastward and southeastward toward the Vils and Naab Rivers (Andres and Wirth 1985) (Figures 7 and 8). 


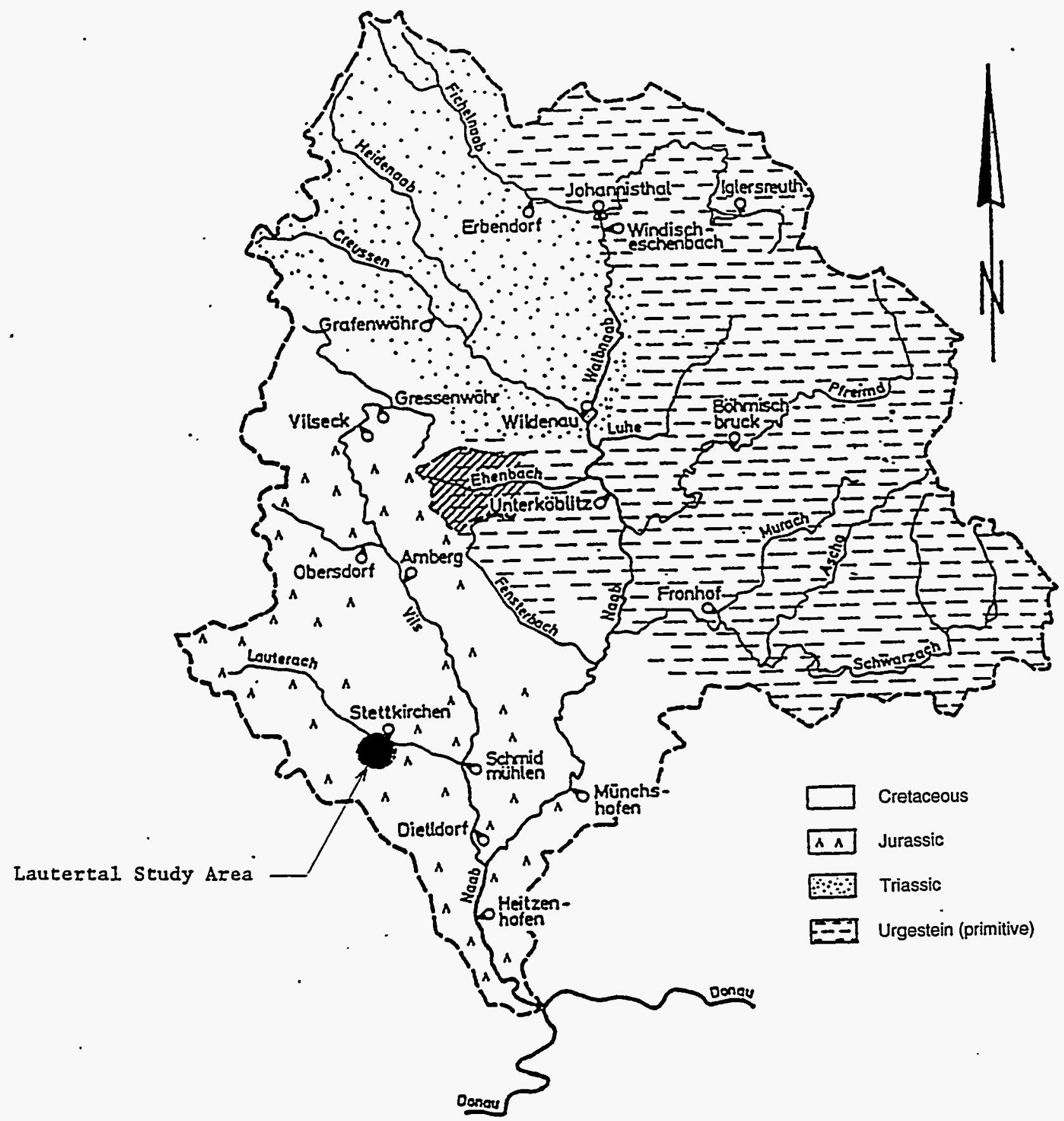

FIGURE 7 Drainage Basin of the Naab River 


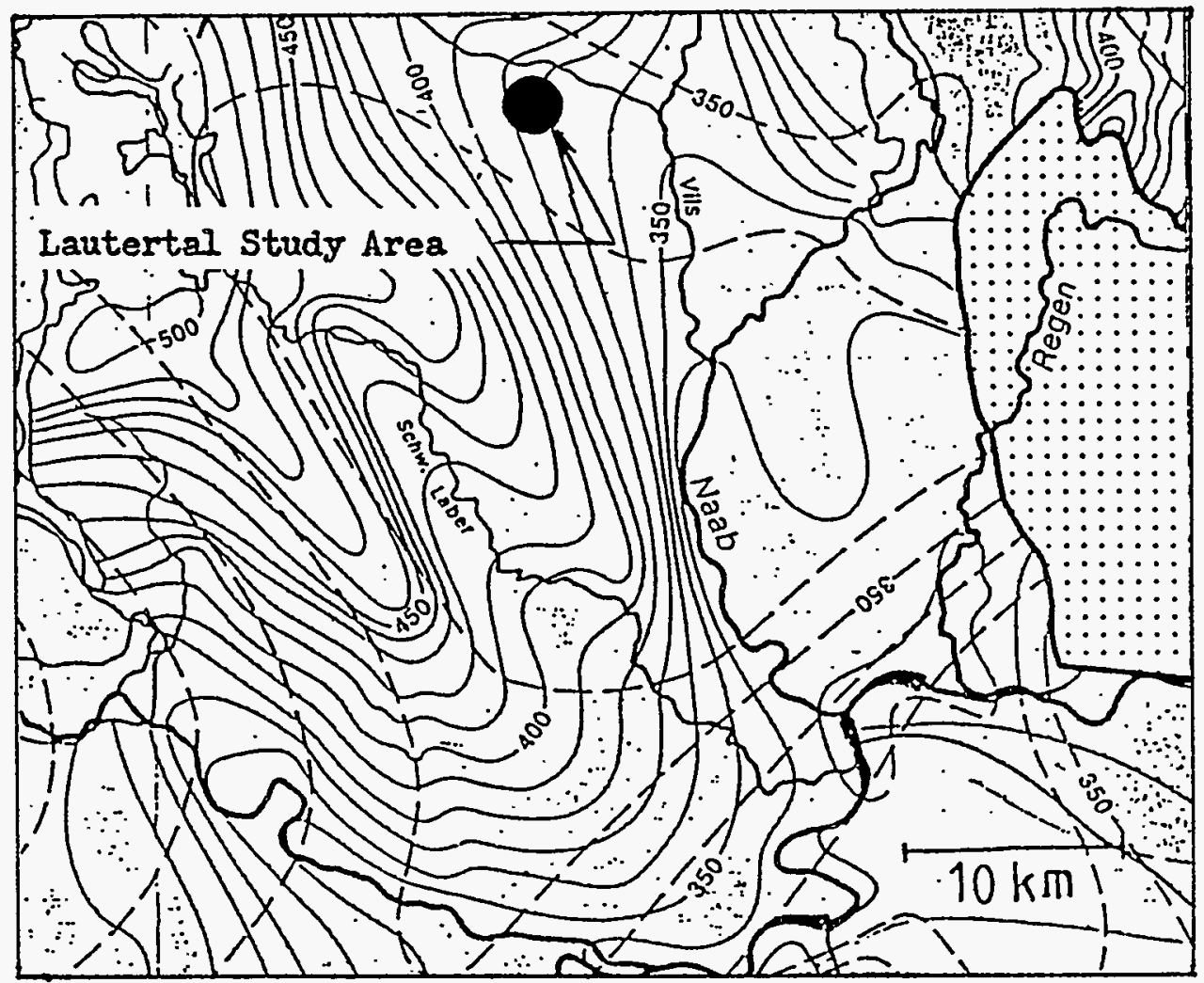

FIGURE 8 Water-Table Elevations in Bavaria (Adapted from Andres and Wirth, 1985) 


\section{Geophysical Exploration}

\subsection{Land Surveying}

In order to facilitate the collection, reduction, and interpretation of geophysical data, an orthogonal grid was established over the Lautertal by Wolf-Blumenthal Ingenieurbüro, Nürnberg (see Figure 2). The lines of this grid were oriented in north-south and east-west directions, and nodal spacing was $0.125 \mathrm{~km}$. The locations of the nodes were accurate to $1.0 \mathrm{~m}$ in the horizontal and $0.1 \mathrm{~m}$ in the vertical (see Table A.1 in Appendix A). A computer-generated surface topography map of the study area, based on nodal elevations, is shown in Figure 9. All but a few of the geophysical measurements made in this study were located at nodes or along lines of the orthogonal grid.

\subsection{Electromagnetic Surveying}

Electromagnetic surveying provided a rapid, qualitative examination of the electrical properties (conductivity) of the near-surface deposits in the Lautertal study area. Electromagnetic readings were made with a Geonics EM-34 instrument at 220 nodes of the orthogonal grid covering the Lautertal study area. At each node, three apparent conductivity values (in millimhos/meter) were obtained by holding the transmitting and the receiving coils on the earth's surface in the same vertical plane (horizontal dipoles) at spacings of 10,20 , and $40 \mathrm{~m}$ (see Table A.2). The apparent conductivity values represent weighted averages of the conductivities of the rocks between the transmitter and the receiver. The conductivities of the rocks near the earth's surface are weighted most heavily, and the depth of investigation is generally some fraction of the spacing between the transmitter and the receiver. This fraction is dependent on the conductivities of the rocks. Increasing the spacing between the transmitter and the receiver increases the depth of investigation (Telford et al. 1976).

In this study, the apparent conductivity values ranged from 0.1 to $29.0 \mathrm{mmho} / \mathrm{m}$. The largest values are associated with fine-grained unconsolidated deposits (loam and loess). The intermediate values are generally associated with coarse unconsolidated deposits (alluvium and colluvium) and perhaps fractured and/or dissolved carbonate bedrock. The smallest conductivity values are associated with competent carbonate bedrock.

Areal distributions of apparent conductivity in the Lautertal corresponding to transmitterreceiver spacings of 10,20 , and $40 \mathrm{~m}$ are shown in Figures 10,11, and 12, respectively. (Other visualizations of the electrical conductivity distributions are shown in Appendix B, Figure B.1.) At all three spacings, the largest apparent conductivity values appear to be collocated along distinct north-south and east-west linear trends. Further, as the transmitter-receiver spacing increases and the depth of investigation also increases, the width of these trends and the largest apparent conductivity values within these trends decrease. These observations indicate the presence of 


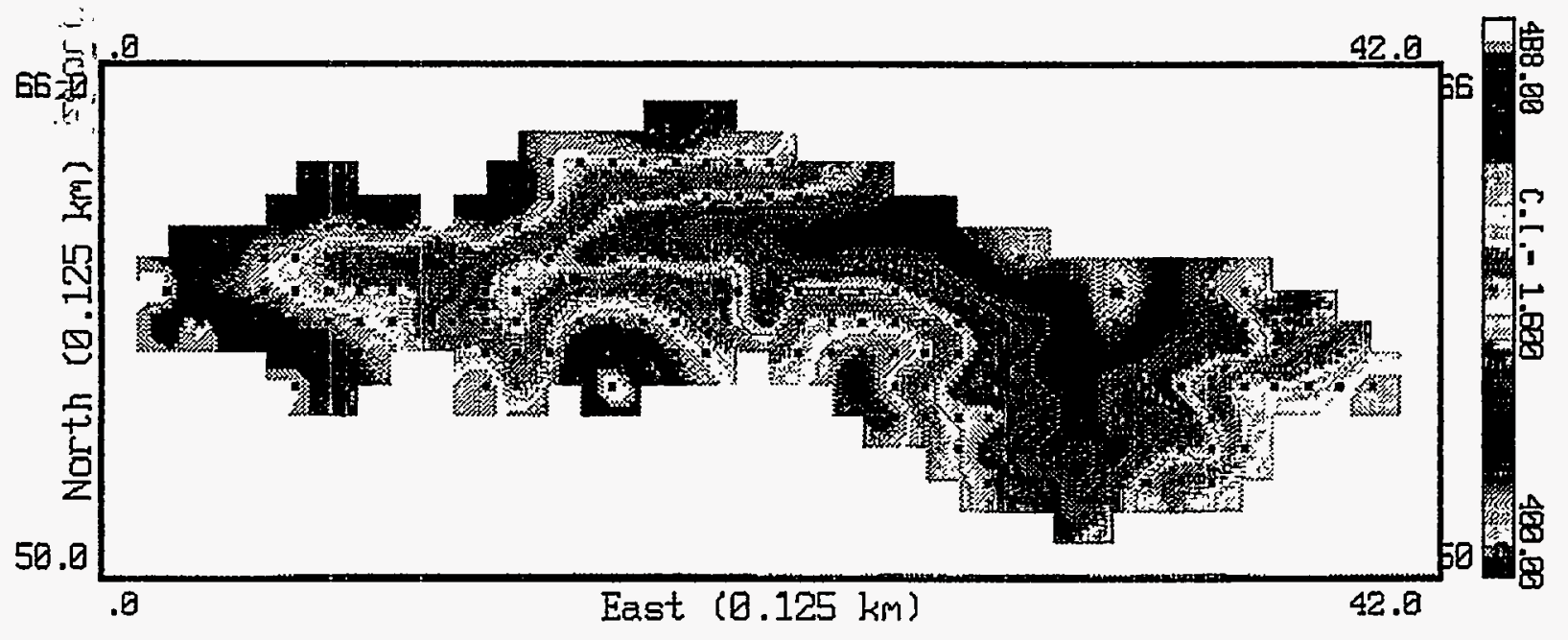

FIGURE 9 Surface Topography of the Lautertal Study Area

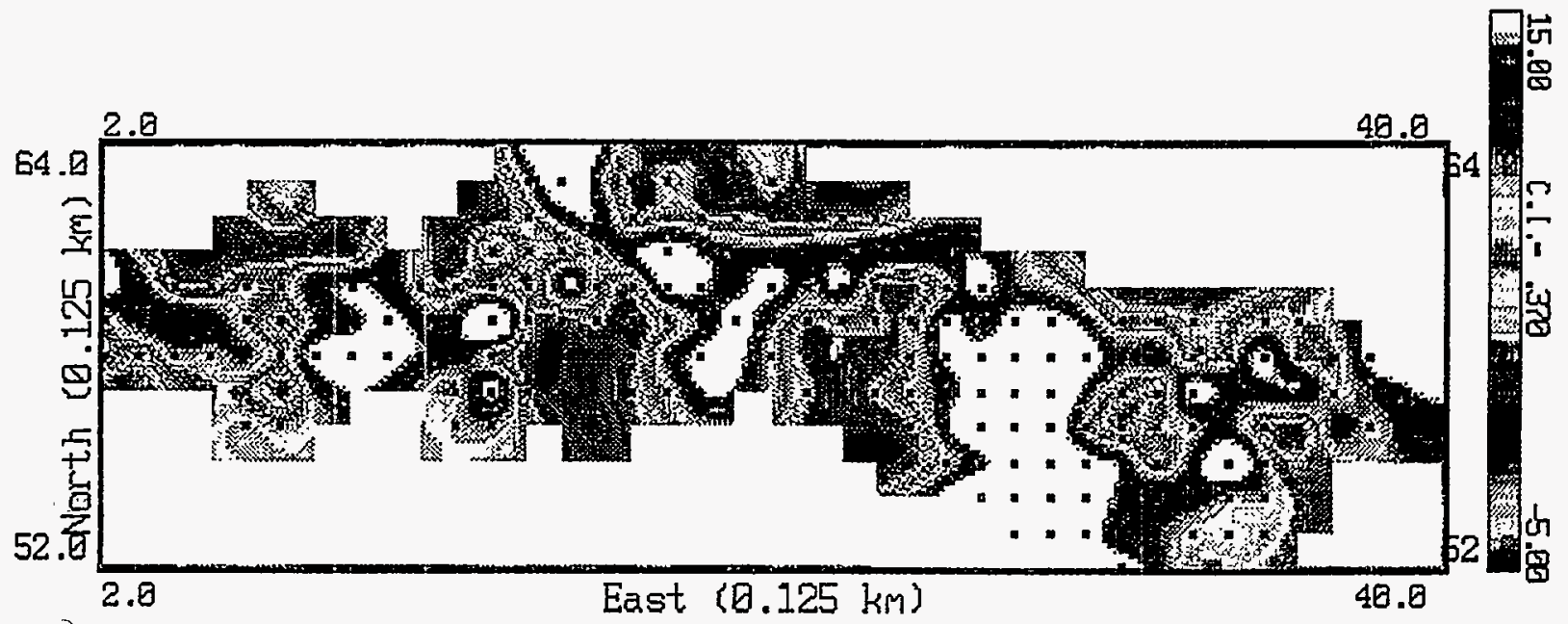

FIGURE 10 Areal Distribution of Apparent Conductivity as Determined by Electromagnetic Surveying with a 10-m Transmitter-Receiver Spacing 


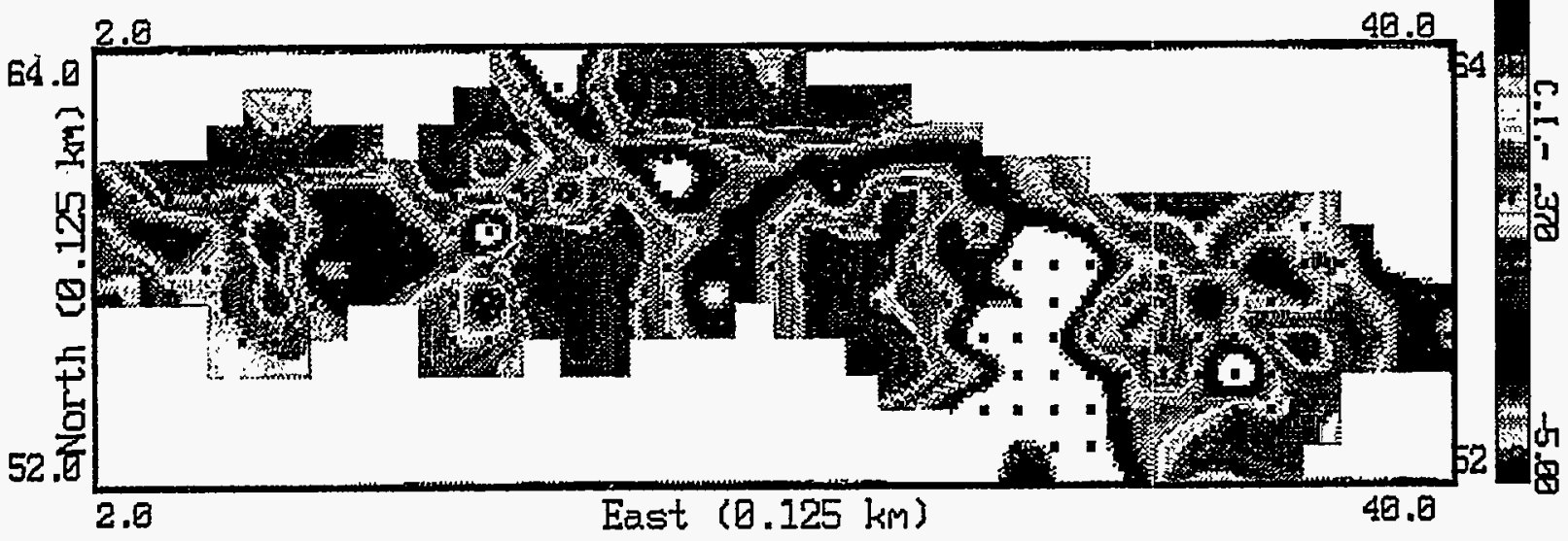

FIGURE 11 Areal Distribution of Apparent Conductivity as Determined by Electromagnetic Surveying with a 20-m Transmitter-Receiver Spacing

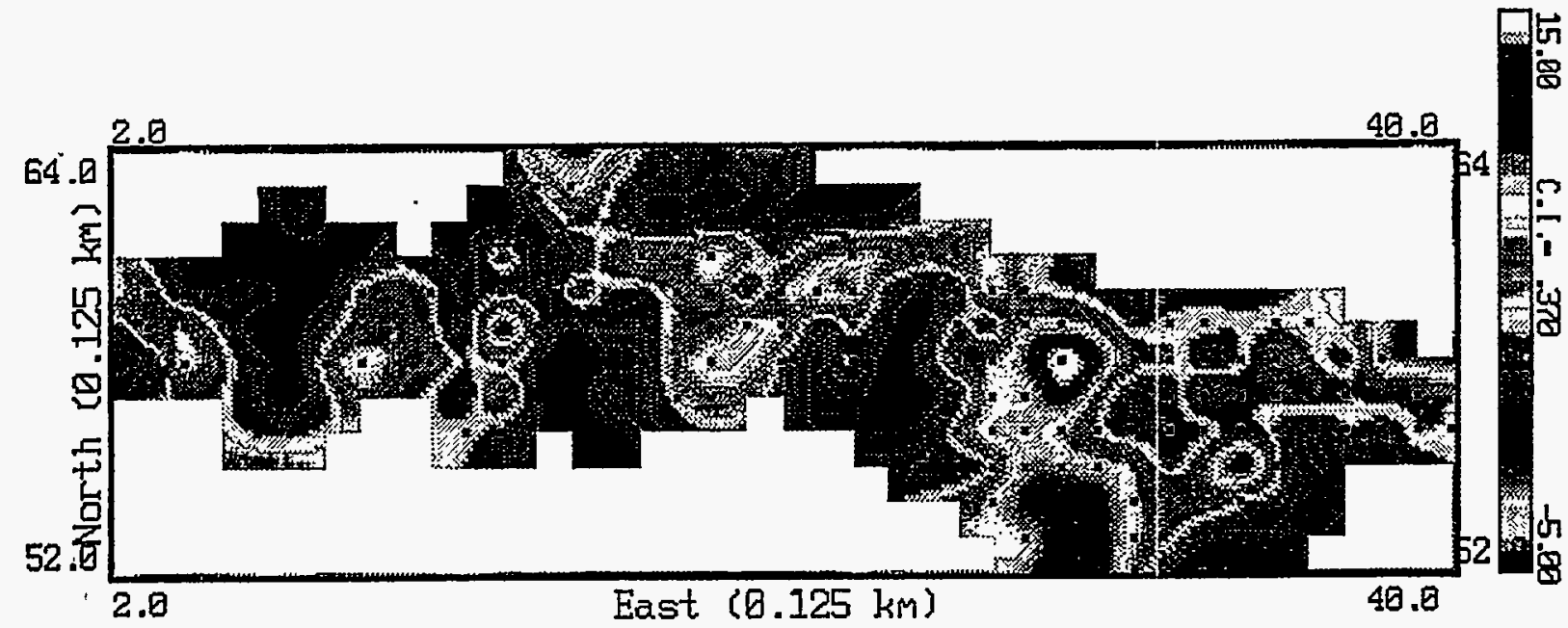

FIGURE 12 Areal Distribution of Apparent Conductivity as Determined by Electromagnetic Surveying with a 40-m Transmitter-Receiver Spacing 
channels and other depressions on the bedrock surface that have been filled with unconsolidated deposits - first, generally coarse alluvium and colluvium, then, fine-grained loam and loess. These latter deposits blanket most of the Lautertal, but they may reach their greatest thickness above channels and other depressions in the bedrock surface that have not been completely filled with alluvium and colluvium. The fact that the width and amplitudes of the high apparent conductivity trends are greatly reduced in Figure 12 indicates that the maximum depths of the channels and other depressions in the bedrock surface are approximately $40 \mathrm{~m}$.

According to the electromagnetic data, the main channel in the bedrock surface is relatively broad and transects the Lautertal in an approximate north-south direction near the west side of Wüstung Eggertsheim (north-south grid line 29). The loci of the lowest surface elevations in the Lautertal lie almost directly above this main channel in the bedrock surface (Figure 9). Smaller channels in the bedrock surface that roughly parallel the axis of the Lautertal, and that have tributaries of their own, join the main channel in the bedrock surface from the east and from the west.

\subsection{Vertical Electrical Soundings}

Vertical electrical soundings provided a "quantitative" examination of the electrical properties (resistivity, the reciprocal of conductivity) of the near-surface deposits in the Lautertal study area. The term quantitative, as used here, indicates that the data acquired by using this method were able to be inverted to layering parameters (resistivities and thicknesses). While it may appear that there was a redundancy in employing this geophysical method in addition to electromagnetic surveying, because both methods essentially measure the same geophysical parameter, the fact is that these two methods complement each other. The vertical electrical soundings serve to constrain the qualitative, but more voluminous, electromagnetic data.

Vertical electrical soundings were made with an ABEM Terrameter System, Model SAS $300 \mathrm{C}$, at 147 nodes of the orthogonal grid covering the Lautertal. At each station, a-spacings of a Wenner electrode configuration were expanded in appropriate increments to provide a smooth, yet detailed, curve of apparent resistivity (in ohm-meters) versus a-spacing (in meters). Maximum a-spacings were usually $120 \mathrm{~m}$.

The apparent resistivity values obtained in vertical electrical soundings represent weighted averages of the resistivities of the rocks between the potential surfaces that intersect the earth's surface at the potential (inner) electrodes of the Wenner electrode configuration. The resistivities of the rocks near the earth's surface are weighted most heavily, and the depth of investigation is generally some fraction of the distance between the potential electrodes (which is also the a-spacing). Increasing the a-spacing increases the depth of investigation.

Apparent resistivity versus a-spacing curves were inverted to layering parameters (resistivities and thicknesses) by using the commercially available software package, Resix Plus (Table A.3). Resix Plus assumes that the observed apparent resistivity versus a-spacing curves 
are the result of a series of horizontal layers below the center point of the Wenner electrode configuration.

Inversion of the vertical electrical sounding data gathered in the Lautertal provided information about three near-surface layers of rock. In descending order, these layers correspond to the fine-grained loam and loess, the generally coarse alluvial and colluvial deposits, and the carbonate bedrock. A three-dimensional view of the shallow geological framework of the Lautertal as determined by vertical electrical soundings, is shown in Figure B.2. As indicated in Section 2, in the Lautertal, away from the channels and depressions in the bedrock surface, the middle layer of alluvial and colluvial deposits is absent. The carbonate bedrock surface may be highly fractured and/or dissolved or quite competent. Coarse alluvial and colluvial deposits can have resistivity values quite similar to those of highly fractured and dissolved carbonate rock. Thus, when these two rock types are juxtaposed, the location of their interface is often difficult to determine on the basis of vertical electrical sounding data. Occasionally, the inversion of the vertical electrical sounding data provided layering solutions consisting of more than three layers. Although such layering solutions are geologically feasible, such solutions may result from errors introduced during the acquisition of the data. For example, abrupt changes in elevations of the earth's surface encountered during the expansion of the Wenner electrode configuration may have caused "noise" in the acquired data. Such conditions were noted during the data acquisition, and inversions of data gathered under such conditions were viewed with appropriate caution.

Resistivity values of the normally well-drained, near-surface deposits in the Lautertal (the water table is normally below the bedrock surface) range from just a few ohm-meters to tens of thousands of ohm-meters (Table A.3). The lowest resistivity values are associated with the finegrained loam and loess that have retained meteoric water in their pore spaces. The highest resistivity values are associated with competent bedrock. A histogram showing the frequency of resistivity values of the near-surface layers (Figure 13) provided a basis for assigning a range of resistivity values to each of the three near-surface layers commonly observed in the Lautertal. The layer consisting of loam and loess has been assigned a range of resistivity values from 0 to $250 \Omega-\mathrm{m}$; the layer of alluvial and colluvial deposits has been assigned a range of resistivity values from 250 to $800 \Omega-\mathrm{m}$; and bedrock was assigned all resistivity values greater than $800 \Omega-\mathrm{m}$. Choosing the resistivity values separating the three layers was difficult, especially the resistivity value separating the alluvial and colluvial deposits from bedrock.

Locations where loam and loess cover alluvial and colluvial deposits are shown in Figure 14. The resistivity values of the alluvial and colluvial deposits are indicated. This figure corroborates and refines the findings of the electromagnetic data; that is, the alluvium and colluvium appear to be confined to generally north-south- and east-west-trending channels and other depressions in the bedrock surface. The resistivity values of the alluvium and colluvium show no apparent areal trends. This finding is not surprising given the manner in which these sediments were deposited and the possibility that some of the deposits thought to be alluvium and colluvium are, at least in part, fractured and/or dissolved carbonate bedrock. A three-dimensional view of the surface topography and the base of loam and loess is shown in Figure B.3. 


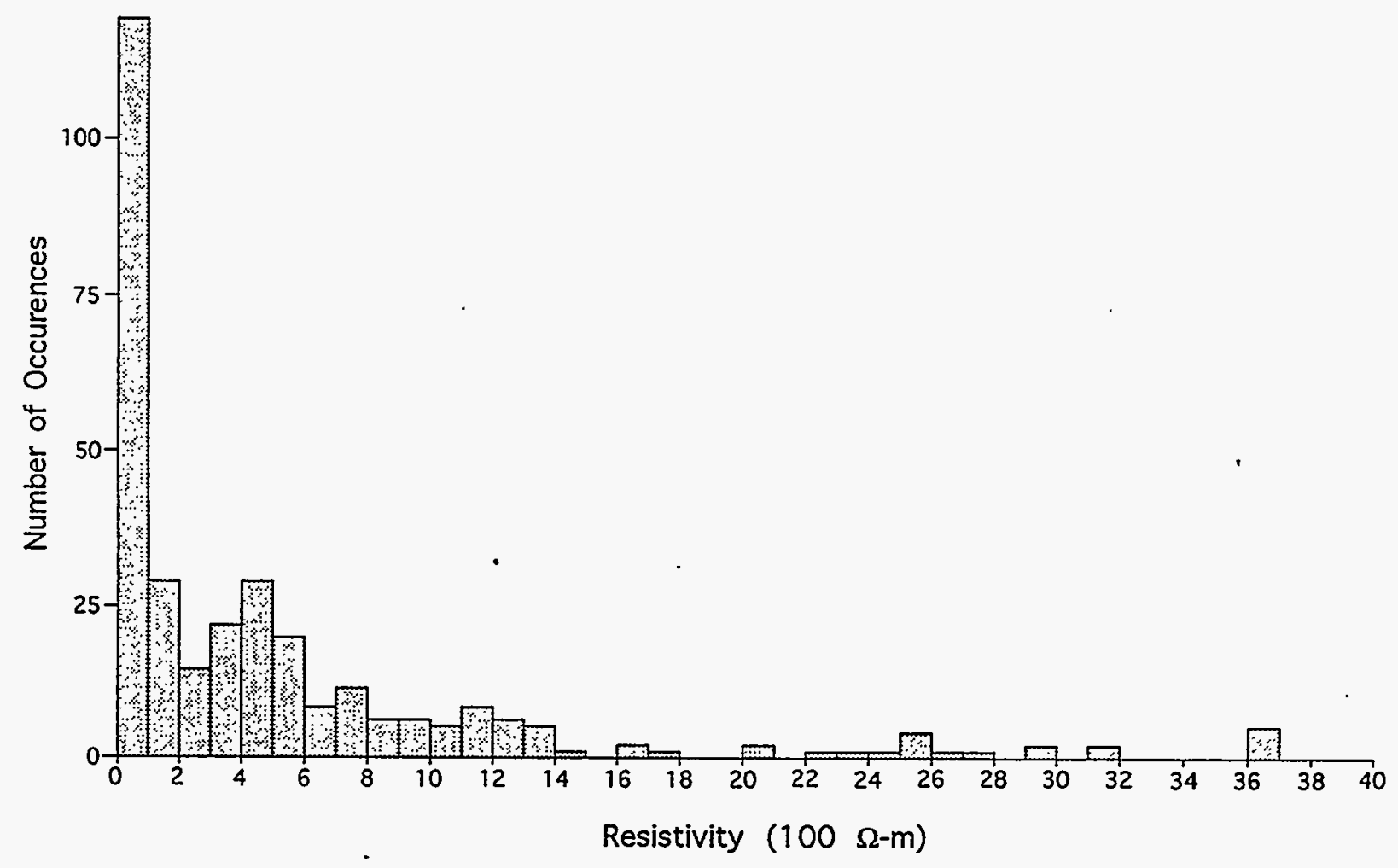

FIGURE 13 Frequency Distribution of the Resistivity of the Near-Surface Layers in the Lautertal Study Area

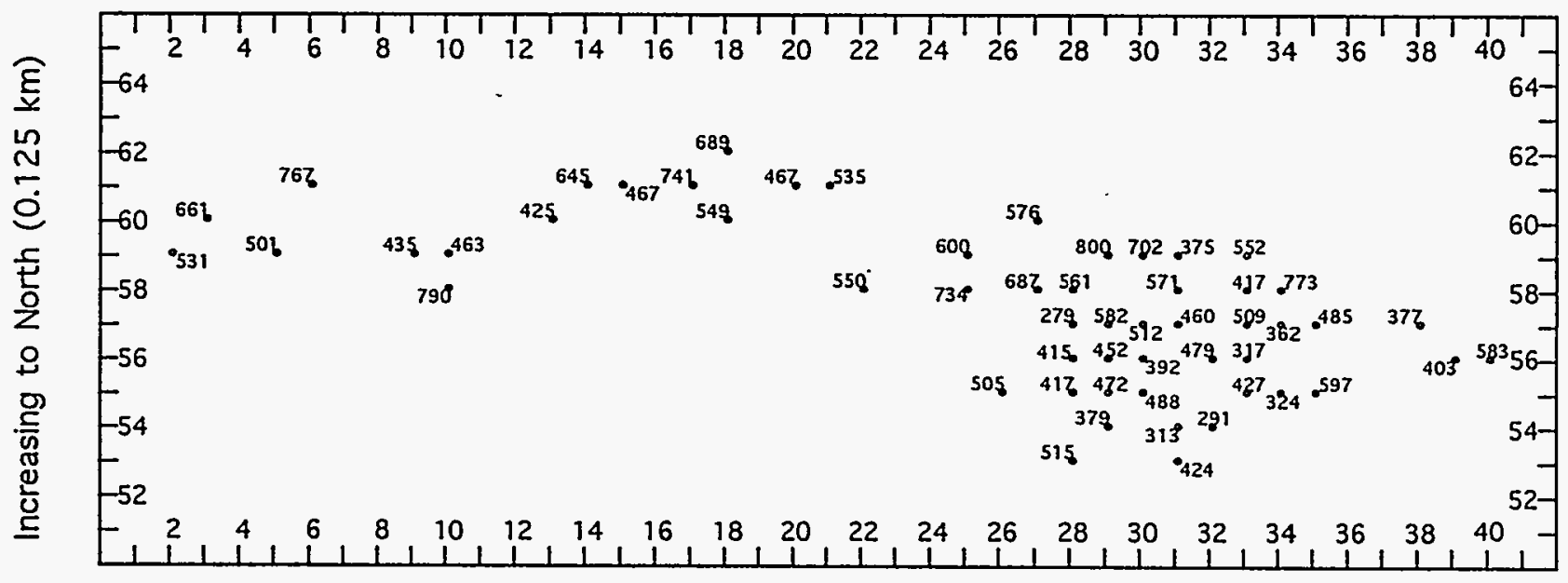

Increasing to East $(0.125 \mathrm{~km})$

FIGURE 14 Resistivity Distribution Showing Locations Where Loam and Loess Cover Alluvium and Colluvium in the Lautertal Study Area (resistivity values of the alluvial and colluvial deposits are shown in units of ohm-meters) 
Locations where the loam and loess lie directly on the bedrock surface are shown in Figure 15. The resistivity values of the bedrock surface are indicated. No areal trends in the resistivity values of the bedrock surface are apparent. (Again, see Figure B.3 for a threedimensional view of the surface topography and the loam and loess.) If the resistivity values of the bedrock could have been determined at locations in the Lautertal where alluvial and colluvial deposits were present, it might have been possible to discern areal trends related to fracturing and dissolution. As stated previously, coarse alluvial and colluvial deposits can have resistivity values quite similar to those of highly fractured and dissolved carbonate rocks, and, as a result, it is often difficult to separate these two lithotypes on the basis of vertical electrical sounding data.

The layering parameters determined by the inversion of the vertical electrical sounding data have also been used in conjunction with the results of the seismic refraction profiling part of this study to construct maps showing the thickness of the loam and loess, the thickness of the alluvial and colluvial deposits, and the topography of the bedrock surface. The vertical electrical sounding data were considered more reliable in the determination of the thickness of the loam and loess, while the seismic refraction data were considered more reliable in the determination of the thickness of the alluvial and colluvial deposits. Thus, a combination of the results of the vertical electrical soundings and the seismic refraction profiling was used to construct the map showing the topography of the bedrock surface. The loam and loess thickness map is shown in Figure 16. The presentation and discussion of maps showing the thickness of the alluvial and colluvial deposits and the topography of the bedrock surface is deferred to Section 4.4. The thickness of the loam and loess that blanket much of the Lautertal ranges from 0 to approximately $20 \mathrm{~m}$, with the mean value near the middle of that range. The thickness of these fine-grained deposits tends to be greatest above channels and other depressions on the bedrock surface that have not been completely filled with alluvial and colluvial deposits.

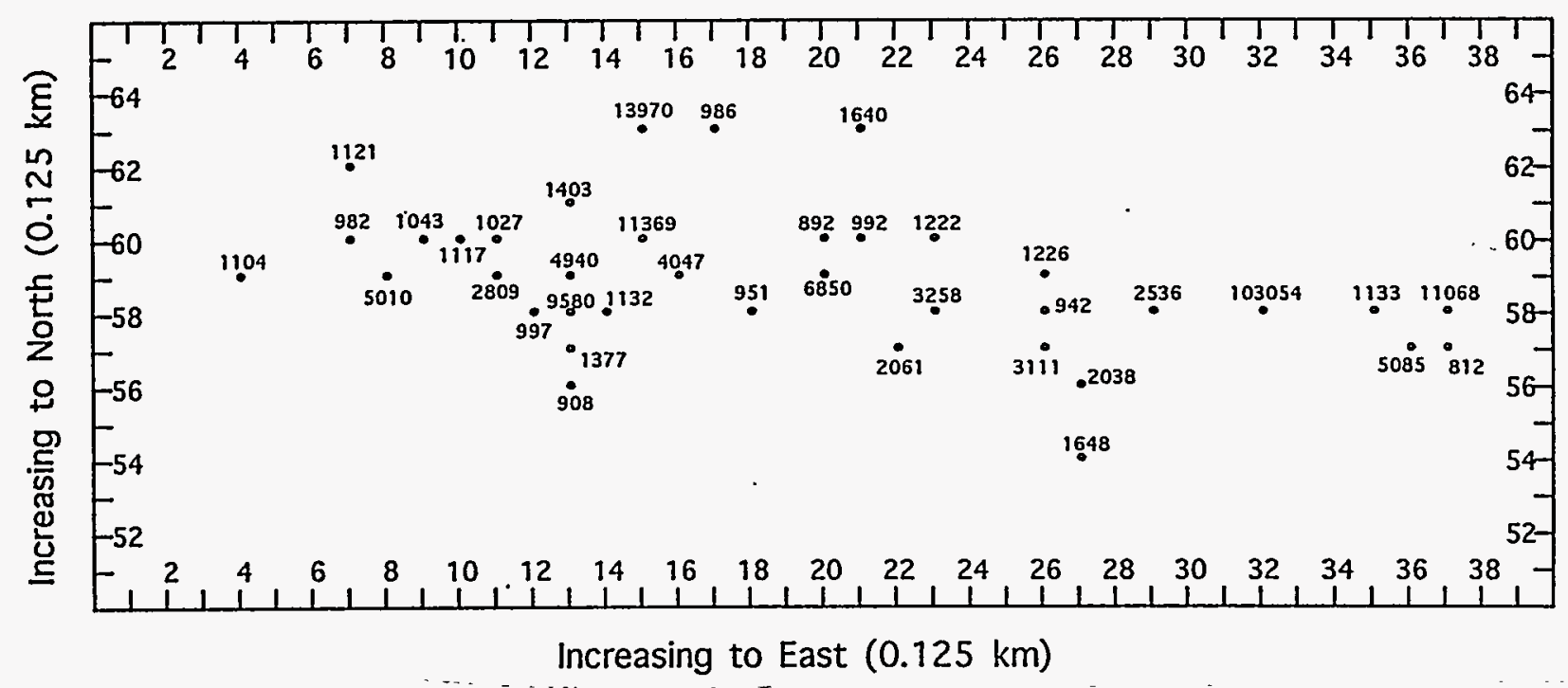

FIGURE 15 Resistivity Distribution Showing Locations Where Loam and Loess Lie Directly on Bedrock Surface in the Lautertal Study Area (resistivity values of the bedrock are shown in units of ohm-meters) 


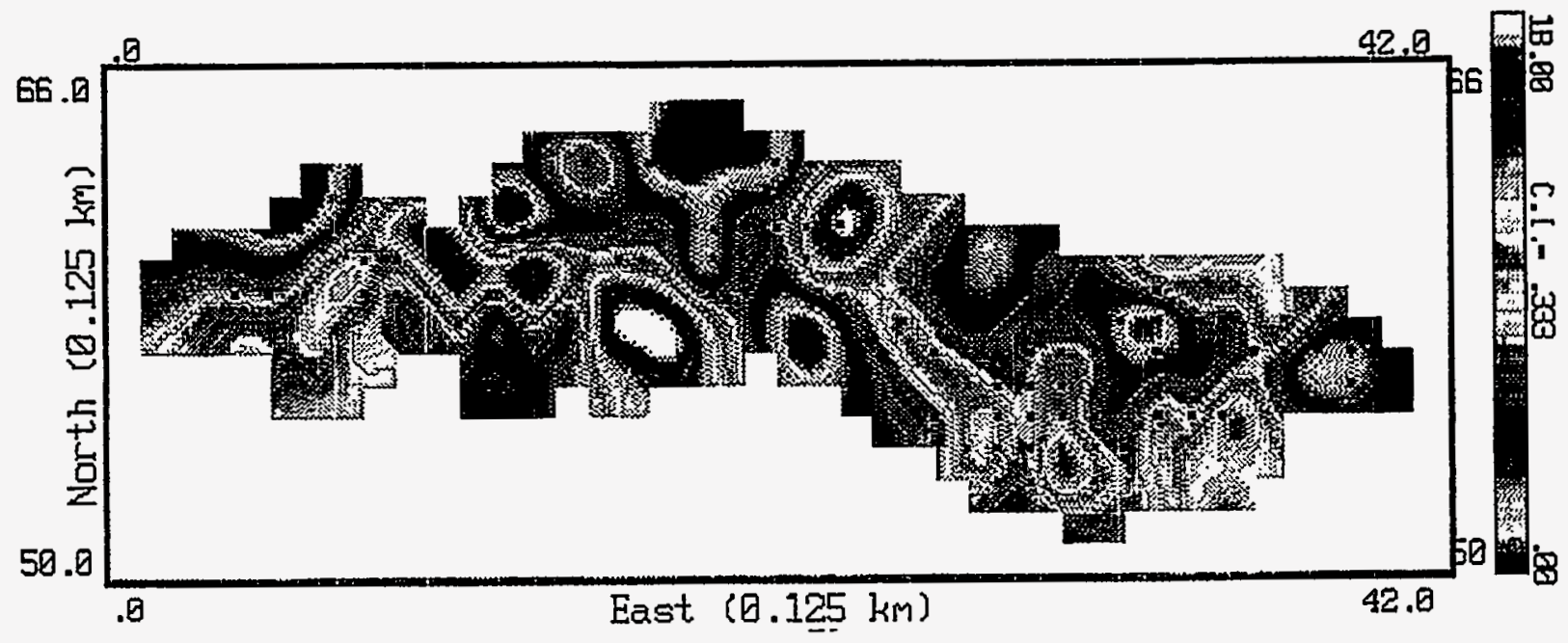

FIGURE 16 Thickness of the Loam and Loess in the Lautertal Study Area

\subsection{Seismic Refraction Profiling}

Seismic refraction profiling provided another examination of the nature of the near-surface deposits in the Lautertal. This method, perhaps the most definitive of the three employed in this study, involved the use of an energy source to generate seismic waves. Measurements of the travel times of the seismic waves were used to determine the velocity (in meters/second) distribution and the discontinuities of the elastic properties in the near-surface deposits.

Reversed seismic refraction profiles were run at 51 locations throughout the Lautertal. A 12-channel Bison Series 5000 system, along with Geosense $14.5-\mathrm{Hz}$ vertical component geophones, were employed in this phase of the geophysical study. The length of each profile was usually $120 \mathrm{~m}$ (10-m geophone spacing). This length was adequate to obtain the depth to the bedrock surface and the velocities of the unconsolidated deposits and the bedrock surface. At some locations, where the unconsolidated deposits resting on the bedrock surface were known to be thin, the length of the profiles was shortened to $60 \mathrm{~m}$ (5-m geophone spacing). The source of energy was $0.25 \mathrm{~kg}$ of Seismogelit detonated by an instantaneous electrical blasting cap in a handaugured hole approximately $1.0 \mathrm{~m}$ deep.

The locations of the seismic refraction profiles were chosen to optimize the amount of information about the shallow geological framework of the Lautertal in the available time. The information obtained from the seismic refraction profiling should complement the information obtained from the electromagnetic surveying and the vertical electrical soundings. In all but a few cases, the seismic refraction profiles were located on relatively flat terrain, along lines and betweẹn nodes of the orthogonal grid covering the Lautertal, to ensure that the geophones were at the same approximate elevation and that the shot-point elevations were known within a meter. 
Reduction of the seismic refraction data, a series of time-distance plots, followed a scheme described by Heiland (1968). This scheme assumes that the earth's surface and the interfaces separating layers of rock are planar, at least between the shot points. It also assumes that the velocity of each layer is homogeneous and isotropic between the shot points. If the assumptions of Heiland's scheme are met, points on the time-distance plots will fall on a series of straight lines. Normally, undulations on the earth's surface and/or interfaces and variations in the velocities within the layers cause points on the time-distance plots to deviate from straight lines. In this study, this difficulty was accounted for by fitting least-squares line segments to the appropriate points on the time-distance plots. Results obtained from Heiland's scheme include velocities of the layers, depths to the interfaces below the shot points, and locations of the dips of the interfaces between the shot points (Table A.4).

Reduction of the seismic refraction data was, as previously indicated by the vertical electrical sounding data, a problem involving three layers: (1) loam and.loess, (2) alluvial and colluvial deposits, and (3) carbonate bedrock. (Away from the channels and other depressions in the bedrock surface, where the alluvium and colluvium were absent, reduction of the data was a simpler two-layer problem.) A three-dimensional view of the shallow geological framework of the Lautertal, as determined by seismic refraction profiling, is shown in Figure B.4. The three layers had velocities that increased monotonically with depth. The layer of fine-grained loam and loess had a mean velocity of $525 \mathrm{~m} / \mathrm{s}$; the layer of alluvium and colluvium had a mean velocity of $1,553 \mathrm{~m} / \mathrm{s}$; and the mean velocity of the bedrock surface was $3,721 \mathrm{~m} / \mathrm{s}$. The velocity of the bedrock surface had a wide range - from 2,320 to $7,646 \mathrm{~m} / \mathrm{s}$. This velocity is characteristic of karstic terrain and highly variable water content. The mean velocities of the two layers of unconsolidated deposits are low, even for the types of deposits comprising these layers. The low values indicate that these deposits were well-drained at the time the seismic refraction profiling was done.

A histogram showing the frequency of the velocities of the near-surface deposits in the Lautertal (Figure 17) clearly indicates the ranges of velocities associated with the three layers. Although the range of velocities associated with the carbonate bedrock is large, it does not appear to overlap the range of velocities associated with the alluvium and colluvium. Thus, velocity is a better parameter than resistivity for differentiating between the alluvial and colluvial deposits and the fractured and/or dissolved bedrock.

Locations where the alluvial and colluvial deposits were encountered during the seismic refraction profiling are shown in Figure 18. The velocity values of these deposits are also shown in this figure. Inspection of the areal distribution of the velocities of the alluvium and colluvium deposits does not indicate any significant trends.

Locations where the seismic refraction profiling was able to determine the depth to bedrock are shown in Figure 19. The velocities of the rocks forming the bedrock surface are also shown in this figure. Visual examination of the areal distribution of the bedrock velocities does not indicate any significant trends. However, these velocities were subjected to statistical analysis in an attempt to determine whether the velocities in the bedrock channels were significantly different 


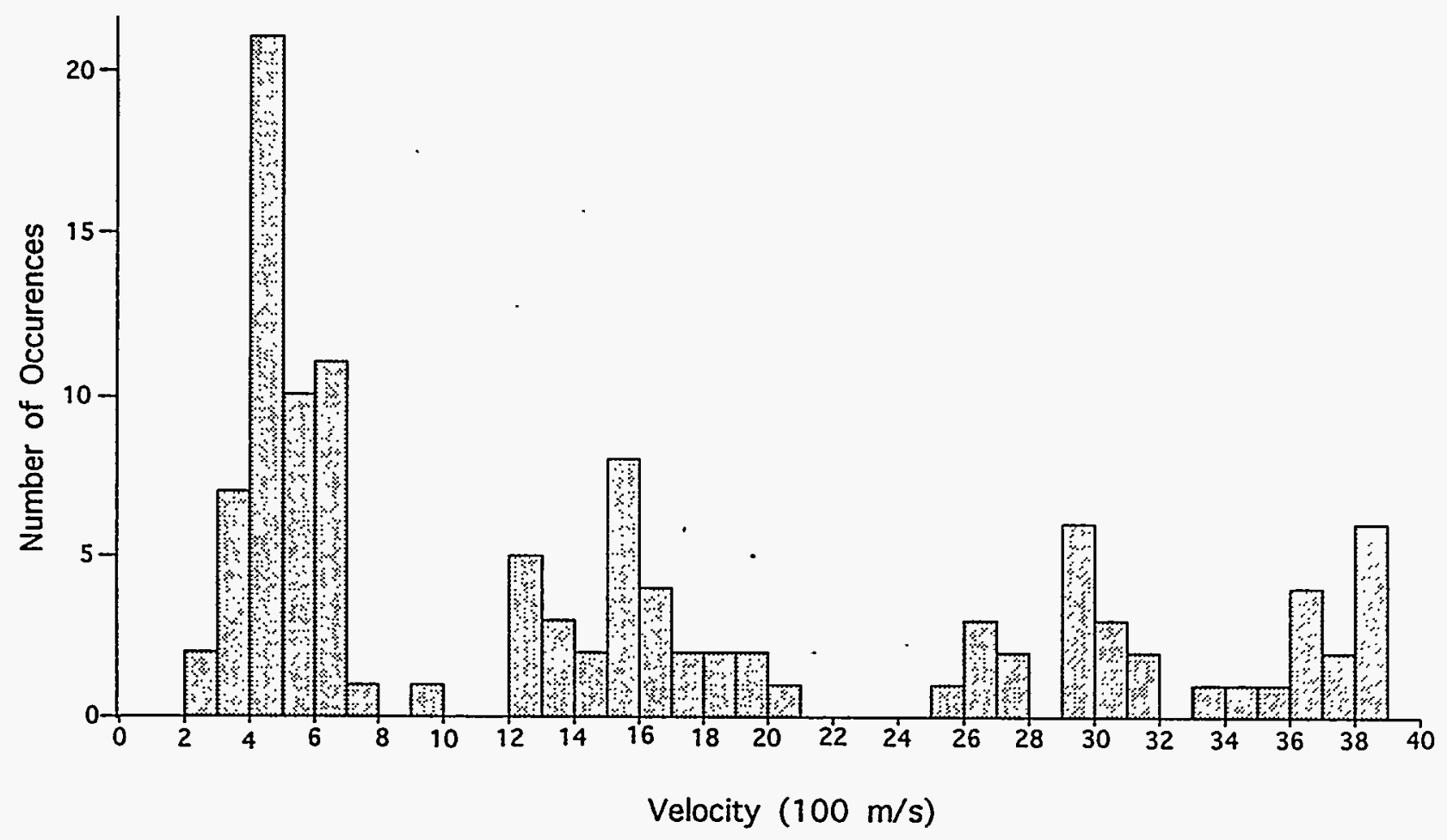

FIGURE 17 Frequency Distribution of the Velocities of the Near-Surface Deposits in the Lautertal Study Area

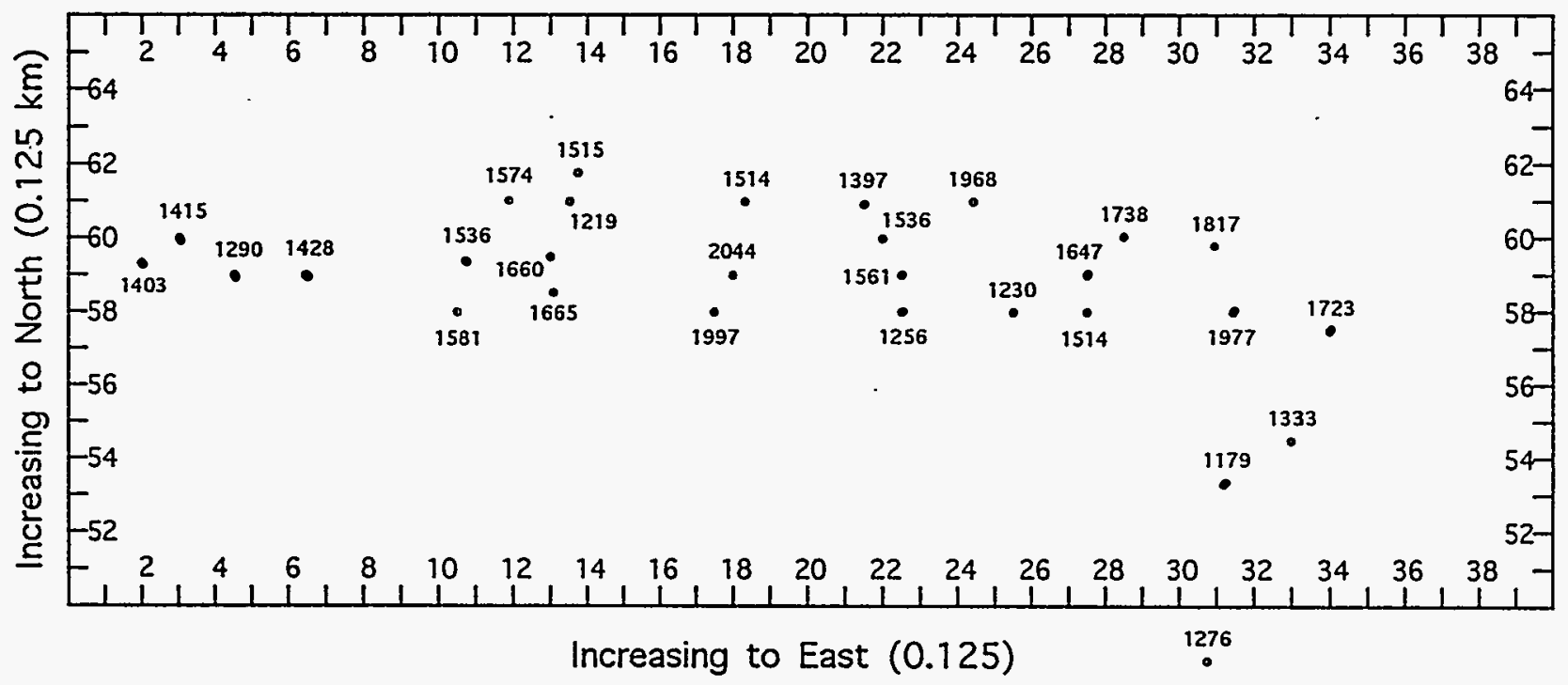

FIGURE 18 Areal Distribution of the Velocities of the Alluvium and Colluvium in the Lautertal Study Area (showing velocity values of the alluvial and colluvial deposits in units of meters per second) 


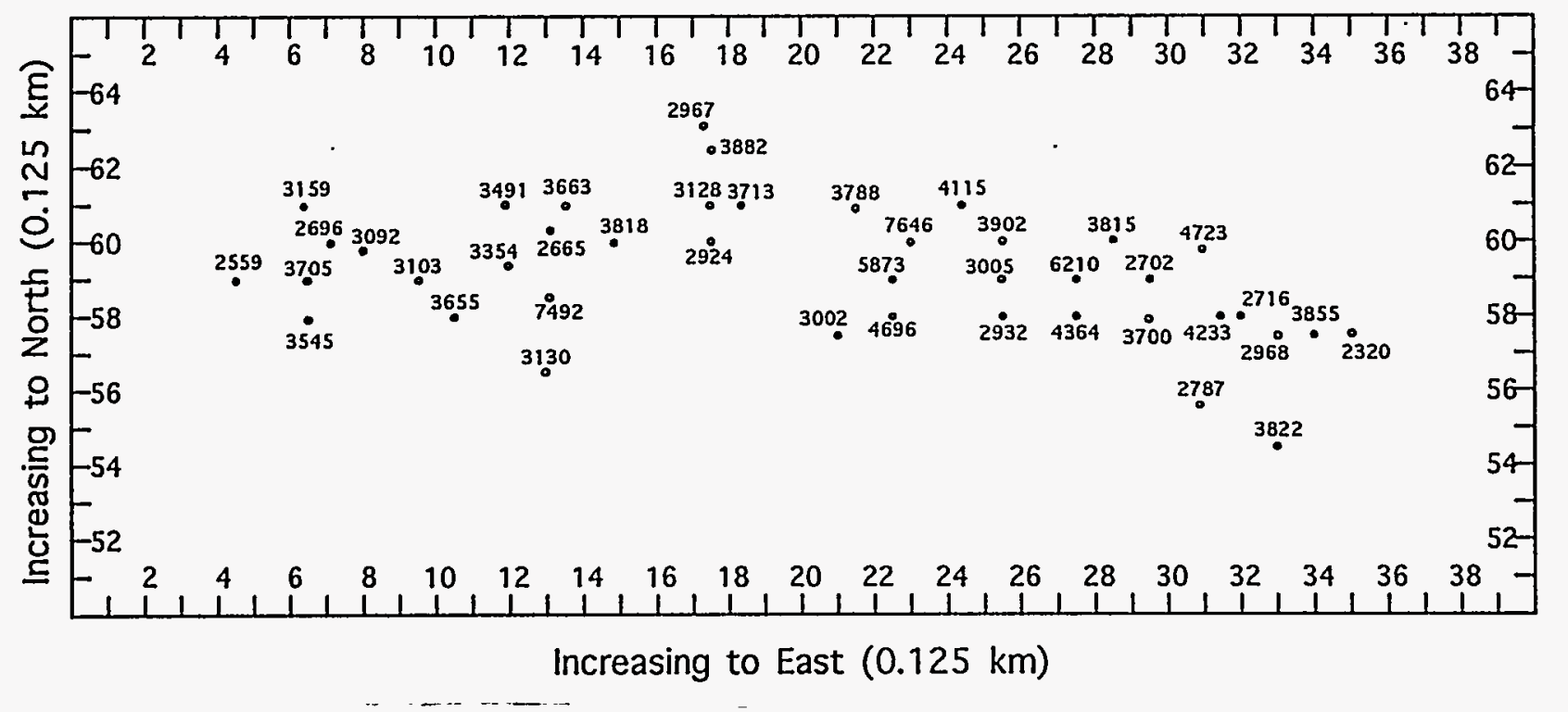

FIGURE 19 Areal Distribution of the Velocities of the Bedrock Surface in the Lautertal Study Area (showing velocities of the bedrock surface in units of meters per second)

from the velocities away from the bedrock channels. The number of bedrock velocity values was limited; therefore, a statistical test was performed in which the hypothesis was stated in terms of population means, and the t-distribution was employed (Lindgren 1960). The sample mean of the bedrock surface velocities in the bedrock channels was $4,247 \mathrm{~m} / \mathrm{s}$, whereas the sample mean of the bedrock surface velocities away from the bedrock channels was $3,313 \mathrm{~m} / \mathrm{s}$. Results of the statistical test indicate that this difference is significant at the $95 \%$ confidence level. The greater mean velocity of the bedrock in the channels is due to the fact that bedrock elevations are lower and the bedrock is saturated. Away from the bedrock channels, the bedrock surface is above the water table. Thus, water content likely plays a greater role than porosity in the determination of the bedrock velocity.

As mentioned previously, results of the seismic refraction profiling were used in conjunction with the results of the vertical electrical soundings to construct maps showing the thickness of the loam and loess, the thickness of the alluvium and colluvium, and the topography of the bedrock surface in the Lautertal. The map showing the thickness of the loam and loess in the Lautertal (Figure 16) was discussed in Section 4.3. The map indicating the thickness of the alluvial and colluvial deposits in the Lautertal is shown in Figure 20. As expected, these deposits were thickest over channels and depressions in the bedrock surface, with the maximum thickness (where measured) in excess of $30 \mathrm{~m}$. The topography of the bedrock surface in the Lautertal is shown in Figure 21. Elevations on the bedrock surface ranged from 385 to $472 \mathrm{~m}$ above mean sea level. The lowest elevation on the bedrock surface, as measured by the combination of geophysical methods, is located near the lowest surface elevations in the Lautertal, where surface runoff exits the Lautertal before joining the Lauterach. This low point on the bedrock surface is in the thalweg of the broad, north-south-trending bedrock channel that, as the electromagnetic data suggest, transects the Lautertal on the western side of Wüstung Eggertsheim. A cross section of this north-south-trending bedrock channel is shown in Figure 22. The bedrock surface is quite 


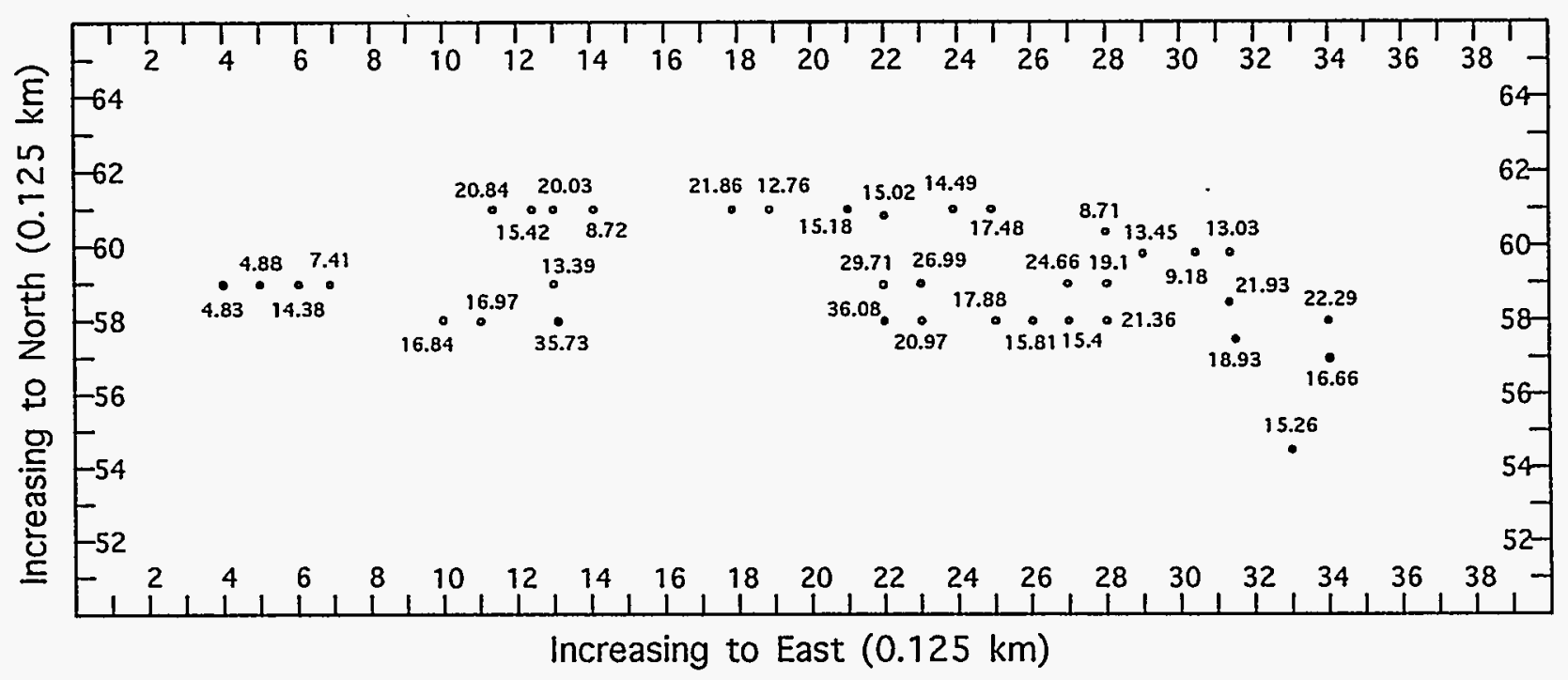

FIGURE 20 Thickness of the Alluvium and Colluvium in the Lautertal Study Area (showing thickness of the alluvial and colluvial deposits in units of meters)

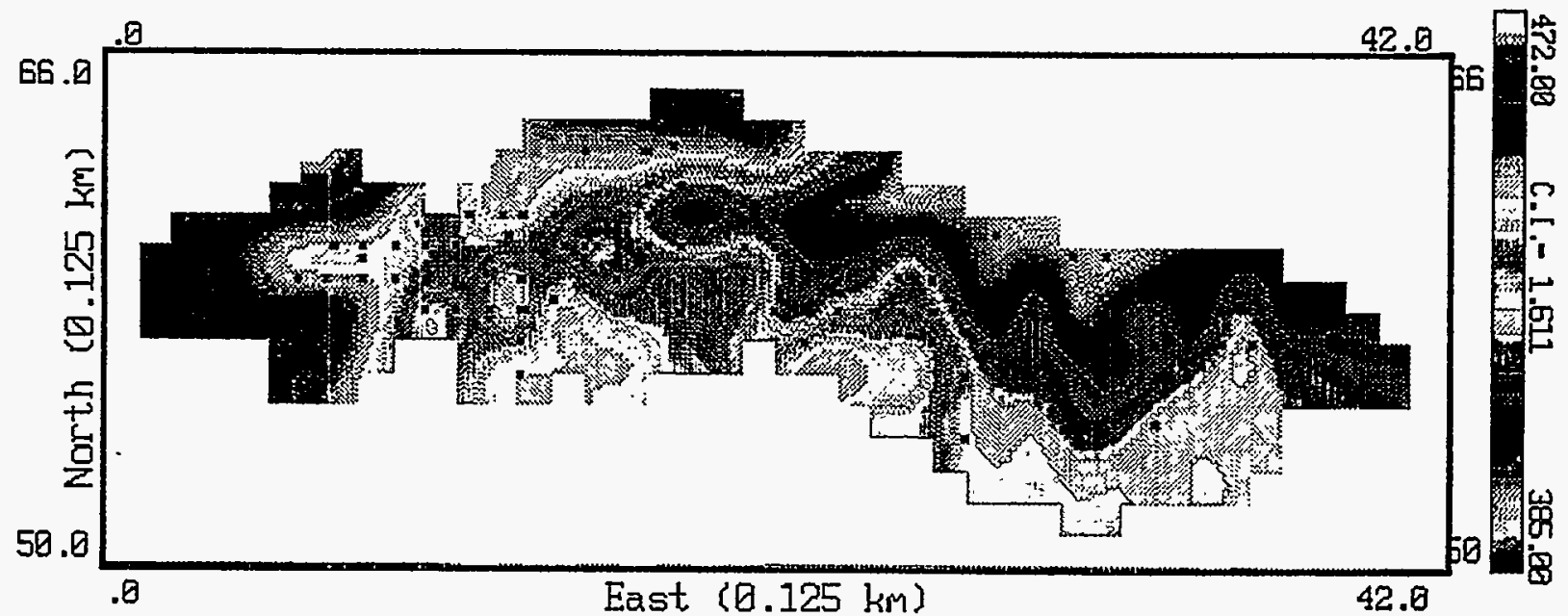

FIGURE 21 Bedrock Topography in the Lautertal Study Area 


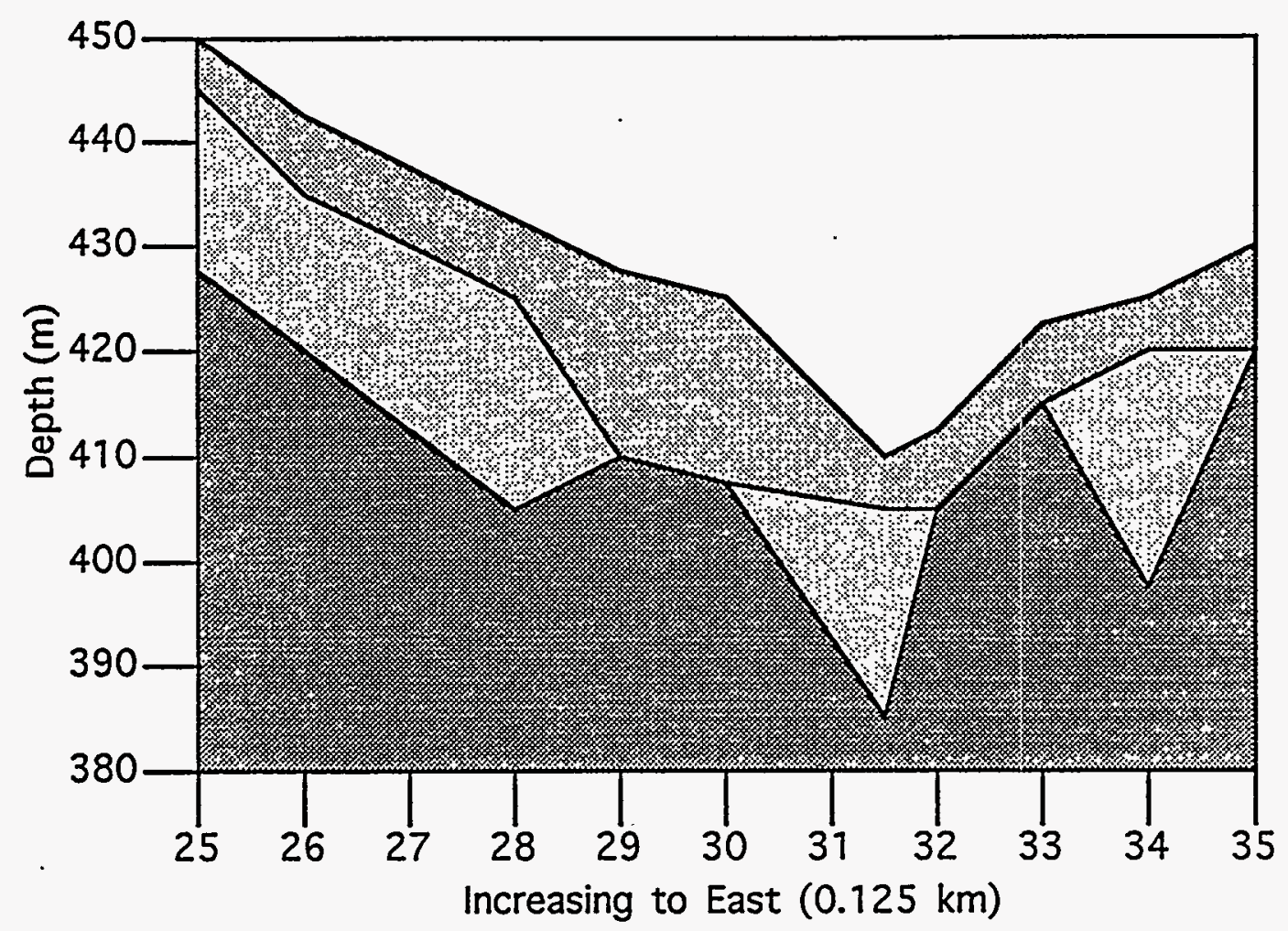

FIGURE 22 Cross Section of the Main North-South-Trending Bedrock Channel in the Lautertal along Line 58 North

irregular, with coarse alluvial and colluvial deposits filling low points on the bedrock surface, whereas the fine-grained loam and loess blanket the entire valley. Note that the loam and loess had thickened over the thalweg before they were eroded by surface drainage. The alluvial and colluvial deposits that continue to the west are associated with an east-west-trending tributary channel. A cross section of that same tributary channel, further to the west in the Lautertal, is shown in Figure 23. Here again the alluvial and colluvial deposits fill the lowest points in the tributary channel before being covered with loam and loess. The highest elevations on the bedrock surface are located in the western and northwestern parts of the Lautertal. At these locations, there are no deep channels or depressions in the bedrock surface and no alluvial and colluvial deposits.

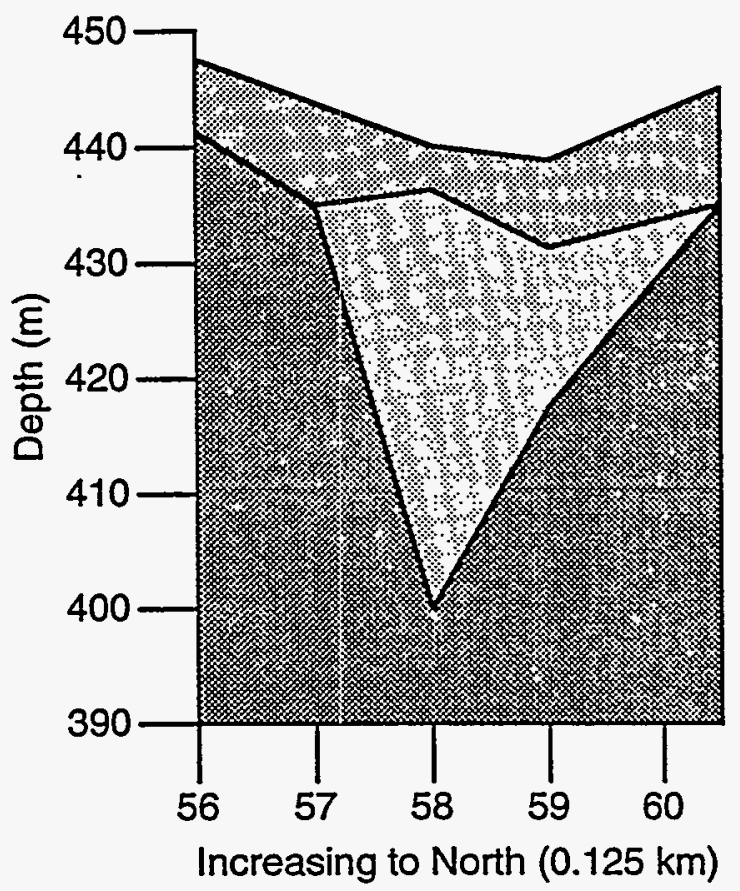

FIGURE 23 Cross Section of the EastWest-Trending Bedrock Channel in the Lautertal (tributary to the main bedrock channel) along Line 13 East 


\section{Discussion}

Geophysical exploration was successfully used to determine the shallow geological framework of the Lautertal at the Combat Maneuver Training Center in Hohenfels, Germany. The near-surface deposits in this dry valley, which are typical of the karstic environment of the southern Frankische Alb, consist of three basic layers: (1) a surficial layer of fine-grained loam and loess, (2) a layer of coarse alluvial and colluvial deposits, and (3) a highly fractured and dissolved carbonate bedrock. The layer of fine-grained loam and loess covers most of the Lautertal. The alluvial and colluvial deposits appear to be confined to channels and other depressions in the karstic bedrock surface. The channels and other depressions in the bedrock surface form a trellis-like pattern that is consistent with the preferred directions of fractures and joints in the bedrock. At the time when the geophysical investigations were being conducted in the Lautertal, the two layers of unconsolidated deposits appeared to be well-drained.

All of the geophysical methods employed in this study - electromagnetic surveying, vertical electrical soundings, and seismic refraction profiling - made significant contributions to the understanding of the shallow geological framework of the Lautertal. Even though the individual methods had shortcomings, the three methods complemented each other well. They should be included in similar future exploration programs.

The electromagnetic surveying provided a qualitative view of the electrical properties of the near-surface deposits. In this method, electrical conductivity is the parameter that is related to lithology. From the findings of this surveying, the locations and shapes of channels and other depressions in the low-conductivity carbonate bedrock surface were determined, and the higherconductivity unconsolidated deposits resting on the bedrock surface were separated into two layers: (1) a layer of less-conductive, coarse deposits (alluvium and colluvium) confined to bedrock channels and depressions and (2) a layer of more-conductive fine-grained deposits (loam and loess).

The vertical electrical soundings provided a quantitative view of the electrical properties of the near-surface deposits. Layering parameters (resistivities and thicknesses), obtained by inverting data gathered in the field, confirmed and refined the results of the electromagnetic surveying. There were, however, disappointments associated with the vertical electrical soundings. The lack of resistivity contrast between the well-drained, coarse alluvial and colluvial deposits and the highly fractured and dissolved bedrock surface precludes locating the interface of these two layers with any confidence.

Seismic refraction data were readily inverted to layering parameters (velocities and thicknesses) by employing classical seismic refraction theory. The seismic velocities of the nearsurface deposits increased monotonically with depth, and there were always sizable velocity contrasts at the interfaces separating the near-surface layers, even at locations where alluvial and colluvial deposits rested on a highly fractured and dissolved bedrock surface. The only difficulty encountered in the seismic refraction profiling came as the result of having to detonate the energy 
source in the surficial, fine-grained loam and loess. These deposits appreciably damped the seismic energy.

All phases of this geophysical study - acquisition, processing, and interpretation - were quite satisfactory. However, the entire process could have been improved with downhole geological and geophysical control. Detailed samples and full suites of downhole geophysical logs from strategically located test borings, planned for later in this hydrogeological study, will allow reexamination and refinement of interpretation obtained from all geophysical data gathered to date.

Several important aspects of the hydrogeology of the Lautertal region have become clear on the basis of observations made during the course of this study. Groundwater recharge in the Lautertal is impeded by the widespread surficial layer of fine-grained loam and loess. This layer has a mean thickness of approximately $10 \mathrm{~m}$, and published hydraulic conductivity values for these types of materials are in the $10^{-5}$ to $10^{-9} \mathrm{~m} / \mathrm{s}$ range (Todd 1964). Given the considerable clay content of these deposits, their hydraulic conductivities likely fall near the low end of this range. In any event, infiltration of meteoric waters through these deposits appears to occur at a very low rate. Much of the meteoric water that falls directly on the Lautertal leaves as runoff. There are isolated places in the Lautertal where the layer of fine-grained loam and loess is not present. In those places, the coarse alluvial and colluvial deposits that fill the channels and other depressions in the bedrock surface are exposed.

The geologic map of the Velburg quadrangle (Meyer 1990) shows that the fluvial deposits known as the Schutzfelsschicten (Upper Cretaceous) are exposed in the western portion of the Lautertal. These deposits and the Pleistocene and Recent alluvial and colluvial deposits that occupy the channels and other depressions in the bedrock surface likely have hydraulic conductivities considerably higher than the loam and loess. As a result, these coarse deposits allow meteoric waters better access to the fractured and dissolved bedrock aquifers below. However, the rather small exposure of the coarse deposits probably limits the intake of meteoric waters.

The best access that the meteoric waters have to the main shallow bedrock aquifer in the Malm Formation appears to be through the exposed bedrock in the uplands away from the valleys. Some of the exposed bedrock in the uplands belongs to the Upper Kimmeridge (Epsilon) Member of the Malm Formation. This resistant rock caps the higher knolls in this region and does not have a fracture and dissolution porosity as great as the older rocks of the Middle Kimmeridge (Delta) Member of the Malm Formation, which are exposed closer to but still in the uplands away from the dry valleys. In the Lautertal region, rocks of the Middle Kimmeridge Member form more of the earth's surface than any other geological unit. These rocks also form the bedrock surface under many of the dry valleys like the Lautertal. If the rocks of the Middle Kimmeridge Member of the Malm Formation allow meteoric waters almost direct and unimpeded pathways to the main Malm aquifer, a hydraulic scenario is possible that would explain the turbid discharges observed in some of the perennial streams during and shortly after heavy rainfall. 


\section{Conclusions and Recommendations}

A geophysical study in the Lautertal at the Combat Maneuver Training Center in Hohenfels, Germany, was conducted to determine the shallow geological framework of a typical dry valley in the karstic environment of the southern Frankische Alb and, thereby, to gain insights into the role that the dry valleys in the region play in the shallow groundwater flow system. Not only was this goal achieved, but other areas were indicated where additional research is necessary to understand the total groundwater flow system.

The most significant conclusions of this study are as follows:

- A combination of carefully selected geophysical methods was successfully used to determine the shallow geological framework of a typical dry valley in this complex karstic environment.

- In dry valleys like the Lautertal, infiltration of meteoric waters into the subsurface is generally impeded by a surficial layer of fine-grained, lowhydraulic-conductivity loam and loess.

- Most groundwater recharge occurs in the uplands where the Middle Kimmeridge (Delta) Member of the Malm Formation (Jurassic) is widely exposed. These carbonate rocks are known to be susceptible to dissolution along structurally induced fractures and joints; thus, they offer ready access to the main shallow aquifers lower in the Malm Formation.

- The carbonate rocks of the Middle Kimmeridge Member of the Malm Formation appear to be closely associated with the localized occurrence of increased turbidity in perennial streams (such as the Lauterach) during or shortly after heavy rainfall.

On the basis of these conclusions, it is recommended that future efforts to understand the total shallow groundwater flow system of the Hohenfels region be focused on those areas where the bulk of groundwater recharge takes place, i.e., the uplands and the valley side slopes. The primary target of this research should be the Middle Kimmeridge Member of the Malm Formation.

Specific recommendations for future research are as follows:

- Detailed fracture pattern analysis of the carbonate rocks in the uplands should be given highest priority. Aerial photos, cave and spring inventories, and identification of catchments are all important. Ground and/or airborne timedomain electromagnetic surveying may prove useful in identifying fracture density and orientation in the subsurface. 
- Water wells within a specified distance of the Combat Maneuver Training Center should be inventoried. Knowledge of water levels, water chemistry, and the results from pump tests would be very useful in quantifying localized flow system parameters.

- Pertinent meteorological data should be gathered. Precipitation, evapotranspiration, and barometric pressure data have relevance to water budgets and the observed occurrences of turbidity in such perennial streams as the Lauterach.

- Chemical analysis of the waters of the Lauterach where turbidity has occurred should provide information on the source of groundwater inflow.

- High resolution surficial geophysical exploration data (ground-penetrating-radar and seismic-velocity profiling) should be collected near the point in the Lauterach where turbidity has occurred. Fractures and solution cavities in the upper bedrock should be targeted. 


\section{References}

Andres, G., and H. Wirth, 1985, Grundwassergleichenkarte von Bayern (1:500000), Bayerisches Landesamt für Wasserwirtschaft.

Apel, R., 1971, "Hydrogeologische Untersuchungen im Malmkarst der Südlichen und Mittleren Frankenalb," Geologica Bavarica 64:268-355, München.

Bayerisches Geologisches Landesamt, 1981, Geologische Karte von Bayern (1:500000), München, Germany.

Bayerisches Landesamt für Wasserwirtschaft, 1987, Die Grundwasserneufildung in Bayern Informationsberichte ISSN 0176-4217.

Dobrin, M.B., and C.H. Savit, 1988, Introduction to Geophysical Prospecting, McGraw-Hill Book Company, New York, N.Y.

Ebasco-Dorsch Consultants, Inc., 1990, Sanitary Landfill Investigations at Hohenfels Training Area, report prepared for the U.S. Army Engineer Division, Europe, CEEUD-ED-MC, Contract No. DACA 90-88-D-0058.

Freyberg, B.V., 1969, "Tektonische Karte der Frankischen Alb und ihrer Umgebung Erlanger," Geologische Abhandlungen 77, Erlangen.

Fuhrmann, D., 1977, Stratigraphische und Tektonische Untersuchungen auf der Kartenblättern Kastl und Velburg (1:25000), Dipl. Arb., University of Erlangen, Erlangen.

Heiland, C.A., 1968, Geophysical Exploration, Hafner Publishing Co., New York, N.Y.

Interpex Limited, 1988, Resix Plus User's Manual, Golden, Colo.

Lattman, L.A., and R.R. Parizek, 1964, "Relationship between Fracture Traces and the Occurrences of Groundwater in Carbonate Rocks," Journal of Hydrology 2:73-91.

Lindgren, B.W., 1960, Statistical Theory, MacMillan Company, New York, N.Y.

Meyer, R.F.K., 1990, Erlauterungen zur Geologische, Karte Blatt. Nr. 6736 Velburg (1:25000), Bayerisches Geologishes Landesamt, München, Germany. 
Schoger, H., 1992, Study of the Old Landfill, Hohenfels, Phase I, Wolf-Blumenthal Ingenieurbüro, Nürnberg, Germany, report prepared for Combat Maneuver Training Center, Hohenfels, Germany, Contract No. DACA 90-90-D-0053.

Telford, W.M., L.P. Geldart, R.E. Sheriff, and D.A. Keys, 1976, Applied Geophysics, Cambridge University Press, New York, N.Y.

- Todd, D. K., 1964, Groundwater Hydrology, John Wiley and Sons, Inc., New York, N.Y. 
- 
Appendix A:

Data for the Geophysical Studies in the Lautertal 
TABLE A.1 Surface Elevations in the Lautertal Study Area

\begin{tabular}{|c|c|c|c|}
\hline Nodal Coordinates & \multirow{2}{*}{$\frac{\begin{array}{c}\text { Surface Elevations } \\
\text { (meters above } \mathrm{ms}^{\mathrm{a}} \text { ) }\end{array}}{479.8}$} & Nodal Coordinates & \multirow{2}{*}{$\begin{array}{c}\begin{array}{c}\text { Surface Elevations } \\
\text { (meters above } \mathrm{ms}^{\mathrm{a}} \text { ) }\end{array} \\
460.0\end{array}$} \\
\hline 0258 & & 1256 & \\
\hline 0259 & 483.1 & 1257 & 450.7 \\
\hline & & 1258 & 442.4 \\
\hline 0358 & 481.9 & 1259 & 441.8 \\
\hline 0359 & 467.8 & 1260 & 447.9 \\
\hline 0360 & 474.6 & 1261 & 464.9 \\
\hline 0458 & 479.2 & 1356 & 447.3 \\
\hline 0459 & 462.6 & 1357 & 443.3 \\
\hline \multirow[t]{2}{*}{0460} & 466.8 & 1358 & 440.4 \\
\hline & & 1359 & 439.0 \\
\hline 0558 & 471.2 & 1360 & 441.4 \\
\hline 0559 & 459.0 & 1361 & 456.7 \\
\hline 0560 & 459.2 & 1362 & 470.5 \\
\hline 0656 & 483.0 & 1457 & 454.3 \\
\hline 0657 & 476.7 & 1458 & 450.1 \\
\hline 0658 & 462.5 & 1459 & 441.7 \\
\hline 0659 & 455.9 & 1460 & 440.6 \\
\hline 0660 & 455.8 & 1461 & 449.8 \\
\hline \multirow[t]{2}{*}{0661} & 466.0 & 1462 & 459.0 \\
\hline & & 1463 & 458.4 \\
\hline 0756 & 476.9 & & \\
\hline 0757 & 469.6 & 1557 & 476.0 \\
\hline 0758 & 460.9 & 1558 & 460.0 \\
\hline 0759 & 452.8 & 1559 & 447.3 \\
\hline 0760 & 451.8 & 1560 & 435.1 \\
\hline 0761 & 461.1 & 1561 & 441.7 \\
\hline \multirow[t]{2}{*}{0762} & 471.0 & 1562 & 448.8 \\
\hline & & 1563 & 454.5 \\
\hline 0857 & 462.7 & & \\
\hline 0858 & 457.0 & 1656 & 485.1 \\
\hline 0859 & 451.3 & 1657 & 473.4 \\
\hline 0860 & 449.7 & 1658 & 462.5 \\
\hline \multirow[t]{2}{*}{0861} & 462.3 & 1659 & 448.2 \\
\hline & & 1660 & 436.2 \\
\hline 0958 & 454.9 & 1661 & 435.8 \\
\hline 0959 & 451.9 & 1662 & 442.9 \\
\hline 0960 & 448.2 & 1663 & 454.6 \\
\hline \multirow[t]{2}{*}{0961} & 467.0 & & \\
\hline & & 1757 & 471.7 \\
\hline 1058 & 448.4 & 1758 & 459.5 \\
\hline 1059 & 450.4 & 1759 & 448.7 \\
\hline \multirow{2}{*}{1060} & 448.8 & 1760 & 437.2 \\
\hline & & 1761 & 432.2 \\
\hline 1158 & 444.2 & 1762 & 443.5 \\
\hline 1159 & 447.7 & 1763 & 456.9 \\
\hline 1160 & 448.8 & & \\
\hline
\end{tabular}


TABLE A.1 Cont.

\begin{tabular}{|c|c|c|c|}
\hline Nodal Coordinates & \multirow{2}{*}{$\begin{array}{c}\begin{array}{c}\text { Surface Elevations } \\
\text { (meters above } \mathrm{ms}^{\mathrm{a}} \text { ) }\end{array} \\
461.8\end{array}$} & Nodal Coordinates & \multirow{2}{*}{$\begin{array}{c}\begin{array}{c}\text { Surface Elevations } \\
\text { (meters above } \mathrm{msl}^{\mathrm{a}} \text { ) }\end{array} \\
453.6\end{array}$} \\
\hline 1857 & & 2458 & \\
\hline 1858 & 453.0 & 2459 & 441.0 \\
\hline 1859 & 444.5 & 2460 & 431.0 \\
\hline 1860 & 435.3 & 2461 & 420.8 \\
\hline 1861 & 430.3 & 2462 & 432.9 \\
\hline 1862 & 440.8 & & \\
\hline 1863 & 454.8 & 2555 & 462.8 \\
\hline \multirow[t]{2}{*}{1864} & 479.3 & 2556 & 452.9 \\
\hline & & 2557 & 461.9 \\
\hline 1957 & 454.9 & 2558 & 450.4 \\
\hline 1958 & n.m.b & 2559 & 437.8 \\
\hline 1959 & 443.3 & 2560 & 429.7 \\
\hline 1960 & 435.4 & 2561 & 419.1 \\
\hline 1961 & 428.7 & & \\
\hline 1962 & 438.4 & 2655 & 445.7 \\
\hline 1963 & 451.6 & 2656 & 442.9 \\
\hline \multirow[t]{2}{*}{1964} & 467.9 & 2657 & 453.5 \\
\hline & & 2658 & 443.5 \\
\hline 2058 & n.m. & 2659 & 434.8 \\
\hline 2059 & 440.3 & 2660 & 428.1 \\
\hline 2060 & 436.8 & 2661 & 418.3 \\
\hline 2061 & 428.0 & & \\
\hline 2062 & 439.3 & 2754 & 440.2 \\
\hline \multirow[t]{2}{*}{2063} & 453.4 & 2755 & 439.3 \\
\hline & & 2756 & 435.1 \\
\hline 2158 & 435.3 & 2757 & 441.6 \\
\hline 2159 & 431.3 & 2758 & 437.4 \\
\hline 2160 & 429.7 & 2759 & 430.7 \\
\hline 2161 & 426.2 & 2760 & 422.2 \\
\hline 2162 & 438.5 & & \\
\hline \multirow[t]{2}{*}{2163} & 454.7 & 2853 & 436.9 \\
\hline & & 2854 & 434.9 \\
\hline 2257 & 452.8 & 2855 & 437.8 \\
\hline 2258 & 449.2 & 2856 & 432.2 \\
\hline 2259 & 440.6 & 2857 & 433.4 \\
\hline 2260 & 426.6 & 2858 & 432.4 \\
\hline 2261 & 425.0 & 2859 & 425.0 \\
\hline 2262 & 437.6 & 2860 & 415.8 \\
\hline 2357 & 460.2 & 2953 & 431.5 \\
\hline 2358 & 451.4 & 2954 & 430.5 \\
\hline 2359 & 440.9 & 2955 & 434.8 \\
\hline 2360 & 426.9 & 2956 & 430.1 \\
\hline 2361 & 423.5 & 2957 & 430.1 \\
\hline \multirow[t]{2}{*}{ - 2362} & 435.3 & 2958 & 429.2 \\
\hline & & 2959 & 421.0 \\
\hline 2456 & 467.4 & 2960 & 411.0 \\
\hline 2457 & 463.5 & & \\
\hline
\end{tabular}


TABLE A.1 Cont.

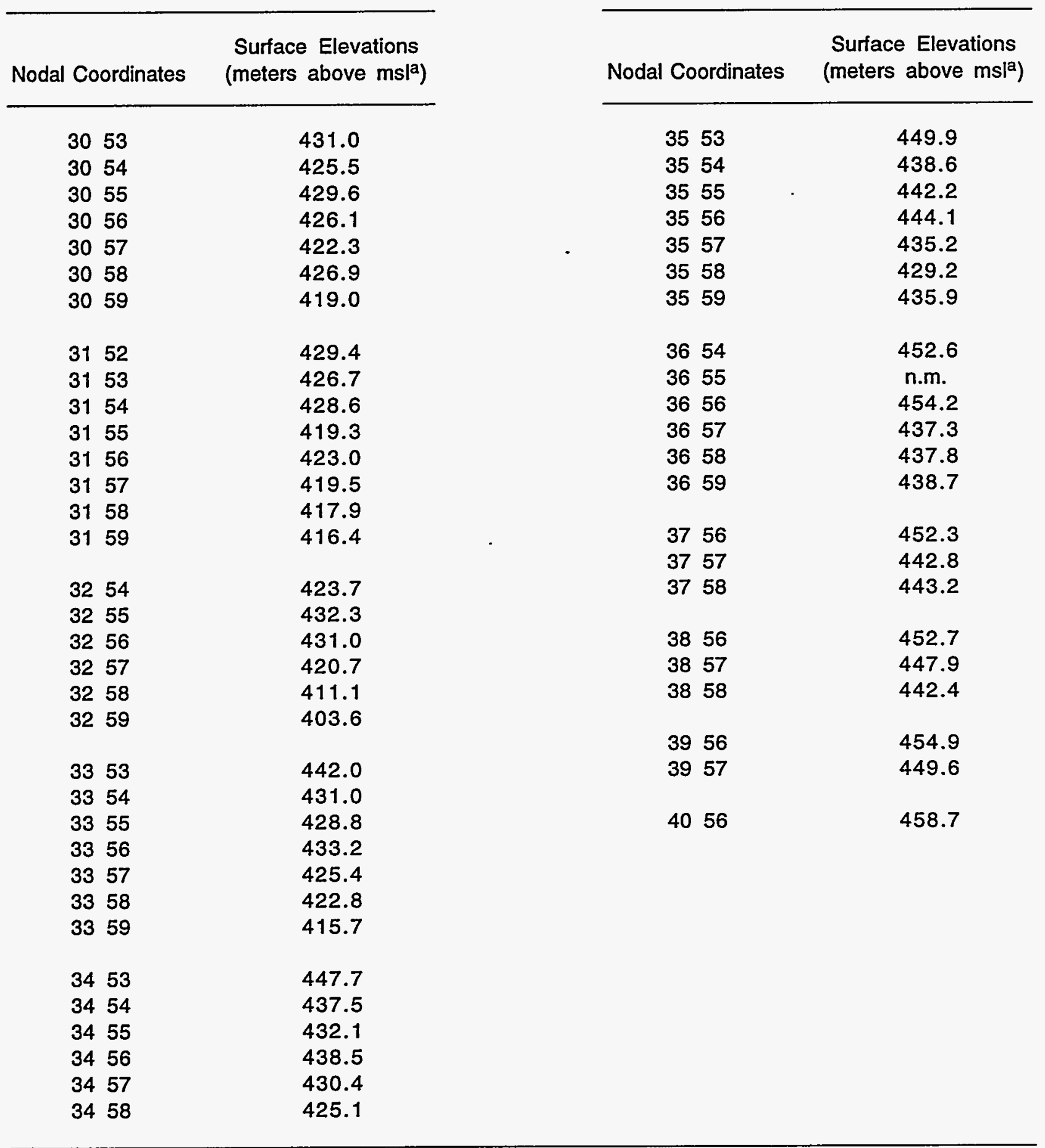

$\mathrm{a}_{\mathrm{msl}}=$ mean sea level.

${ }^{b}$ n.m. = no measurement. 
TABLE A.2 Electromagnetic Surveying Data

\begin{tabular}{|c|c|c|c|}
\hline \multirow[b]{2}{*}{ Nodal Coordinates } & \multicolumn{3}{|c|}{$\begin{array}{l}\text { Apparent Conductivity at } \\
\text { Transmitter-Receiver Separation (mmho/m) }\end{array}$} \\
\hline & $10 \mathrm{~m}$ & $20 \mathrm{~m}$ & $40 \mathrm{~m}$ \\
\hline 0258 & 7.1 & 5.5 & 1.9 \\
\hline 0259 & 6.8 & 5.4 & 2.1 \\
\hline 0358 & 3.9 & 4.4 & 1.3 \\
\hline 0359 & 11.5 & 10.5 & 5.7 \\
\hline 0360 & 12.0 & 8.5 & 5.5 \\
\hline 0458 & 9.3 & 9.2 & 8.2 \\
\hline 0459 & 14.0 & 12.0 & 7.2 \\
\hline 0460 & 2.7 & 2.65 & 1.1 \\
\hline 0558 & 7.1 & 5.5 & 1.9 \\
\hline 0559 & 12.0 & 9.4 & 2.9 \\
\hline 0560 & 3.9 & 4.0 & 1.6 \\
\hline 0656 & 8.8 & 7.7 & 3.4 \\
\hline 0657 & 6.0 & 5.8 & 1.5 \\
\hline 0658 & 11.0 & 6.2 & 2.0 \\
\hline 0659 & 6.6 & 4.3 & 0.3 \\
\hline 0660 & 7.4 & 4.8 & 2.0 \\
\hline 0661 & 1.4 & 1.0 & 0.1 \\
\hline 0756 & 6.8 & 5.9 & 3.4 \\
\hline 0757 & 1.4 & 1.5 & 0.2 \\
\hline 0758 & 6.3 & 3.4 & 0.4 \\
\hline 0759 & 2.5 & 1.7 & 0.6 \\
\hline 0760 & 6.65 & 4.6 & 0.9 \\
\hline 0761 & 1.8 & 1.2 & 0.5 \\
\hline 0762 & 7.1 & 4.9 & 1.8 \\
\hline 0857 & 11.0 & 9.0 & 3.5 \\
\hline 0858 & 18.0 & 14.5 & 5.5 \\
\hline 0859 & 10.0 & 8.0 & 3.0 \\
\hline 0860 & 14.5 & 11.5 & 0.5 \\
\hline 0861 & 1.4 & 1.4 & 0.9 \\
\hline 0958 & 17.5 & 14.0 & 8.5 \\
\hline 0959 & 12.5 & 12.0 & 5.9 \\
\hline 0960 & 15.0 & 12.0 & 5.25 \\
\hline 0961 & 1.2 & 0.9 & 0.6 \\
\hline 1058 & 15.5 & 12.5 & 6.0 \\
\hline 1059 & 16.0 & 13.0 & 6.8 \\
\hline 1060 & 11.2 & 6.5 & 2.9 \\
\hline
\end{tabular}


TABLE A.2 Cont.

\begin{tabular}{|c|c|c|c|}
\hline \multirow[b]{2}{*}{ Nodal Coordinates } & \multicolumn{3}{|c|}{$\begin{array}{c}\text { Apparent Conductivity at } \\
\text { Transmitter-Receiver Separation (mmho/m) }\end{array}$} \\
\hline & $10 \mathrm{~m}$ & $20 \mathrm{~m}$ & $40 \mathrm{~m}$ \\
\hline 1158 & 14.0 & 11.5 & 6.0 \\
\hline 1159 & 11.5 & 10.0 & 4.4 \\
\hline 1160 & 4.9 & 5.1 & 4.2 \\
\hline 1256 & 8.5 & 7.0 & 4.0 \\
\hline 1257 & 5.8 & 5.3 & 2.0 \\
\hline 1258 & 12.0 & 9.0 & 3.5 \\
\hline 1259 & 11.0 & 7.0 & 1.0 \\
\hline 1260 & 5.1 & 3.8 & 1.2 \\
\hline 1261 & 1.0 & 0.9 & 1.0 \\
\hline 1356 & 9.5 & 7.0 & 2.5 \\
\hline 1357 & 17.0 & 15.0 & 7.0 \\
\hline 1358 & 5.6 & 4.2 & 4.1 \\
\hline 1359 & 25.0 & 19.0 & 12.0 \\
\hline 1360 & 5.0 & 4.3 & 3.2 \\
\hline 1361 & 10.5 & 6.5 & 5.0 \\
\hline 1362 & 2.1 & 1.8 & 0.8 \\
\hline 1457 & 1.8 & 2.0 & $0 . \dot{8}$ \\
\hline 1458 & 0.9 & 1.5 & 1.2 \\
\hline 1459 & 3.4 & 3.0 & 3.0 \\
\hline 1460 & 2.6 & 2.9 & 1.2 \\
\hline 1461 & 4.5 & 3.5 & 1.5 \\
\hline 1462 & 5.0 & 3.5 & 1.5 \\
\hline 1463 & 9.0 & 7.5 & 3.5 \\
\hline 1557 & 2.0 & 1.5 & 0.1 \\
\hline 1558 & 1.5 & $1.5^{\circ}$ & 0.5 \\
\hline 1559 & 2.0 & 2.5 & 1.0 \\
\hline 1560 & 17.5 & 13.5 & 6.0 \\
\hline 1561 & 3.0 & 4.0 & 0.5 \\
\hline 1562 & 12.0 & 9.5 & 5.0 \\
\hline 1563 & 25.0 & 19.0 & 9.0 \\
\hline 1656 & 1.0 & 1.0 & 0.6 \\
\hline 1657 & 1.5 & 1.0 & 2.5 \\
\hline 1658 & 1.5 & 1.0 & 1.0 \\
\hline 1659 & 4.5 & 4.0 & 2.5 \\
\hline 1660 & 5.5 & 5.0 & 3.0 \\
\hline 1661 & 8.0 & 7.5 & 5.0 \\
\hline 1662 & 15.0 & 13.0 & 3.5 \\
\hline 1757 & 4.0 & 4.0 & 1.5 \\
\hline 1758 & 2.5 & 2.5 & 1.5 \\
\hline 1759 & 2.5 & 2.5 & 2.0 \\
\hline
\end{tabular}


TABLE A.2 Cont.

\begin{tabular}{|c|c|c|c|}
\hline \multirow[b]{2}{*}{ Nodal Coordinates } & \multicolumn{3}{|c|}{$\begin{array}{l}\text { Apparent Conductivity at } \\
\text { Transmitter-Receiver Separation }(\mathrm{mmho} / \mathrm{m})\end{array}$} \\
\hline & $10 \mathrm{~m}$ & $20 \mathrm{~m}$ & $40 \mathrm{~m}$ \\
\hline 1760 & 3.5 & 4.0 & 3.0 \\
\hline 1761 & 14.0 & 12.5 & 7.0 \\
\hline 1762 & 3.0 & 2.5 & 1.0 \\
\hline 1763 & 3.0 & 2.0 & 2.0 \\
\hline 1857 & 7.0 & 6.5 & 4.5 \\
\hline 1858 & 10.5 & 8.0 & 6.0 \\
\hline 1859 & 5.0 & 6.0 & 5.0 \\
\hline 1860 & 18.0 & 15.5 & 5.0 \\
\hline 1861 & 18.0 & 14.5 & 6.0 \\
\hline 1862 & 6.0 & 4.5 & 1.0 \\
\hline 1863 & 5.0 & 4.0 & 2.0 \\
\hline 1864 & 2.0 & 1.5 & 1.0 \\
\hline 1957 & 15.0 & 14.5 & 6.0 \\
\hline 1958 & 16.5 & 12.0 & 9.0 \\
\hline 1959 & 9.0 & 8.0 & 4.5 \\
\hline 1960 & 14.5 & 10.5 & 7.0 \\
\hline 1961 & 13.5 & 12.0 & 8.5 \\
\hline 1962 & 3.5 & 2.25 & 1.5 \\
\hline 1963 & 3.0 & 2.0 & 1.0 \\
\hline 1964 & 2.0 & 1.5 & 1.5 \\
\hline 2059 & 18.0 & 12.0 & 9.0 \\
\hline 2060 & 12.0 & 9.0 & 1.0 \\
\hline 2061 & 11.0 & 8.5 & 5.0 \\
\hline 2062 & 4.0 & 3.0 & 2.0 \\
\hline 2063 & 2.0 & 1.5 & 1.5 \\
\hline 2158 & 7.25 & 7.0 & 3.5 \\
\hline 2159 & 9.0 & 8.0 & 7.0 \\
\hline 2160 & 17.0 & 11.0 & 7.0 \\
\hline 2161 & 10.5 & 7.5 & 3.5 \\
\hline 2162 & 3.0 & 2.5 & 1.0 \\
\hline 2163 & 5.0 & 4.0 & 2.0 \\
\hline 2257 & 4.0 & 3.0 & 1.0 \\
\hline 2258 & 3.0 & 2.5 & 1.0 \\
\hline 2259 & 3.8 & 2.6 & 1.1 \\
\hline 2260 & 7.5 & 7.5 & 8.0 \\
\hline 2261 & 12.0 & 11.0 & 6.5 \\
\hline 2262 & 1.4 & 1.4 & 1.4 \\
\hline 2357 & 2.0 & 2.0 & 1.5 \\
\hline 2358 & $\cdot 5.5$ & 3.0 & 4.0 \\
\hline 2359 & 5.0 & 4.5 & 4.5 \\
\hline
\end{tabular}


TABLE A.2 Cont.

\begin{tabular}{|c|c|c|c|}
\hline \multirow[b]{2}{*}{ Nodal Coordinates } & \multicolumn{3}{|c|}{$\begin{array}{l}\text { Apparent Conductivity at } \\
\text { Transmitter-Receiver Separation }(\mathrm{mmho} / \mathrm{m})\end{array}$} \\
\hline & $10 \mathrm{~m}$ & $20 \mathrm{~m}$ & $40 \mathrm{~m}$ \\
\hline 2360 & 17.5 & 15.0 & 9.5 \\
\hline 2361 & 11.0 & 9.5 & 7.0 \\
\hline 2362 & 3.9 & 3.0 & 1.5 \\
\hline 2456 & 1.6 & 1.4 & 1.2 \\
\hline 2457 & 4.5 & 4.3 & 0.4 \\
\hline 2458 & 1.3 & 1.4 & 0.3 \\
\hline 2459 & 5.1 & 4.1 & 1.6 \\
\hline 2460 & 3.0 & 3.5 & 2.5 \\
\hline 2461 & 13.0 & 11.5 & 7.0 \\
\hline 2462 & 2.8 & 2.8 & 1.9 \\
\hline 2555 & 2.1 & 2.5 & 2.6 \\
\hline 2556 & 2.9 & 3.3 & 1.6 \\
\hline 2557 & 8.0 & 5.0 & 0.3 \\
\hline 2558 & 5.5 & 6.2 & 2.0 \\
\hline 2559 & 4.3 & 3.5 & 0.5 \\
\hline 2560 & 2.5 & 3.2 & 1.4 \\
\hline 2561 & 12.0 & 11.5 & 5.0 \\
\hline 2655 & 7.4 & 5.6 & 2.5 \\
\hline 2656 & 13.5 & 10.5 & 5.0 \\
\hline 2657 & 11.0 & 6.0 & 1.5 \\
\hline 2658 & 15.5 & 11.0 & 7.0 \\
\hline 2659 & 18.0 & 13.5 & 5.0 \\
\hline 2660 & 7.0 & 6.0 & 1.5 \\
\hline 2661 & 13.0 & 10.0 & 6.0 \\
\hline 2754 & 24.0 & 20.0 & 8.0 \\
\hline 2755 & 12.0 & 9.0 & 4.0 \\
\hline 2756 & 23.0 & 18.0 & 9.0 \\
\hline 2757 & 17.0 & 14.5 & 8.5 \\
\hline 2758 & 18.0 & 13.5 & 7.0 \\
\hline 2759 & 7.0 & 3.0 & 1.5 \\
\hline 2760 & 18.0 & 14.0 & 9.5 \\
\hline 2853 & 22.0 & 13.5 & 8.0 \\
\hline 2854 & 19.5 & 17.0 & 11.0 \\
\hline 2855 & 18.0 & 17.0 & 9.0 \\
\hline 2856 & 20.0 & 16.5 & \\
\hline 2857 & 18.0 & 13.5 & 7.0 \\
\hline 2858 & 22.0 & 17.0 & 10.0 \\
\hline 2859 & 18.0 & 14.0 & 8.0 \\
\hline 2860 & 9.5 & 9.0 & 4.0 \\
\hline
\end{tabular}


TABLE A.2 Cont.

\begin{tabular}{|c|c|c|c|}
\hline \multirow[b]{2}{*}{ Nodal Coordinates } & \multicolumn{3}{|c|}{$\begin{array}{l}\text { Apparent Conductivity at } \\
\text { Transmitter-Receiver Separation (mmho/m) }\end{array}$} \\
\hline & $10 \mathrm{~m}$ & $20 \mathrm{~m}$ & $40 \mathrm{~m}$ \\
\hline 2953 & 16.0 & 15.0 & 11.5 \\
\hline 2954 & 21.0 & 18.0 & 10.0 \\
\hline 2955 & 22.0 & 17.5 & 9.0 \\
\hline 2956 & 18.0 & 15.0 & 7.0 \\
\hline 2957 & 26.0 & 23.0 & 13.0 \\
\hline 2958 & 29.0 & 25.0 & 16.0 \\
\hline 2959 & 18.0 & 13.0 & 8.0 \\
\hline 3053 & 16.0 & 18.0 & 11.0 \\
\hline 3054 & 19.5 & 18.0 & 11.0 \\
\hline 3055 & 16.5 & 14.0 & 8.0 \\
\hline 3056 & 6.5 & 4.5 & 4.0 \\
\hline 3057 & 11.0 & 9.5 & 6.0 \\
\hline 3058 & 19.0 & 16.5 & 11.0 \\
\hline 3059 & 11.0 & 9.0 & 6.0 \\
\hline 3152 & 18.0 & 15.0 & 7.0 \\
\hline 3153 & 11.0 & 10.0 & 7.5 \\
\hline 3154 & 12.0 & 8.5 & 7.0 \\
\hline 3155 & 13.0 & 9.0 & 7.0 \\
\hline 3156 & $3: 0$ & 4.0 & 2.5 \\
\hline 3157 & 6.0 & 5.0 & 2.0 \\
\hline 3158 & 10.0 & 9.0 & 5.0 \\
\hline 3159 & 5.0 & 5.0 & 3.0 \\
\hline 3254 & 12.5 & 10.0 & 6.5 \\
\hline 3255 & 4.5 & 3.5 & 3.0 \\
\hline 3256 & 7.0 & 5.5 & 3.5 \\
\hline 3257 & 3.5 & 3.5 & 2.5 \\
\hline 3258 & 12.5 & 8.0 & 4.5 \\
\hline 3259 & 6.0 & 5.0 & 4.0 \\
\hline 3353 & 7.5 & 6.0 & 1.5 \\
\hline 3354 & 11.5 & 9.0 & 6.0 \\
\hline 3355 & 11.5 & 9.0 & 6.5 \\
\hline 3356 & 8.0 & 7.5 & 3.0 \\
\hline 3357 & 18.0 & 14.0 & 7.5 \\
\hline 3358 & 3.5 & 4.5 & 2.0 \\
\hline 3359 & 4.0 & 3.8 & 4.0 \\
\hline 3453 & 8.5 & 6.0 & 2.0 \\
\hline 3454 & 7.5 & 5.5 & 3.5 \\
\hline 3455 & 23.0 & 20.5 & 12.5 \\
\hline 3456 & 10.0 & 8.5 & 4.5 \\
\hline 3457 & 11.5 & 8.0 & 4.5 \\
\hline
\end{tabular}


TABLE A.2 Cont.

Apparent Conductivity at

Transmitter-Receiver Separation (mmho/m)

\begin{tabular}{|c|c|c|c|}
\hline Nodal Coordinates & $10 \mathrm{~m}$ & $20 \mathrm{~m}$ & $40 \mathrm{~m}$ \\
\hline 3458 & 7.0 & 8.0 & 3.5 \\
\hline 3553 & -7.5 & 6.5 & 2.0 \\
\hline 3554 & 9.0 & 8.0 & 3.0 \\
\hline 3555 & 8.5 & 8.0 & 4.0 \\
\hline 3556 & 4.0 & 4.0 & 3.5 \\
\hline 3557 & 12.0 & 8.0 & 5.0 \\
\hline 3558 & 16.6 & 13.5 & 7.0 \\
\hline 3559 & 8.0 & 7.0 & 4.0 \\
\hline 3656 & 1.8 & 2.6 & 1.5 \\
\hline 3657 & 14.5 & 11.0 & 6.0 \\
\hline 3658 & 6.0 & 7.0 & 4.5 \\
\hline 3659 & 7.0 & 8.0 & 4.0 \\
\hline 3756 & 12.0 & 6.0 & 3.5 \\
\hline 3757 & 7.5 & 6.0 & 4.5 \\
\hline 3758 & 6.5 & 7.0 & 3.0 \\
\hline 3856 & 7.0 & 5.5 & 2.5 \\
\hline 3857 & 22.0 & & \\
\hline 3858 & 17.0 & 14.5 & 9.0 \\
\hline 3956 & 12.5 & 13.0 & 4.5 \\
\hline 3957 & 13.0 & 11.0 & 5.0 \\
\hline 4056 & 12.0 & 8.0 & 4.0 \\
\hline
\end{tabular}


TABLE A.3 Results of Inversion of Vertical Electrical Sounding Data

\begin{tabular}{|c|c|c|c|}
\hline Nodal Coordinates & $\begin{array}{l}\text { Surface Elevation } \\
\text { (meters above } \mathrm{msl}^{\mathrm{a}} \text { ) }\end{array}$ & $\begin{array}{c}\text { Layer Resistivity } \\
(\Omega-m)\end{array}$ & $\begin{array}{l}\text { Layer Thickness } \\
\text { (m) }\end{array}$ \\
\hline 0259 & 483.1 & $\begin{array}{r}93 \\
531\end{array}$ & 6.47 \\
\hline 0360 & 474.6 & $\begin{array}{r}60 \\
661\end{array}$ & 4.78 \\
\hline 0459 & 462.6 & $\begin{array}{r}51 \\
1104\end{array}$ & 9.91 \\
\hline 0559 & 459.0 & $\begin{array}{r}57 \\
501\end{array}$ & 5.94 \\
\hline 0560 & 459.2 & $\begin{array}{l}129 \\
252 \\
985\end{array}$ & $\begin{array}{r}2.49 \\
15.51\end{array}$ \\
\hline 0659 & 455.9 & $\begin{array}{r}48 \\
119 \\
7367\end{array}$ & $\begin{array}{l}4.11 \\
7.24\end{array}$ \\
\hline 0660 & 455.8 & $\begin{array}{r}13 \\
4209 \\
74 \\
14,820\end{array}$ & $\begin{array}{l}0.72 \\
0.58 \\
7.85\end{array}$ \\
\hline 0661 & 466.0 & $\begin{array}{l}474 \\
767\end{array}$ & 5.34 \\
\hline 0759 & 452.8 & $\begin{array}{r}1365 \\
426 \\
1125\end{array}$ & $\begin{array}{r}0.90 \\
37.22\end{array}$ \\
\hline 0760 & 451.8 & $\begin{array}{l}121 \\
982\end{array}$ & 10.34 \\
\hline 0761 & 461.1 & $\begin{array}{r}2593 \\
171 \\
1231\end{array}$ & $\begin{array}{l}2.06 \\
3.17\end{array}$ \\
\hline 0762 & 471.0 & $\begin{array}{r}19 \\
1121\end{array}$ & 0.72 \\
\hline 0859 & 451.3 & $\begin{array}{r}66 \\
5010\end{array}$ & 11.21 \\
\hline 0860 & 449.7 & $\begin{array}{r}30 \\
113 \\
1440\end{array}$ & $\begin{array}{r}2.25 \\
10.60\end{array}$ \\
\hline
\end{tabular}


TABLE A.3 Cont.

\begin{tabular}{|c|c|c|c|}
\hline Nodal Coordinates & $\begin{array}{l}\text { Surface Elevation } \\
\text { (meters above } \mathrm{ms}^{\mathrm{a}} \text { ) }\end{array}$ & $\begin{array}{l}\text { Layer Resistivity } \\
(\Omega-m)\end{array}$ & $\begin{array}{l}\text { Layer Thickness } \\
(\mathrm{m})\end{array}$ \\
\hline 0861 & 462.3 & $\begin{array}{r}831 \\
3172 \\
781\end{array}$ & $\begin{array}{l}3.55 \\
4.01\end{array}$ \\
\hline 0959 & 451.9 & $\begin{array}{r}47 \\
435\end{array}$ & 5.96 \\
\hline 0960 & 448.2 & $\begin{array}{r}50 \\
1043\end{array}$ & 8.92 \\
\hline 1058 & 448.4 & $\begin{array}{r}38 \\
790\end{array}$ & 6.13 \\
\hline 1059 & 450.4 & $\begin{array}{r}32 \\
463\end{array}$ & 3.50 \\
\hline 1060 & 448.8 & $\begin{array}{r}127 \\
1117\end{array}$ & 19.48 \\
\hline 1158 & 444.2 & $\begin{array}{r}49 \\
150 \\
1246\end{array}$ & $\begin{array}{l}6.58 \\
3.37\end{array}$ \\
\hline 1159 & 447.2 & $\begin{array}{r}4 \\
2809\end{array}$ & 0.90 \\
\hline 1160 & 448.8 & $\begin{array}{r}179 \\
1027\end{array}$ & 23.98 \\
\hline 1258 & 442.4 & $\begin{array}{r}5 \\
997\end{array}$ & 1.46 \\
\hline 1259 & 441.8 & $\begin{array}{r}29 \\
1880 \\
32 \\
61,560\end{array}$ & $\begin{array}{l}3.38 \\
1.86 \\
8.21\end{array}$ \\
\hline 1260 & 447.9 & $\begin{array}{l}369 \\
589 \\
373\end{array}$ & $\begin{array}{l}8.25 \\
7.42\end{array}$ \\
\hline 1261 & 464.9 & $\begin{array}{r}575 \\
2283 \\
591\end{array}$ & $\begin{array}{r}8.72 \\
15.74\end{array}$ \\
\hline 1356 & 447.3 & $\begin{array}{r}71 \\
908\end{array}$ & 3.54 \\
\hline 1357 & 443.3 & $\begin{array}{r}43 \\
1377\end{array}$ & 8.25 \\
\hline
\end{tabular}


TABLE A.3 Cont.

\begin{tabular}{|c|c|c|c|}
\hline Nodal Coordinates & $\begin{array}{l}\text { Surface Elevation } \\
\text { (meters above } \mathrm{ms}^{\mathrm{a}} \text { ) }\end{array}$ & $\begin{array}{c}\text { Layer Resistivity } \\
(\Omega-m)\end{array}$ & $\begin{array}{l}\text { Layer Thickness } \\
\text { (m) }\end{array}$ \\
\hline 1358 & 440.4 & $\begin{array}{r}91 \\
9580\end{array}$ & 11.22 \\
\hline 1359 & 439.0 & $\begin{array}{r}30 \\
4940\end{array}$ & 14.31 \\
\hline 1360 . & 441.4 & $\begin{array}{l}134 \\
425\end{array}$ & 18.98 \\
\hline 1361 & 456.7 & $\begin{array}{r}33 \\
1403\end{array}$ & 1.59 \\
\hline 1458 & 450.1 & $\begin{array}{r}153 \\
1132\end{array}$ & 1.32 \\
\hline 1459 & 441.7 & $\begin{array}{r}154 \\
2957 \\
50 \\
5374\end{array}$ & $\begin{array}{l}1.11 \\
2.73 \\
8.21\end{array}$ \\
\hline 1460 & 440.6 & $\begin{array}{r}98 \\
4205 \\
40 \\
1769\end{array}$ & $\begin{array}{l}1.26 \\
2.83 \\
7.03\end{array}$ \\
\hline 1461 & 449.8 & $\begin{array}{r}94 \\
645\end{array}$ & 2.52 \\
\hline 1559 & 447.3 & $\begin{array}{l}812 \\
278 \\
809\end{array}$ & $\begin{array}{r}5.05 \\
12.30\end{array}$ \\
\hline 1560 & 435.1 & $\begin{array}{r}39 \\
11,369\end{array}$ & 10.52 \\
\hline 1561 & 441.7 & 467 & \\
\hline 1562 & 448.8 & $\begin{array}{r}43 \\
77 \\
34,080\end{array}$ & $\begin{array}{r}2.40 \\
18.18\end{array}$ \\
\hline 1563 & 454.5 & $\begin{array}{r}21 \\
13,970\end{array}$ & 8.12 \\
\hline 1659 & 448.2 & $\begin{array}{r}229 \\
4047\end{array}$ & 22.84 \\
\hline
\end{tabular}


TABLE A.3 Cont.

\begin{tabular}{|c|c|c|c|}
\hline Nodal Coordinates & $\begin{array}{l}\text { Surface Elevation } \\
\text { (meters above msla) }\end{array}$ & $\begin{array}{l}\text { Layer Resistivity } \\
\qquad(\Omega-m)\end{array}$ & $\begin{array}{l}\text { Layer Thickness } \\
\text { (m) }\end{array}$ \\
\hline 1660 & 436.2 & $\begin{array}{r}30 \\
363 \\
10,500\end{array}$ & $\begin{array}{r}1.46 \\
67.64\end{array}$ \\
\hline 1661 & 435.8 & $\begin{array}{r}86 \\
271 \\
10,580\end{array}$ & $\begin{array}{r}4.23 \\
61.67\end{array}$ \\
\hline 1757 & 471.7 & $\begin{array}{r}242 \\
2388 \\
100\end{array}$ & $\begin{array}{r}5.29 \\
15.81\end{array}$ \\
\hline 1759 & 448.7 & $\begin{array}{r}684 \\
145 \\
1300\end{array}$ & $\begin{array}{r}13.32 \\
8.40\end{array}$ \\
\hline 1760 & 437.2 & $\begin{array}{r}247 \\
555 \\
143 \\
8025\end{array}$ & $\begin{array}{r}4.28 \\
13.69 \\
28.24\end{array}$ \\
\hline 1761 & 432.2 & $\begin{array}{r}46 \\
741\end{array}$ & 7.03 \\
\hline 1762 & 443.5 & $\begin{array}{l}183 \\
981 \\
347 \\
725\end{array}$ & $\begin{array}{r}0.67 \\
9.71 \\
34.27\end{array}$ \\
\hline 1763 & 456.9 & $\begin{array}{l}416 \\
986\end{array}$ & 10.45 \\
\hline 1858 & 453.0 & $\begin{array}{l}134 \\
951\end{array}$ & 16.30 \\
\hline 1860 & 435.3 & $\begin{array}{r}29 \\
549\end{array}$ & 5.04 \\
\hline 1861 & 430.3 & $\begin{array}{r}30 \\
418 \\
1912\end{array}$ & $\begin{array}{r}5.67 \\
17.16\end{array}$ \\
\hline 1862 & 440.8 & $\begin{array}{r}54 \\
689\end{array}$ & 1.05 \\
\hline 1959 & 443.3 & $\begin{array}{r}49 \\
192 \\
423\end{array}$ & $\begin{array}{r}2.65 \\
19.76\end{array}$ \\
\hline
\end{tabular}


TABLE A.3 Cont.

\begin{tabular}{|c|c|c|c|}
\hline Nodal Coordinates & $\begin{array}{l}\text { Surface Elevation } \\
\text { (meters above } \mathrm{ms}^{\mathrm{a}} \text { ) }\end{array}$ & $\begin{array}{c}\text { Layer Resistivity } \\
(\Omega-m)\end{array}$ & $\begin{array}{l}\text { Layer Thickness } \\
\text { (m) }\end{array}$ \\
\hline 1960 & 435.4 & $\begin{array}{r}22 \\
156 \\
1102\end{array}$ & $\begin{array}{r}1.25 \\
20.81\end{array}$ \\
\hline 1961 & 428.7 & $\begin{array}{r}21 \\
306 \\
1181\end{array}$ & $\begin{array}{r}1.33 \\
43.06\end{array}$ \\
\hline 1962 & 438.4 & $\begin{array}{r}100 \\
2583 \\
137 \\
1222\end{array}$ & $\begin{array}{r}1.17 \\
3.45 \\
12.22\end{array}$ \\
\hline 2059 & 440.3 & $\begin{array}{r}17 \\
6850\end{array}$ & 7.10 \\
\hline 2060 & 436.8 & $\begin{array}{r}35 \\
892\end{array}$ & 8.14 \\
\hline 2061 & 428.0 & $\begin{array}{r}79 \\
467\end{array}$ & 7.12 \\
\hline 2062 & 439.3 & $\begin{array}{r}72 \\
183\end{array}$ & 3.33 \\
\hline 2158 & 435.3 & $\begin{array}{r}26 \\
747 \\
39 \\
4282\end{array}$ & $\begin{array}{l}1.28 \\
3.43 \\
9.11\end{array}$ \\
\hline 2159 & 431.3 & $\begin{array}{r}84 \\
258 \\
724\end{array}$ & $\begin{array}{r}3.98 \\
39.39\end{array}$ \\
\hline 2160 & 429.7 & $\begin{array}{r}22 \\
992\end{array}$ & 4.19 \\
\hline 2161 & 426.2 & $\begin{array}{r}66 \\
535\end{array}$ & 7.03 \\
\hline 2163 & 454.7 & $\begin{array}{r}73 \\
1640\end{array}$ & 1.04 \\
\hline 2257 & 460.2 & $\begin{array}{r}302 \\
2061\end{array}$ & 10.92 \\
\hline 2258 & 449.2 & $\begin{array}{l}289 \\
550\end{array}$ & 4.74 \\
\hline
\end{tabular}


TABLE A.3 Cont.

\begin{tabular}{|c|c|c|c|}
\hline Nodal Coordinates & $\begin{array}{l}\text { Surface Elevation } \\
\text { (meters above } \mathrm{ms}^{\mathrm{a}} \text { ) }\end{array}$ & $\begin{array}{c}\text { Layer Resistivity } \\
(\Omega-\mathrm{m})\end{array}$ & $\begin{array}{l}\text { Layer Thickness } \\
(\mathrm{m})\end{array}$ \\
\hline 2259 & 440.6 & $\begin{array}{r}133 \\
3669 \\
350\end{array}$ & $\begin{array}{l}3.05 \\
1.21\end{array}$ \\
\hline 2260 & 426.6 & $\begin{array}{r}66 \\
220 \\
397\end{array}$ & $\begin{array}{l}3.05 \\
1.22\end{array}$ \\
\hline 2261 & 425.0 & $\begin{array}{r}56 \\
147 \\
521\end{array}$ & $\begin{array}{l}5.95 \\
6.23\end{array}$ \\
\hline 2262 & 437.6 & $\begin{array}{r}261 \\
1044 \\
509\end{array}$ & $\begin{array}{r}1.69 \\
13.64\end{array}$ \\
\hline 2358 & 451.4 & $\begin{array}{r}260 \\
3258\end{array}$ & 24.34 \\
\hline 2359 & 440.9 & $\begin{array}{r}124 \\
6109 \\
8 \\
1142\end{array}$ & $\begin{array}{l}2.05 \\
1.92 \\
1.12\end{array}$ \\
\hline 2360 & 426.9 & $\begin{array}{r}46 \\
1222\end{array}$ & 13.68 \\
\hline 2361 & 423.5 & $\begin{array}{r}63 \\
122 \\
657\end{array}$ & $\begin{array}{r}2.47 \\
16.70\end{array}$ \\
\hline 2458 & 453.6 & $\begin{array}{r}659 \\
2457 \\
25\end{array}$ & $\begin{array}{l}8.29 \\
8.10\end{array}$ \\
\hline 2459 & 441.0 & $\begin{array}{r}103 \\
2983 \\
83\end{array}$ & $\begin{array}{r}4.76 \\
11.29\end{array}$ \\
\hline 2460 & 431.0 & $\begin{array}{r}312 \\
1271 \\
480\end{array}$ & $\begin{array}{l}0.81 \\
1.55\end{array}$ \\
\hline 2461 & 420.8 & $\begin{array}{r}26 \\
161 \\
826\end{array}$ & $\begin{array}{r}1.66 \\
12.14\end{array}$ \\
\hline
\end{tabular}


TABLE A.3 Cont.

\begin{tabular}{|c|c|c|c|}
\hline Nodal Coordinates & $\begin{array}{l}\text { Surface Elevation } \\
\text { (meters above } \mathrm{ms} \mathrm{l}^{\mathrm{a}} \text { ) }\end{array}$ & $\begin{array}{l}\text { Layer Resistivity } \\
(\Omega-m)\end{array}$ & $\begin{array}{c}\text { Layer Thickness } \\
(\mathbf{m})\end{array}$ \\
\hline 2558 & 450.4 & $\begin{array}{l}139 \\
734\end{array}$ & 11.11 \\
\hline 2559 & 437.8 & $\begin{array}{l}164 \\
600\end{array}$ & 3.85 \\
\hline 2560 & 429.7 & $\begin{array}{r}134 \\
2565 \\
11\end{array}$ & $\begin{array}{r}5.82 \\
14.90\end{array}$ \\
\hline 2655 & 445.7 & $\begin{array}{r}59 \\
505\end{array}$ & 5.62 \\
\hline 2657 & 453.5 & $\begin{array}{r}59 \\
3111\end{array}$ & 8.25 \\
\hline 2658 & 443.5 & $\begin{array}{r}26 \\
942\end{array}$ & 5.12 \\
\hline 2659 & 434.8 & $\begin{array}{r}27 \\
1226\end{array}$ & 6.27 \\
\hline 2660 & 428.1 & $\begin{array}{r}71 \\
465 \\
4679\end{array}$ & $\begin{array}{r}7.28 \\
12.58\end{array}$ \\
\hline 2754 & 440.2 & $\begin{array}{r}29 \\
1648\end{array}$ & 11.52 \\
\hline 2756 & 435.1 & $\begin{array}{r}30 \\
2038\end{array}$ & 10.80 \\
\hline 2758 & 437.4 & $\begin{array}{r}23 \\
687\end{array}$ & 4.96 \\
\hline 2760 & 422.2 & $\begin{array}{r}11 \\
576\end{array}$ & 1.39 \\
\hline 2853 & 436.9 & $\begin{array}{r}29 \\
515\end{array}$ & 6.76 \\
\hline 2854 & 434.9 & $\begin{array}{r}28 \\
71 \\
665\end{array}$ & $\begin{array}{r}3.92 \\
14.05\end{array}$ \\
\hline 2855 & 437.8 & $\begin{array}{r}37 \\
417\end{array}$ & 9.22 \\
\hline
\end{tabular}


TABLE A.3 Cont.

\begin{tabular}{|c|c|c|c|}
\hline Nodal Coordinates & $\begin{array}{l}\text { Surface Elevation } \\
\text { (meters above } \mathrm{ms}^{\mathrm{a}} \text { ) }\end{array}$ & $\begin{array}{l}\text { Layer Resistivity } \\
(\Omega-m)\end{array}$ & $\begin{array}{l}\text { Layer Thickness } \\
\text { (m) }\end{array}$ \\
\hline 2856 & 432.2 & $\begin{array}{r}27 \\
415\end{array}$ & 6.59 \\
\hline 2857 & 433.4 & $\begin{array}{r}36 \\
279\end{array}$ & 5.75 \\
\hline 2858 & 432.4 & $\begin{array}{r}22 \\
561\end{array}$ & 4.91 \\
\hline 2859 & 425.0 & $\begin{array}{r}18 \\
255 \\
5364\end{array}$ & $\begin{array}{r}2.54 \\
33.57\end{array}$ \\
\hline 2953 & 431.5 & $\begin{array}{r}29 \\
109 \\
1364\end{array}$ & $\begin{array}{r}3.89 \\
34.75\end{array}$ \\
\hline 2954 & 430.5 & $\begin{array}{r}33 \\
379\end{array}$ & 8.81 \\
\hline 2955 & 434.8 & $\begin{array}{r}27 \\
472\end{array}$ & 6.17 \\
\hline 2956 & 430.1 & $\begin{array}{r}40 \\
452\end{array}$ & 8.41 \\
\hline 2957 & 430.1 & $\begin{array}{r}18 \\
582\end{array}$ & 6.07 \\
\hline 2958 & 429.2 & $\begin{array}{r}17 \\
2536\end{array}$ & 7.05 \\
\hline 2959 & 421.0 & $\begin{array}{r}29 \\
800\end{array}$ & 5.53 \\
\hline 3054 & 425.5 & $\begin{array}{r}22 \\
90 \\
1565\end{array}$ & $\begin{array}{r}2.13 \\
24.21\end{array}$ \\
\hline 3055 & . 429.6 & $\begin{array}{r}39 \\
488\end{array}$ & 7.91 \\
\hline 3056 & 426.1 & $\begin{array}{l}102 \\
392\end{array}$ & 8.30 \\
\hline 3057 & 422.3 & $\begin{array}{r}92 \\
512\end{array}$ & 13.77 \\
\hline
\end{tabular}


TABLE A.3 Cont.

\begin{tabular}{|c|c|c|c|}
\hline Nodal Coordinates & $\begin{array}{l}\text { Surface Elevation } \\
\text { (meters above } \mathrm{ms}^{\mathrm{a}} \text { ) }\end{array}$ & $\begin{array}{c}\text { Layer Resistivity } \\
(\Omega-\mathrm{m})\end{array}$ & $\begin{array}{l}\text { Layer Thickness } \\
\text { (m) }\end{array}$ \\
\hline 3058 & 426.9 & $\begin{array}{r}26 \\
192 \\
2041\end{array}$ & $\begin{array}{r}5.10 \\
25.18\end{array}$ \\
\hline 3059 & 419.0 & $\begin{array}{r}64 \\
702\end{array}$ & 7.97 \\
\hline 3153 & 426.7 & $\begin{array}{r}56 \\
424\end{array}$ & 9.68 \\
\hline 3154 & 428.6 & $\begin{array}{r}61 \\
313\end{array}$ & 12.15 \\
\hline 3155 & 419.3 & $\begin{array}{r}84 \\
208\end{array}$ & 4.46 \\
\hline 3157 & 419.5 & $\begin{array}{l}111 \\
460\end{array}$ & 8.65 \\
\hline 3158 & 417.9 & $\begin{array}{r}43 \\
571\end{array}$ & 4.39 \\
\hline 3159 & 416.4 & $\begin{array}{r}87 \\
375\end{array}$ & 4.97 \\
\hline 3254 & 423.7 & $\begin{array}{r}46 \\
291\end{array}$ & 6.19 \\
\hline 3255 & 432.3 & $\begin{array}{l}138 \\
699 \\
131\end{array}$ & $\begin{array}{l}2.95 \\
6.72\end{array}$ \\
\hline 3256 & 431.0 & $\begin{array}{r}43 \\
479\end{array}$ & 2.76 \\
\hline 3257 & 420.7 & $\begin{array}{r}361 \\
1146 \\
96\end{array}$ & $\begin{array}{r}7.18 \\
11.86\end{array}$ \\
\hline 3258 . & 411.1 & $\begin{array}{r}6 \\
103,054\end{array}$ & 1.02 \\
\hline 3259 & 403.6 & $\begin{array}{r}20 \\
12,616 \\
33\end{array}$ & $\begin{array}{l}0.43 \\
0.54\end{array}$ \\
\hline
\end{tabular}


TABLE A.3 Cont.

\begin{tabular}{|c|c|c|c|}
\hline Nodal Coordinates & $\begin{array}{l}\text { Surface Elevation } \\
\text { (meters above } \mathrm{ms}^{\mathrm{a}} \text { ) }\end{array}$ & $\begin{array}{c}\text { Layer Resistivity } \\
(\Omega-m)\end{array}$ & $\begin{array}{l}\text { Layer Thickness } \\
(\mathrm{m})\end{array}$ \\
\hline 3354 & 432.1 & $\begin{array}{r}55 \\
2680 \\
107 \\
1319\end{array}$ & $\begin{array}{r}6.13 \\
2.20 \\
36.03\end{array}$ \\
\hline 3355 & 428.8 & $\begin{array}{r}38 \\
427\end{array}$ & 9.70 \\
\hline 3356 & 433.2 & $\begin{array}{r}77 \\
317\end{array}$ & 4.05 \\
\hline 3357 & 425.4 & $\begin{array}{r}28 \\
509\end{array}$ & 6.29 \\
\hline 3358 & 442.0 & $\begin{array}{l}266 \\
417\end{array}$ & 10.73 \\
\hline 3359 & 415.7 & $\begin{array}{l}238 \\
552\end{array}$ & 13.30 \\
\hline 3455 & 442.2 & $\begin{array}{r}24 \\
324\end{array}$ & 6.59 \\
\hline 3457 & 430.4 & $\begin{array}{r}51 \\
362\end{array}$ & 5.19 \\
\hline 3458 & 425.1 & $\begin{array}{r}67 \\
773\end{array}$ & 7.81 \\
\hline 3555 & 442.2 & $\begin{array}{l}158 \\
597\end{array}$ & 14.49 \\
\hline 3557 & 435.2 & $\begin{array}{r}18 \\
485\end{array}$ & 1.56 \\
\hline 3558 & 429.2 & $\begin{array}{r}25 \\
1133\end{array}$ & 4.54 \\
\hline 3657 & 437.3 & $\begin{array}{r}67 \\
5085\end{array}$ & 12.71 \\
\hline 3659 & 438.7 & $\begin{array}{r}154 \\
48 \\
5710\end{array}$ & $\begin{array}{l}5.89 \\
6.21\end{array}$ \\
\hline 3757 & 442.8 & $\begin{array}{l}196 \\
812\end{array}$ & 30.49 \\
\hline
\end{tabular}


TABLE A.3 Cont.

\begin{tabular}{|c|c|c|c|}
\hline Nodal Coordinates & $\begin{array}{l}\text { Surface Elevation } \\
\text { (meters above } \mathrm{ms}^{\mathrm{a}} \text { ) }\end{array}$ & $\begin{array}{l}\text { Layer Resistivity } \\
(\Omega-m)\end{array}$ & $\begin{array}{l}\text { Layer Thickness } \\
\qquad(\mathrm{m})\end{array}$ \\
\hline 3758 & 443.2 & $\begin{array}{r}159 \\
11,068\end{array}$ & 34.06 \\
\hline 3857 & 447.9 & $\begin{array}{r}18 \\
377\end{array}$ & 2.99 \\
\hline 3858 & 442.4 & $\begin{array}{r}41 \\
233\end{array}$ & 7.03 \\
\hline 3956 & 454.9 & $\begin{array}{r}16 \\
403\end{array}$ & 1.47 \\
\hline 3957 & 449.6 & $\begin{array}{r}17 \\
206\end{array}$ & 1.40 \\
\hline 4056 & 458.7 & $\begin{array}{r}58 \\
583\end{array}$ & 4.53 \\
\hline
\end{tabular}

$\mathrm{a}_{\mathrm{msl}}=$ mean sea level. 
TABLE A.4 Results of Inversion of Seismic Refraction Profiling Data

\begin{tabular}{|c|c|c|c|c|c|}
\hline Shot Point & \multicolumn{2}{|c|}{ Coordinates } & $\begin{array}{l}\text { Surface Elevation } \\
\text { (meters above } \mathrm{ms}^{\mathrm{a}} \text { ) }\end{array}$ & $\begin{array}{l}\text { Layer Velocity } \\
\qquad(\mathrm{m} / \mathrm{s})\end{array}$ & $\begin{array}{l}\text { Layer Thickness } \\
(\mathrm{m})\end{array}$ \\
\hline $1029 W$ & 3.00 & 60.01 & & $\begin{array}{r}666 \\
1415\end{array}$ & 9.21 \\
\hline $1030 W$ & 4.00 & 59.00 & 451.8 & $\begin{array}{r}500 \\
1290 \\
1559\end{array}$ & $\begin{array}{l}4.83 \\
6.00\end{array}$ \\
\hline $\begin{array}{c}1031 \mathrm{E} \\
.\end{array}$ & 5.04 & 59.00 & 443.4 & $\begin{array}{r}500 \\
1290 \\
2559\end{array}$ & $\begin{array}{r}4.88 \\
10.75\end{array}$ \\
\hline $1033 E$ & 7.12 & 60.00 & 446.5 & $\begin{array}{r}555 \\
2696\end{array}$ & 5.27 \\
\hline $1034 N$ & 8.00 & 60.01 & 441.0 & $\begin{array}{r}260 \\
693 \\
3092\end{array}$ & $\begin{array}{l}2.05 \\
6.61\end{array}$ \\
\hline $1035 \mathrm{~S}$ & 8.00 & 59.60 & 439.3 & $\begin{array}{r}260 \\
693 \\
3092\end{array}$ & $\begin{array}{l}1.76 \\
9.46\end{array}$ \\
\hline $1036 \mathrm{SE}$ & 10.90 & 59.10 & 447.5 & $\begin{array}{r}416 \\
1536\end{array}$ & 4.24 \\
\hline 1037 NW & 10.50 & 59.60 & 447.2 & $\begin{array}{r}416 \\
1536\end{array}$ & 9.47 \\
\hline $1038 N$ & 2.00 & 59.65 & 483 & $\begin{array}{r}357 \\
1403\end{array}$ & 6.16 \\
\hline $1040 \mathrm{~S}$ & 2.00 & 59.00 & 483.1 & $\begin{array}{r}357 \\
1403\end{array}$ & 2.94 \\
\hline $1041 E$ & 14.00 & 61.96 & 459.1 & $\begin{array}{r}500 \\
1515\end{array}$ & 12.89 \\
\hline $1042 W$ & 13.50 & 61.75 & 463 & $\begin{array}{r}500 \\
1515\end{array}$ & 7.70 \\
\hline $1043 \mathrm{~S}$ & 11.90 & 59.13 & 441.8 & $\begin{array}{r}416 \\
3354\end{array}$ & 6.06 \\
\hline $1044 N$ & 12.00 & 59.65 & 444.0 & $\begin{array}{r}416 \\
3354\end{array}$ & 8.80 \\
\hline
\end{tabular}


TABLE A.4 Cont.

\begin{tabular}{|c|c|c|c|c|c|}
\hline Shot Point & $\mathrm{CoO}$ & nates & $\begin{array}{l}\text { Surface Elevation } \\
\text { (meters above } \mathrm{ms}^{\mathrm{a}} \text { ) }\end{array}$ & $\begin{array}{l}\text { Layer Velocity } \\
\qquad(\mathrm{m} / \mathrm{s})\end{array}$ & $\begin{array}{l}\text { Layer Thickness } \\
(\mathrm{m})\end{array}$ \\
\hline $1045 \mathrm{E}$ & 13.30 & 59.50 & 440.5 & $\begin{array}{r}250 \\
633 \\
1660\end{array}$ & $\begin{array}{r}1.37 \\
11.60\end{array}$ \\
\hline $1046 \mathrm{~W}$ & 12.70 & 59.50 & 442 & $\begin{array}{r}250 \\
633 \\
1660\end{array}$ & $\begin{array}{r}1.63 \\
10.90\end{array}$ \\
\hline $1047 \mathrm{E}$ & 15.35 & 60.00 & 437 & $\begin{array}{r}400 \\
3818\end{array}$ & 11.25 \\
\hline $1048 \mathrm{~W}$ & 14.31 & 60.00 & 440 & $\begin{array}{r}400 \\
3818\end{array}$ & 6.86 \\
\hline $1049 \mathrm{~W}$ & 17.82 & 61.00 & 432 & $\begin{array}{r}600 \\
1514 \\
3713\end{array}$ & $\begin{array}{l}10.64 \\
21.86\end{array}$ \\
\hline $1050 \mathrm{E}$ & 18.85 & 61.00 & 430 & $\begin{array}{r}600 \\
1514 \\
3713\end{array}$ & $\begin{array}{r}9.76 \\
12.76\end{array}$ \\
\hline $1051 \mathrm{~W}$ & 21.02 & 61.00 & 426.2 & $\begin{array}{r}500 \\
1397 \\
3788\end{array}$ & $\begin{array}{r}5.00 \\
15.18\end{array}$ \\
\hline $1052 \mathrm{E}$ & 22.00 & 60.00 & 424.5 & $\begin{array}{r}500 \\
1397 \\
3788\end{array}$ & $\begin{array}{r}6.64 \\
15.02\end{array}$ \\
\hline $1053 \mathrm{E}$ & 24.92 & 61.00 & 419.5 & $\begin{array}{r}400 \\
1968 \\
4115\end{array}$ & $\begin{array}{r}5.19 \\
17.48\end{array}$ \\
\hline $1054 \mathrm{~W}$ & 23.90 & 61.00 & 420.8 & $\begin{array}{r}400 \\
1968 \\
4115\end{array}$ & $\begin{array}{r}7.02 \\
14.49\end{array}$ \\
\hline 1055 NW & 28.00 & 60.40 & 413 & $\begin{array}{r}500 \\
1738 \\
3815\end{array}$ & $\begin{array}{l}7.30 \\
8.71\end{array}$ \\
\hline 1056 SE & 29.00 & 59.80 & 411 & $\begin{array}{r}500 \\
1738 \\
3815\end{array}$ & $\begin{array}{r}4.95 \\
13.45\end{array}$ \\
\hline
\end{tabular}


TABLE A.4 Cont.

\begin{tabular}{|c|c|c|c|c|c|}
\hline Shot Point & \multicolumn{2}{|c|}{ Coordinates } & $\begin{array}{l}\text { Surface Elevation } \\
\text { (meters above } \mathrm{msl}^{\mathrm{a}} \text { ) }\end{array}$ & $\begin{array}{l}\text { Layer Velocity } \\
\qquad(\mathrm{m} / \mathrm{s})\end{array}$ & $\begin{array}{l}\text { Layer Thickness } \\
\qquad(\mathrm{m})\end{array}$ \\
\hline $1057 E$ & 31.40 & 59.80 & 408.6 & $\begin{array}{r}500 \\
1817 \\
4723\end{array}$ & $\begin{array}{r}6.24 \\
13.03\end{array}$ \\
\hline $1058 W$ & 30.40 & 59.80 & 410.0 & $\begin{array}{r}500 \\
1817 \\
4723\end{array}$ & $\begin{array}{l}7.02 \\
9.18\end{array}$ \\
\hline 1059 SE & 31.50 & 57.50 & 410 & $\begin{array}{r}500 \\
1977 \\
4233\end{array}$ & $\begin{array}{r}3.87 \\
18.93\end{array}$ \\
\hline $1060 \mathrm{NW}$ & 31.30 & 58.50 & 410 & $\begin{array}{r}500 \\
1977 \\
4233\end{array}$ & $\begin{array}{r}3.82 \\
21.93\end{array}$ \\
\hline $1061 \mathrm{NE}$ & 31.48 & 53.76 & 427 & $\begin{array}{r}555 \\
1179\end{array}$ & 2.84 \\
\hline $1062 \mathrm{SW}$ & 31.08 & 52.84 & 427 & $\begin{array}{r}555 \\
1179\end{array}$ & 6.80 \\
\hline $1063 \mathrm{~S}$ & 31.14 & 55.14 & 420 & $\begin{array}{r}500 \\
2787\end{array}$ & 6.84 \\
\hline $1064 N$ & 30.60 & 56.08 & 423 & $\begin{array}{r}500 \\
2787\end{array}$ & 6.97 \\
\hline $1067 \mathrm{NE}$ & 31.00 & 49.00 & - & $\begin{array}{r}338 \\
1276\end{array}$ & 5.59 \\
\hline $1068 \mathrm{SW}$ & 30.48 & 48.10 & - & $\begin{array}{r}338 \\
1276\end{array}$ & 6.20 \\
\hline $1069 W$ & 17.00 & 61.96 & 443.5 & $\begin{array}{r}690 \\
3882\end{array}$ & 12.29 \\
\hline $1070 \mathrm{E}$ & 18.05 & 62.00 & 440.8 & $\begin{array}{r}690 \\
3882\end{array}$ & 9.86 \\
\hline $1071 \mathrm{~W}$ & 16.96 & 61.00 & 432.2 & $\begin{array}{r}555 \\
3128\end{array}$ & 8.71 \\
\hline
\end{tabular}


TABLE A.4 Cont.

\begin{tabular}{|c|c|c|c|c|c|}
\hline Shot Point & \multicolumn{2}{|c|}{ Coordinates } & $\begin{array}{l}\text { Surface Elevation } \\
\text { (meters above } \mathrm{ms}^{\mathrm{a}} \text { ) }\end{array}$ & $\begin{array}{l}\text { Layer Velocity } \\
\qquad(\mathrm{m} / \mathrm{s})\end{array}$ & $\begin{array}{l}\text { Layer Thickness } \\
\text { (m) }\end{array}$ \\
\hline $1072 \mathrm{E}$ & 18.00 & 61.00 & 430.3 & $\begin{array}{r}555 \\
3128\end{array}$ & 9.58 \\
\hline $1073 \mathrm{~W}$ & 17.00 & 60.06 & 437.2 & $\begin{array}{r}550 \\
2924\end{array}$ & 6.27 \\
\hline $1074 E$ & 18.00 & 60.00 & 435.3 & $\begin{array}{r}550 \\
2924\end{array}$ & 8.75 \\
\hline $1075 \mathrm{~W}$ & 16.80 & 63.00 & 456.9 & $\begin{array}{r}544 \\
2967\end{array}$ & $9 . \dot{41}$ \\
\hline $1076 \mathrm{E}$ & 17.80 & 63.16 & 456.0 & $\begin{array}{r}544 \\
2967\end{array}$ & 11.05 \\
\hline $1081 \mathrm{E}$ & 18.04 & 59.00 & 444.5 & $\begin{array}{r}652 \\
2044\end{array}$ & 8.55 \\
\hline $1082 W$ & 16.96 & 58.00 & 459.5 & $\begin{array}{r}555 \\
1997\end{array}$ & 5.36 \\
\hline $1083 E$ & 18.00 & 57.98 & 453.0 & $\begin{array}{r}555 \\
1997\end{array}$ & 10.68 \\
\hline $1084 W$ & 33.00 & 54.52 & 431 & $\begin{array}{r}454 \\
1333 \\
3822\end{array}$ & $\begin{array}{r}7: 84 \\
15.26\end{array}$ \\
\hline $1086 \mathrm{E}$ & 26.02 & 60.00 & 428.1 & $\begin{array}{r}666 \\
3902\end{array}$ & 14.43 \\
\hline $1087 W$ & 24.98 & 60.02 & 429.7 & $\begin{array}{r}666 \\
3902\end{array}$ & 11.10 \\
\hline $1088 W$ & 24.97 & 59.02 & 437 & $\begin{array}{r}454 \\
3005\end{array}$ & 8.46 \\
\hline $1089 \mathrm{E}$ & 26.01 & 59.02 & 437 & $\begin{array}{r}454 \\
3005\end{array}$ & 9.11 \\
\hline $1090 W$ & 25.02 & 58.00 & 450.4 & $\begin{array}{r}500 \\
1230 \\
2932\end{array}$ & $\begin{array}{r}4.84 \\
17.88\end{array}$ \\
\hline $1092 \mathrm{E}$ & 26.05 & 58.00 & 443.5 & $\begin{array}{r}500 \\
1230 \\
2932\end{array}$ & $\begin{array}{r}7.43 \\
15.81\end{array}$ \\
\hline
\end{tabular}


TABLE A.4 Cont.

\begin{tabular}{|c|c|c|c|c|c|}
\hline Shot Point & \multicolumn{2}{|c|}{ Coordinates } & $\begin{array}{l}\text { Surface Elevation } \\
\text { (meters above } \mathrm{msl}^{\mathrm{a}} \text { ) }\end{array}$ & $\begin{array}{l}\text { Layer Velocity } \\
\qquad(\mathrm{m} / \mathrm{s})\end{array}$ & $\begin{array}{l}\text { Layer Thickness } \\
\text { (m) }\end{array}$ \\
\hline $1093 E$ & 6.92 & 61.00 & 461 & $\begin{array}{r}750 \\
3159\end{array}$ & 9.05 \\
\hline $1094 W$ & 5.86 & 61.00 & 466 & $\begin{array}{r}750 \\
3159\end{array}$ & 9.70 \\
\hline $1095 \mathrm{~W}$ & 6.02 & 59.00 & 455.9 & $\begin{array}{r}500 \\
1428 \\
3705\end{array}$ & $\begin{array}{r}5.06 \\
14.38\end{array}$ \\
\hline $1096 \mathrm{E}$ & 6.90 & 59.00 & 452.8 & $\begin{array}{r}500 \\
1428 \\
3705\end{array}$ & $\begin{array}{l}2.93 \\
7.41\end{array}$ \\
\hline $1097 W$ & 6.00 & 57.99 & 462.5 & $\begin{array}{r}500 \\
3545\end{array}$ & 6.17 \\
\hline $1098 E$ & 7.00 & 57.92 & 460.9 & $\begin{array}{r}500 \\
3545\end{array}$ & 5.54 \\
\hline $1099 \mathrm{~S}$ & 35.02 & 57.00 & 435.2 & $\begin{array}{r}500 \\
2320\end{array}$ & 6.01 \\
\hline $1100 \mathrm{~N}$ & 35.00 & 58.04 & 429.2 & $\begin{array}{r}500 \\
2320\end{array}$ & 9.58 \\
\hline $1101 \mathrm{~S}$ & 34.02 & 57.00 & 430.4 & $\begin{array}{r}500 \\
1723 \\
3855\end{array}$ & $\begin{array}{r}5.79 \\
16.66\end{array}$ \\
\hline $1102 \mathrm{~N}$ & 34.02 & 58.00 & 425.1 & $\begin{array}{r}500 \\
1723 \\
3855\end{array}$ & $\begin{array}{r}5.74 \\
22.29\end{array}$ \\
\hline $1103 N$ & 33.02 & 58.00 & 422.8 & $\begin{array}{r}677 \\
2968\end{array}$ & 8.46 \\
\hline $1104 \mathrm{~S}$ & 33.00 & 56.98 & 425.4 & $\begin{array}{r}677 \\
2968\end{array}$ & 10.30 \\
\hline $1105 \mathrm{~S}$ & 32.00 & 57.50 & 415 & $\begin{array}{r}633 \\
2716\end{array}$ & 6.62 \\
\hline $1106 \mathrm{~N}$ & 32.00 & 58.50 & 409 & $\begin{array}{r}633 \\
2716\end{array}$ & 7.90 \\
\hline
\end{tabular}


TABLE A.4 Cont.

\begin{tabular}{|c|c|c|c|c|c|}
\hline Shot Point & Coo & inates & $\begin{array}{l}\text { Surface Elevation } \\
\text { (meters above } \mathrm{msl}^{\mathrm{a}} \text { ) }\end{array}$ & $\begin{array}{l}\text { Layer Velocity } \\
\qquad(\mathrm{m} / \mathrm{s})\end{array}$ & $\begin{array}{c}\text { Layer Thickness } \\
(\mathrm{m})\end{array}$ \\
\hline $1107 \mathrm{E}$ & 30.00 & 57.84 & 426.9 & $\begin{array}{r}555 \\
997 \\
3700\end{array}$ & $\begin{array}{r}5.69 \\
13.50\end{array}$ \\
\hline $1108 \mathrm{~W}$ & 28.97 & 58.00 & 429.2 & $\begin{array}{r}555 \\
997 \\
3700\end{array}$ & $\begin{array}{r}4.13 \\
15.50\end{array}$ \\
\hline $1109 \mathrm{E}$ & 30.01 & 59.00 & 419 & $\begin{array}{r}588 \\
2702\end{array}$ & 7.70 \\
\hline $1110 \mathrm{~W}$ & 28.97 & 59.00 & 421 & $\begin{array}{r}588 \\
2702\end{array}$ & 7.42 \\
\hline $1111 \mathrm{E}$ & 28.02 & 59.00 & 425 & $\begin{array}{r}555 \\
1647 \\
6210\end{array}$ & $\begin{array}{r}7.51 \\
19.10\end{array}$ \\
\hline $1112 W$ & 26.98 & 59.00 & 430.7 & $\begin{array}{r}555 \\
1647 \\
6210\end{array}$ & $\begin{array}{r}5.23 \\
24.66\end{array}$ \\
\hline $1113 \mathrm{~W}$ & 27.00 & 58.01 & 437.4 & $\begin{array}{r}555 \\
1514 \\
4364\end{array}$ & $\begin{array}{r}8.06 \\
15.40\end{array}$ \\
\hline $1114 \mathrm{E}$ & 28.02 & 58.00 & 432.4 & $\begin{array}{r}555 \\
1514 \\
4364\end{array}$ & $\begin{array}{r}6.65 \\
21.36\end{array}$ \\
\hline $1115 \mathrm{E}$ & 11.00 & 58.02 & 444.2 & $\begin{array}{r}434 \\
1581 \\
3655\end{array}$ & $\begin{array}{r}5.48 \\
16.97\end{array}$ \\
\hline $1116 \mathrm{~W}$ & 9.96 & 58.00 & 448.4 & $\begin{array}{r}434 \\
1581 \\
3655\end{array}$ & $\begin{array}{r}5.74 \\
16.84\end{array}$ \\
\hline $1117 \mathrm{E}$ & 10.04 & 59.00 & 450.4 & $\begin{array}{r}400 \\
3103\end{array}$ & 5.54 \\
\hline $1118 \mathrm{~W}$ & 9.00 & 58.99 & 451.9 & $\begin{array}{r}400 \\
3103\end{array}$ & 8.61 \\
\hline $1119 \mathrm{~N}$ & 13.00 & 57.03 & 443.3 & $\begin{array}{r}400 \\
3130\end{array}$ & 7.98 \\
\hline
\end{tabular}


TABLE A.4 Cont.

\begin{tabular}{|c|c|c|c|c|c|}
\hline Shot Point & \multicolumn{2}{|c|}{ Coordinates } & $\begin{array}{l}\text { Surface Elevation } \\
\text { (meters above } \mathrm{ms}^{\mathrm{a}} \text { ) }\end{array}$ & $\begin{array}{l}\text { Layer Velocity } \\
\qquad(\mathrm{m} / \mathrm{s})\end{array}$ & $\begin{array}{l}\text { Layer Thickness } \\
\text { (m) }\end{array}$ \\
\hline $1120 \mathrm{~S}$ & 12.98 & 55.99 & 447.3 & $\begin{array}{r}400 \\
3130\end{array}$ & 5.76 \\
\hline $1121 \mathrm{~S}$ & 13.12 & 58.00 & 440.4 & $\begin{array}{r}346 \\
1665 \\
7492\end{array}$ & $\begin{array}{r}4.08 \\
35.73\end{array}$ \\
\hline $1122 N$ & 13.02 & 59.00 & $\begin{array}{c}439 \\
\cdot\end{array}$ & $\begin{array}{r}346 \\
1665 \\
7492\end{array}$ & $\begin{array}{r}8.05 \\
13.39\end{array}$ \\
\hline $1123 \mathrm{~W}$ & 12.60 & 60.32 & 447 & $\begin{array}{r}666 \\
2665\end{array}$ & 6.16 \\
\hline $1124 \mathrm{E}$. & 13.64 & 60.32 & 443 & $\begin{array}{r}666 \\
2665\end{array}$ & 10.41 \\
\hline $1125 \mathrm{~W}$ & 13.01 & 61.00 & 456.7 & $\begin{array}{r}500 \\
1219 \\
3663\end{array}$ & $\begin{array}{r}3.31 \\
20.03\end{array}$ \\
\hline $1126 \mathrm{E}$ & 14.05 & 61.00 & 449.8 & $\begin{array}{r}500 \\
1219 \\
3663\end{array}$ & $\begin{array}{l}6.57 \\
8.72\end{array}$ \\
\hline $1127 \mathrm{E}$ & 12.42 & 61.00 & 464.9 & $\begin{array}{r}588 \\
1574 \\
3491\end{array}$ & $\begin{array}{r}5.67 \\
.15 .42\end{array}$ \\
\hline $1128 W$ & 11.38 & 61.00 & 464.9 & $\begin{array}{r}588 \\
1574 \\
3491\end{array}$ & $\begin{array}{r}3.52 \\
20.84\end{array}$ \\
\hline $1129 \mathrm{~W}$ & 21.98 & 58.98 & 440.6 & $\begin{array}{r}625 \\
1561 \\
5873\end{array}$ & $\begin{array}{r}4.63 \\
29.71\end{array}$ \\
\hline $1130 \mathrm{E}$ & 23.02 & 59.00 & 440.9 & $\begin{array}{r}625 \\
1561 \\
5873\end{array}$ & $\begin{array}{r}5.49 \\
26.99\end{array}$ \\
\hline $1131 E$ & 23.00 & 60.01 & 426.9 & $\begin{array}{r}500 \\
7646\end{array}$ & 13.59 \\
\hline $1132 W$ & 22.03 & 59.98 & 426.6 & $\begin{array}{r}500 \\
1536\end{array}$ & 3.92 \\
\hline
\end{tabular}


TABLE A.4 Cont.

\begin{tabular}{cccccc}
\hline Shot Point & Coordinates & $\begin{array}{c}\text { Surface Elevation } \\
\left(\text { meters above } \mathrm{ms}^{\mathrm{a}}\right)\end{array}$ & $\begin{array}{c}\text { Layer Velocity } \\
(\mathrm{m} / \mathrm{s})\end{array}$ & $\begin{array}{c}\text { Layer Thickness } \\
(\mathrm{m})\end{array}$ \\
\hline \multirow{2}{*}{$1133 \mathrm{~W}$} & 21.99 & 58.00 & 449.2 & 544 & 3.24 \\
& & & & 1256 & 36.08 \\
& & & & 4696 & \\
$1134 \mathrm{E}$ & 23.03 & 58.00 & 451.4 & 544 & 5.68 \\
& & & & 1256 & 20.97 \\
$1135 \mathrm{~N}$ & 21.02 & 58.00 & 435.3 & 4696 & 6.87 \\
& & & & 500 & 9.90 \\
$1136 \mathrm{~S}$ & 21.00 & 57.00 & 432 & 3002 & \\
& & & & 500 & \\
\hline
\end{tabular}

${ }^{\mathrm{a}} \mathrm{msl}=$ mean sea level. 


\section{Appendix B:}

Visualizations of Some of the Results from the Geophysical Surveys in the Lautertal 


\section{Appendix B: Visualizations of Some of the Results from the Geophysical Surveys in the Lautertal}

\section{Introduction}

The figures on the following pages are three-dimensional representations of some of the geophysical data obtained in studies of the Lautertal at Hohenfels, Germany. Each figure is preceded by an explanation of the information portrayed and the color convention used.

\section{Figure B.1}

Figure B.1A shows, in plan view, the locations where electromagnetic readings were made in the Lautertal. These locations correspond to nodes of an orthogonal grid (with nodal spacing of $125 \mathrm{~m}$ ) covering the Lautertal.

Figures B.1B-D show electrical conductivity distributions corresponding to transmitterreceiver spacings of 10,20 , and $40 \mathrm{~m}$, respectively, superimposed on the surface topography of the Lautertal (vertical exaggeration of 10). A conductivity value obtained from a given transmitterreceiver spacing is the weighted average of the conductivities of the rocks from the earth's surface to a depth approximately equal to the transmitter-receiver spacing.

The blue color in Figures B.1B-D corresponds to areas where the near-surface deposits have predominantly high conductivity, with the purple color associated with the highest conductivities. The yellow color corresponds to areas where the near-surface deposits have predominantly low conductivity. The higher conductivity values indicate the presence of 'finegrained, unconsolidated surficial deposits, which are capable of retaining water, and/or coarsegrained alluvium saturated with water. The lower conductivity values indicate the presence of well-drained, coarse alluvium and/or carbonate bedrock. 


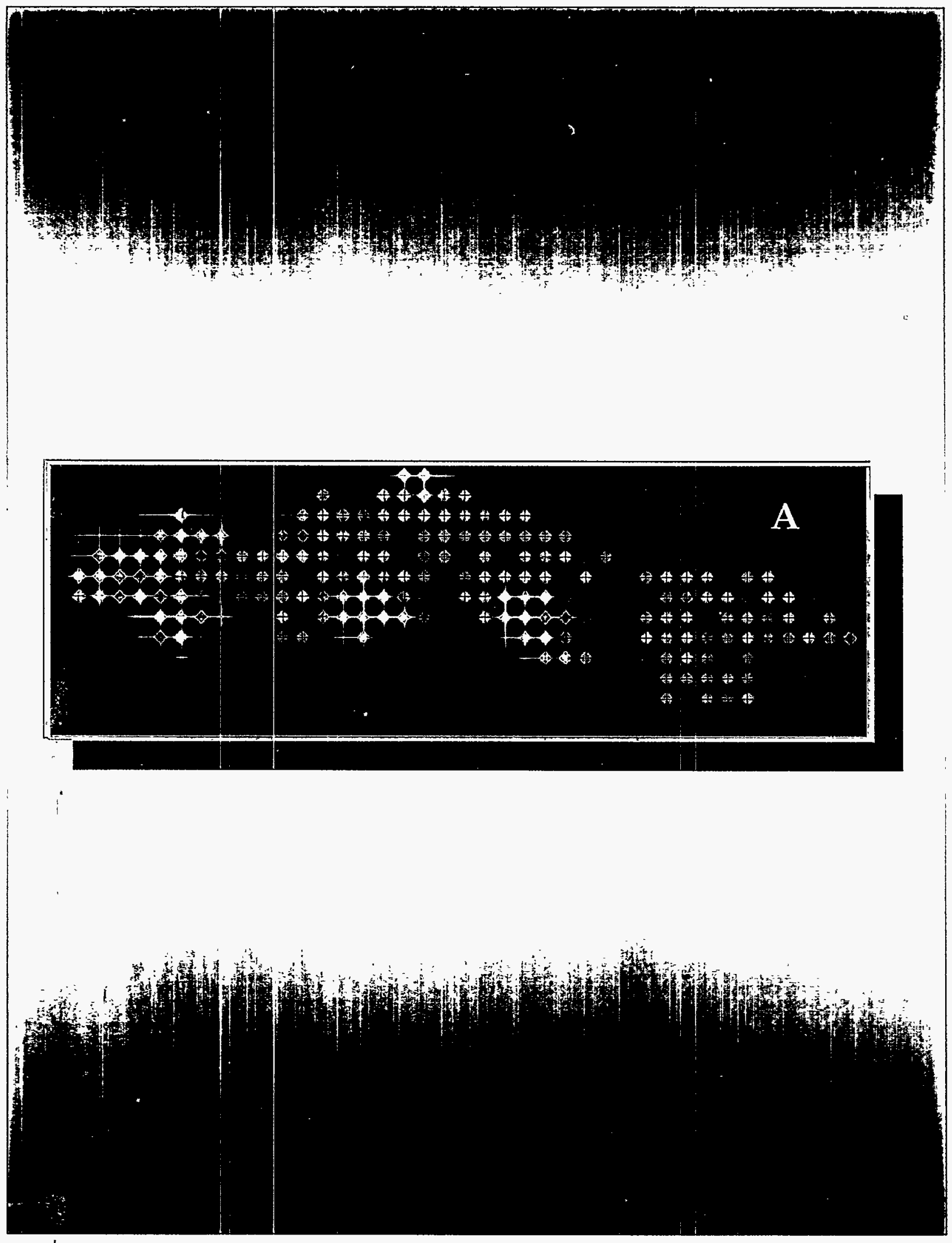

FIGURE B.1 Electrical Conductivity Distributions in the Lautertal as Determined by Electromagnetic Surveying 


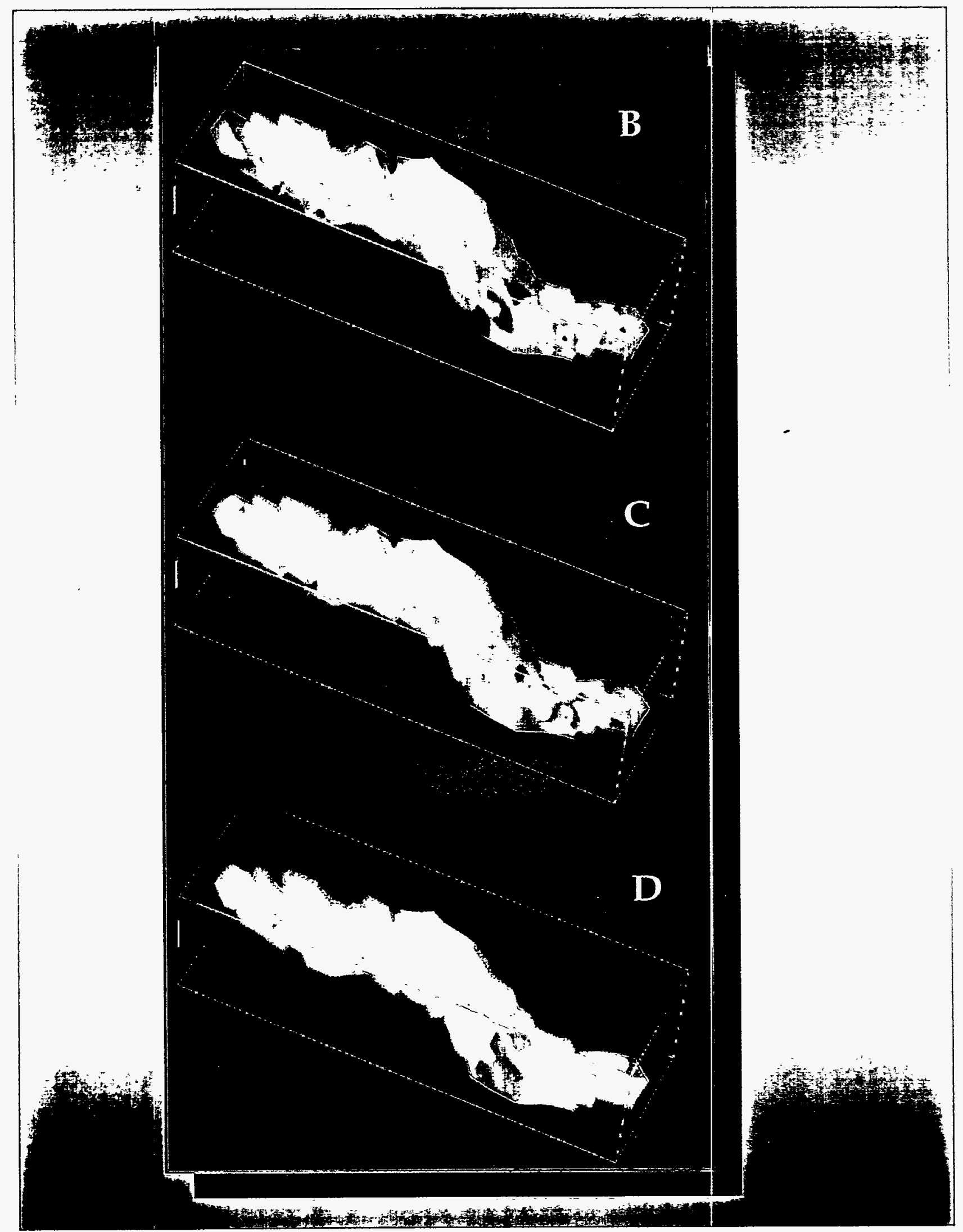

FIGURE B.1 (Cont.) 


\section{Figure B.2}

Figure B.2A shows, in plan view, the locations where vertical electrical soundings were made in the Lautertal. The locations correspond to nodes of an orthogonal grid (with nodal spacing of $125 \mathrm{~m}$ ) covering the Lautertal.

Figure B.2B shows a three-dimensional view (looking to the northwest) of the nearsurface deposits in the Lautertal (vertical exaggeration of 10) based on vertical electrical soundings. The orange dots correspond to the top of the fine-grained, unconsolidated surficial deposits (loam and loess); the yellow dots correspond to the top of the coarse-grained, unconsolidated deposits (alluvium); and the purple dots correspond to the top of the carbonate bedrock. 


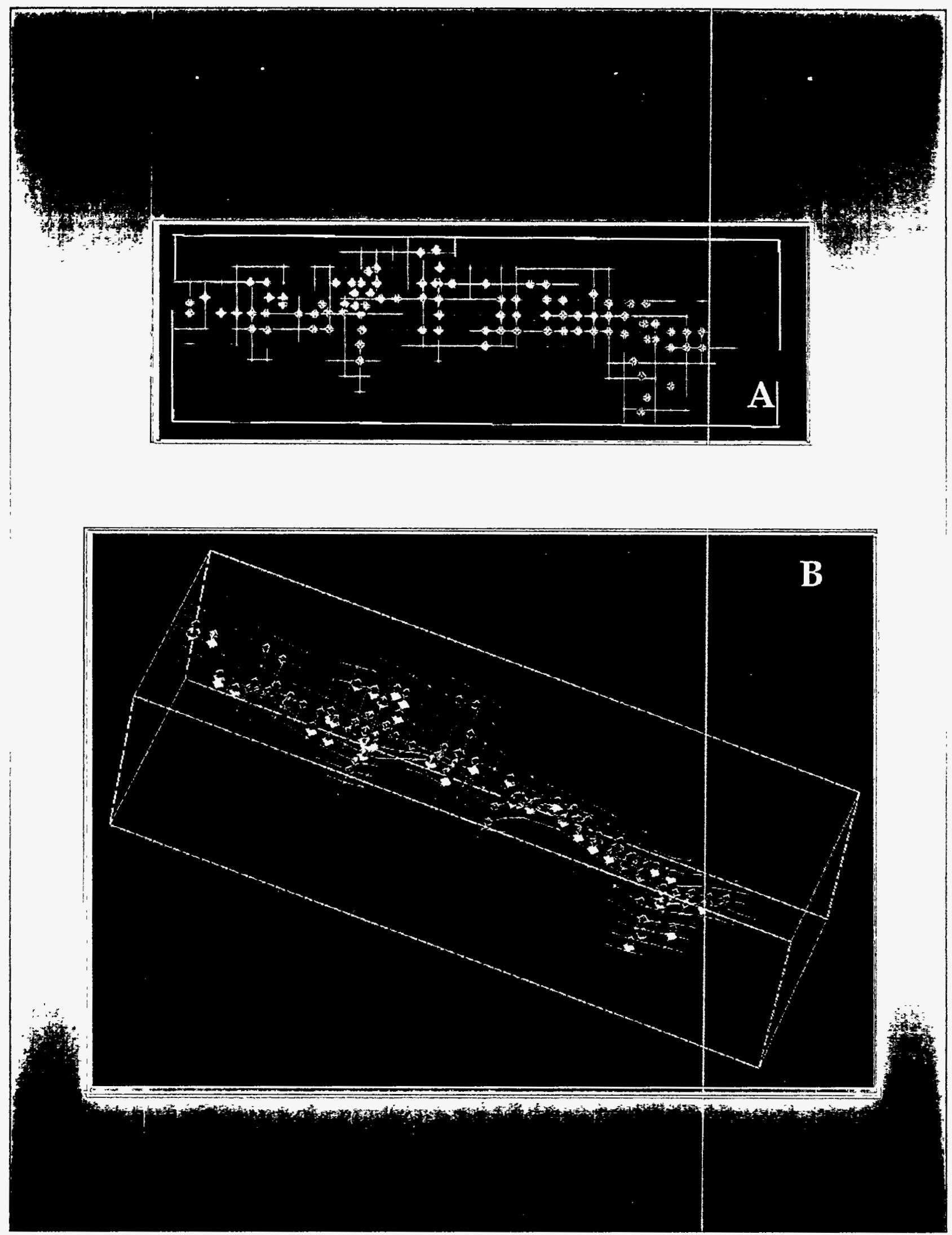

FIGURE B.2 Shallow Geological Framework of the Lautertal as Determined by Vertical Electrical Soundings 
Figure B.3

Figure B.3A shows, in plan view, the locations of the shot points employed in the seismic refraction profiling in the Lautertal and the nature of the deposits immediately below the finegrained, unconsolidated surficial deposits (loam and loess) based on seismic refraction profiling. The yellow color indicates those areas where the loam and loess lie on coarse-grained, unconsolidated deposits (alluvium), and the purple color indicates those areas where the loam and loess lie on the carbonate bedrock.

Figure B.3B shows a three-dimensional view (looking to the northwest) of the surface topography and the base of the loam and loess in the Lautertal (vertical exaggeration of 10). The surface topography is indicated by the shot point locations. The base of the loam and loess is shown in yellow and purple. The color convention is the same as that used in Figure B.3A. 


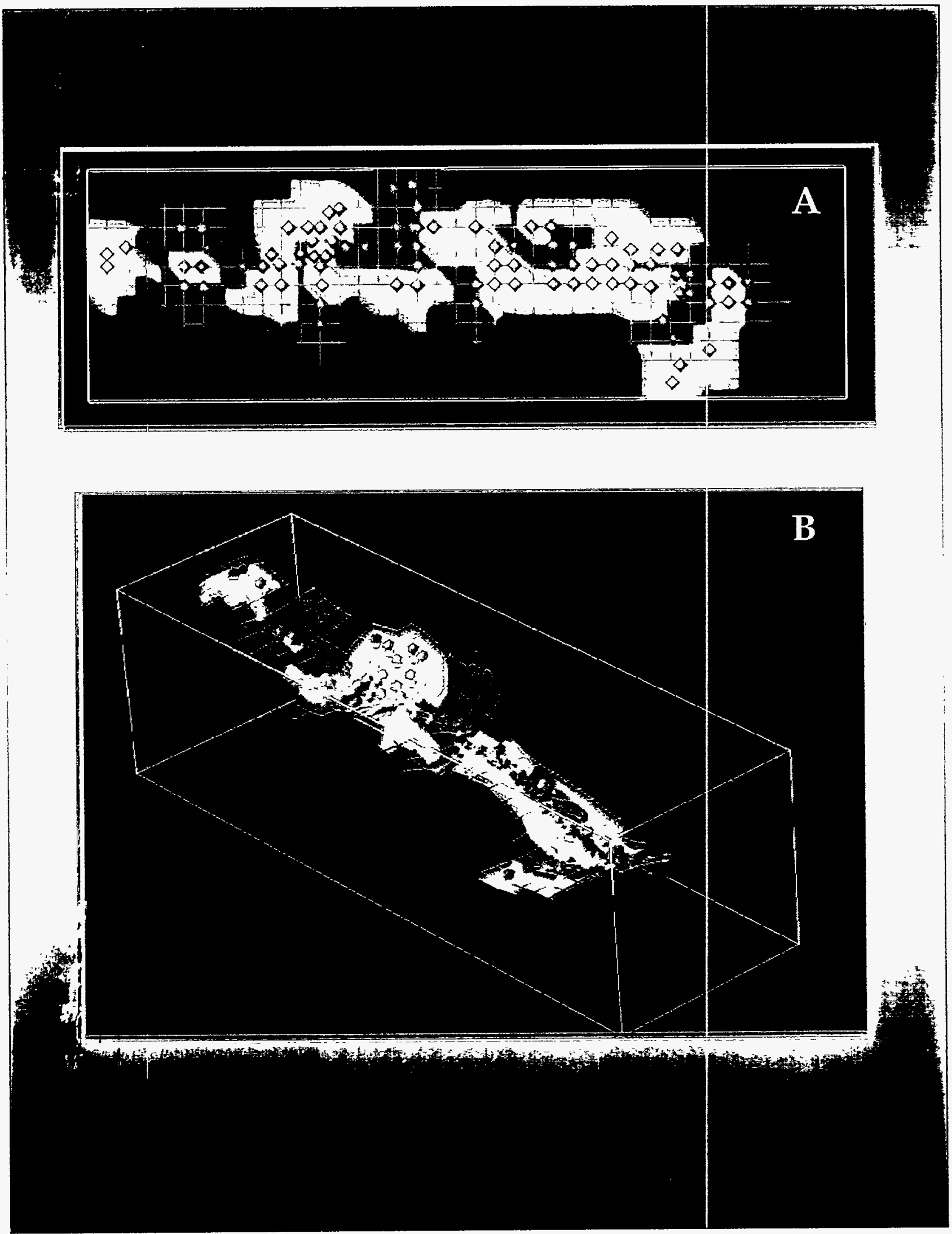

FIGURE B.3 Surface Topography and Base of the Fine-Grained, Unconsolidated Surficial Deposits (Loam and Loess) in the Lautertal 
Figure B.4

Figure B.4A shows, in plan view, the locations of the shot points employed in the seismic refraction profiling in the Lautertal. These locations generally correspond to nodes of an orthogonal grid (with nodal spacing of $125 \mathrm{~m}$ ) covering the Lautertal.

Figure B.4B shows a three-dimensional view (looking to the northwest) of the nearsurface deposits in the Lautertal (vertical exaggeration of 10) based on seismic refraction profiling. The orange dots correspond to the top of the fine-grained, unconsolidated surficial deposits (loam and loess); the yellow dots correspond to the top of the coarse-grained, unconsolidated deposits (alluvium); and the purple dots correspond to the top of the carbonate bedrock. 


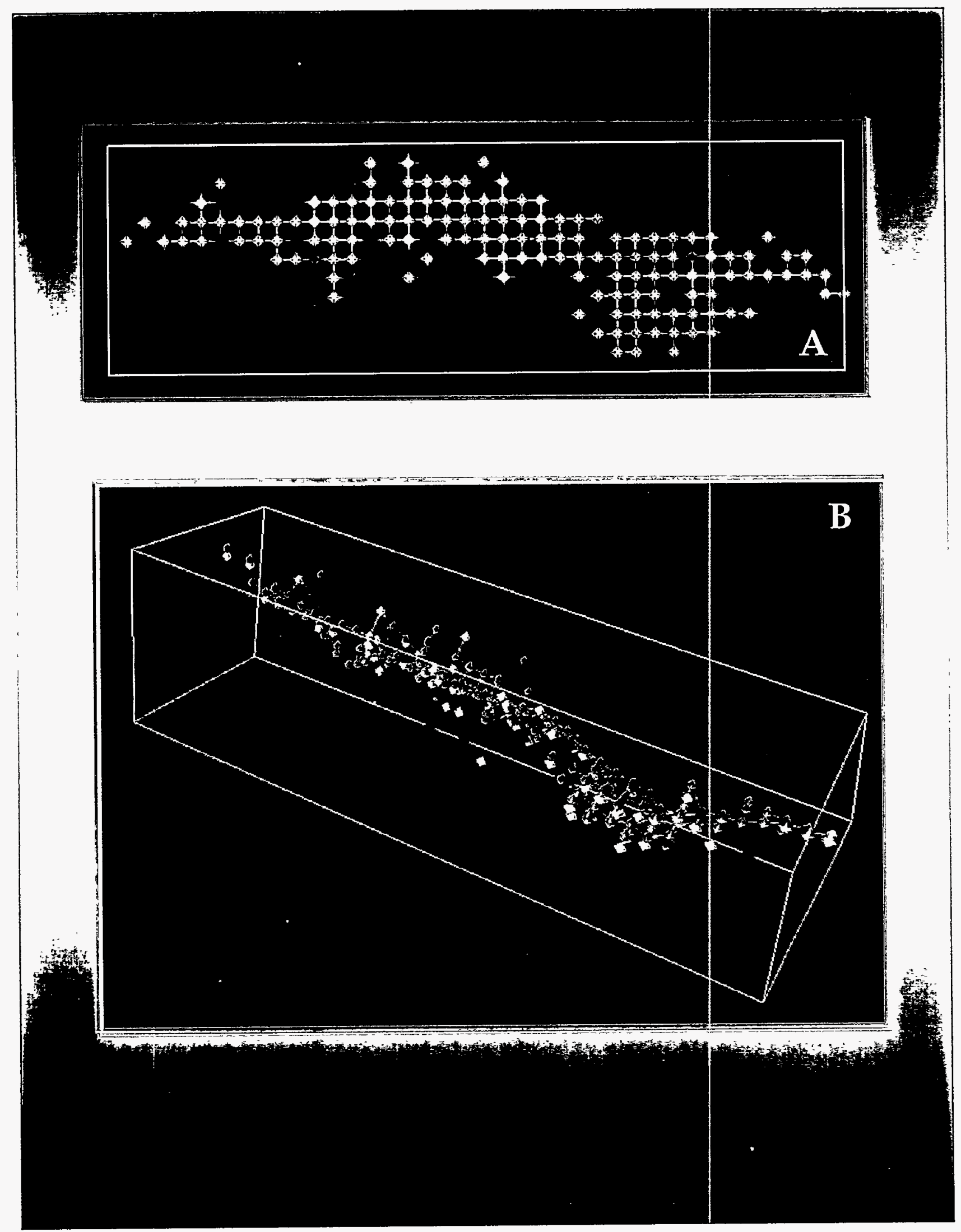

FIGURE B.4 Shallow Geological Framework of the Lautertal as Determined by Seismic Refraction Profiling 